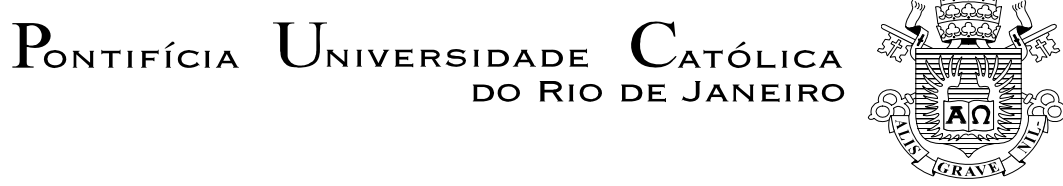

Helen Marques Peixoto

\author{
O Justo e o Legal na Ótica \\ dos Juízes Trabalhistas Fluminenses
}

Dissertação apresentada ao Programa de Pós-graduação em Direito da PUC-Rio como requisito parcial para obtenção do título de Mestre em Direito.

Orientador: Prof. Noel Struchiner Co-orientadora: Rosângela Lunardelli Cavallazzi 


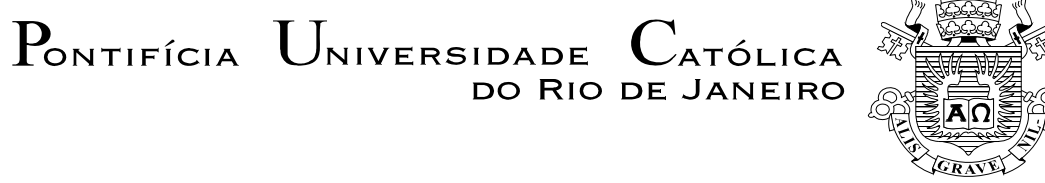

Helen Marques Peixoto

\section{O Justo e o Legal na Ótica dos Juízes Trabalhistas Fluminenses}

Dissertação apresentada ao Programa de Pós-graduação em Direito da PUC-Rio como requisito parcial para obtenção do título de Mestre em Direito. Aprovada pela Comissão Examinadora abaixo assinada:

Prof. Noel Struchiner

Orientador

Departamento de Direito - PUC-Rio

Prof. Rosângela Lunardelli Cavallazzi

Co-orientadora

Departamento de Direito - PUC-Rio

Prof. Sayonara Grillo Coutinho Leonardo da Silva

UFRJ

Prof. Rachel Barros Nigro

Departamento de Direito - PUC-Rio

Profa. Mônica Herz

Vice-Decana de Pós-Graduação do Centro de

Ciências Sociais - PUC-Rio

Rio de Janeiro, 11 de abril de 2014. 
Todos os direitos reservados. É proibida a reprodução total ou parcial do trabalho sem autorização da universidade, da autora e do orientador.

\section{Helen Marques Peixoto}

Graduada em Direito pela Universidade do Estado do Rio de Janeiro (UERJ) em 2003. Aprovada em concurso público para o cargo de analista judiciário - área judiciária - no Tribunal Regional do Trabalho da Primeira Região em 2003. Aprovada em concurso público para o cargo de juíza do trabalho substituta do mesmo tribunal em 2006. Aprovada em curso de especialização em Direito do Trabalho e Processo do Trabalho realizado pela Escola Judicial do referido tribunal em convênio com a Universidade Federal Fluminense. Candidata ao título de Mestre em Direito pela Pontifícia Universidade Católica. Tem como principal área de interesse a filosofia do direito e se dedica principalmente ao estudo da decisão judicial.

Ficha Catalográfica

Peixoto, Helen Marques.

O Justo e o Legal na Ótica dos Juízes Trabalhistas Fluminenses / Helen Marques Peixoto; orientadores: Noel Struchiner. - Rio de Janeiro: PUC-Rio, Departamento de Direito, 2014.

$$
\text { v.; } 115 \text { f. : } 29,7 \mathrm{~cm}
$$

Dissertação (mestrado) - Pontifícia Universidade Católica do Rio de Janeiro. Departamento de Direito.

Inclui referências bibliográficas

1. Direito - Teses. 2. Sobreinclusão e Subinclusão. 3.. Formalismo e Particularismo. 4. Argumentação Jurídica. 5.. Decisão Judicial. I. Struchiner, Noel. Cavallazzi, Rosângela Lunardelli. II. Pontifícia Universidade Católica do Rio de Janeiro. Departamento de Direito. III. Título. 


\section{Agradecimentos}

A Deus, porque tem me cercado de pessoas muito especiais.

A meus pais e a Juli, por todo apoio e carinho, sempre incondicionais.

Às minhas lindas Helena, Mariana, Marília e Amanda, pelo sorriso sempre presente.

À Karina, porque me brinda todos os dias com sua alegria de irmã e à Ingrid, Maria Lúcia e Rossana, que sabem o quanto tenho a agradecê-las.

À Rosângela, minha querida orientadora de longa data, que me ensinou com maestria os primeiros passos na pesquisa e continua me acolhendo como sua sempre fiel aluna e amiga.

Ao Noel, que como brilhante professor e orientador me ensinou muito sobre Teoria do Direito e me fez revisitar todas as minhas crenças antigas, para questioná-las e repensá-las.

À Sayonara, pelo exemplo de pessoa, professora e juíza, sempre encontrando tempo para ajudar com bibliografia, livros e ideias.

À Rachel Nigro, pelo importante aprendizado durante o curso de mestrado, discussões e sugestões de título para a dissertação.

A Sonia Gomes e José Nascimento, cuja ajuda foi essencial para que pudesse cursar o mestrado.

Ao Tribunal Regional do Trabalho da Primeira Região e AMATRA1, pelo apoio concedido.

A Lucas Miotto e Cláudio Oliveira, pela especial ajuda não só na dissertação, mas em todo o curso de mestrado.

A Bárbara, Diana, Jorge Lucas, Milena e Perissè, pelas conversas, sugestões, apoio e pela amizade.

A Elen, Elisa, Mariella, Patrícia e Janice, pela acolhida nos momentos mais difíceis.

Aos novos amigos que fiz na PUC, em especial Danilo Almeida, Deo Campos, Lívia Ferreira, Marcelo Brando, Pedro Chrismann, Rodrigo Tavares, Zeneida Girão, pelas discussões teóricas e por toda ajuda.

Aos meus colegas de magistratura, pelo apoio e participação na minha pesquisa. Serei sempre muito grata.

Aos servidores da $17^{\mathrm{a}} \mathrm{VT} / \mathrm{RJ}$ e $45^{\mathrm{a}} \mathrm{VT} / \mathrm{RJ}$, pelo importante apoio, e aos servidores da $47^{\mathrm{a}} \mathrm{VT} / \mathrm{RJ}$, minha segunda casa atualmente, por todas as ideias e discussões. 


\section{Resumo}

Peixoto, Helen Marques; Struchiner, Noel. O Justo e o Legal na Ótica dos Juízes Trabalhistas Fluminenses. Rio de Janeiro, 2014. 115p. Dissertação de Mestrado - Departamento de Direito, Pontifícia Universidade Católica do Rio de Janeiro.

Quando da aplicação de uma regra legal chega-se a um resultado injusto, será que os juízes estão dispostos a superá-la para aplicar aquilo que entendem como justo? É na compreensão desse problema que se centra esse estudo. A característica de generalidade das regras faz com que abarquem mais casos do que deveriam ou menos, gerando, respectivamente, a sobreinclusão e a subinclusão (Schauer, 1991). Em tais situações, põe-se a questão do que, em geral, prevalece: a aplicação da regra ou sua superação de modo a garantir a justiça do resultado, com a consecução da finalidade subjacente à norma. O desenvolvimento da pesquisa considerou a literatura que demonstra o seguinte fato: há experimentos realizados com cidadãos e advogados que indicam que, para produzir um resultado justo, a desobediência à regra legal é aceita e considerada recomendável (Schweitzer e outros, 2009). Esses experimentos concluíram, ainda, que as respostas tendem a ser substancialmente distintas se a pergunta é realizada em abstrato ou se feita em concreto, no que se convencionou chamar paradoxo abstrato/concreto (Mandelbaum e outros, 2012). Com o intuito de apreender se o mesmo ocorre com os magistrados, adotou-se a metodologia de escolha de um caso referência, aplicando-se questionário aos juízes da primeira instância do Tribunal Regional do Trabalho da Primeira Região (Rio de Janeiro). Os resultados foram semelhantes aos dos experimentos realizados com os jurisdicionados. O estudo demonstrou que prevalece a justiça do resultado em situações de sobreinclusão e subinclusão, havendo, ainda, uma diferença significativa nas respostas quando a pergunta é realizada em abstrato, confirmando o paradoxo abstrato/concreto, visto que os magistrados, nesse caso, foram consideravelmente mais formalistas que em concreto.

\section{Palavras-chave}

Sobreinclusão; subinclusão; formalismo; particularismo; argumentação jurídica; decisão judicial. 


\section{Abstract}

Peixoto, Helen Marques; Struchiner, Noel (Advisor). Fairness and Legality in the Perspective of Rio de Janeiro Labor Judges. Rio de Janeiro, 2014. 115p. MSc Dissertation - Departamento de Direito, Pontifícia Universidade Católica do Rio de Janeiro.

There are cases in which the application of a legal rule causes injustices. In such cases, are judges willing to disregard rules and make decisions based on what they think is fair? This is the main problem this work deals with. Rules are often general, and one of the consequences of their generality is that they encompass more cases than they should. When they encompass more cases, there is the phenomenon of over-inclusiveness, and when they encompass less, there is under-inclusiveness (Schauer 1991). Such phenomena illustrates some circumstances in which judges will face the dilemma of disregarding legal rules or not in favor of the persecution of fairer outcomes. Experiments conducted on citizens and lawyers indicate that the disobedience of a legal rule was accepted and considered commendable in order to achieve a fair outcome (Schweitzer and others, 2009). Besides, it was perceived that the answers tended to be substantially different when formulated in abstract or in concrete; which was called “abstract/concrete paradox" (Mandelbaum and others, 2012). Aiming to understand whether the same happens with judges, a reference case was chosen and a poll applied to the judges of the first instance of the Regional Labor Court of the First Region (Rio de Janeiro). The results were similar to those of the referred experiments.

\section{Keywords}

Under-inclusiveness; over-inclusiveness; formalism; particularism; judicial review. 


\section{Sumário}

$\begin{array}{ll}\text { 1. Introdução } & 10\end{array}$

2. Estado de Direito 17

2.1. Concepções Formais do Estado de Direito 19

2.2. Concepções Substantivas do Estado de Direito 23

2.3. O Estado do Bem-estar Social e o Governo de Juízes e
Advogados

2.4. Implicações Antidemocráticas da Concepção Substantiva
de Estado de Direito

2.5. Manifestações do Estado de Direito no Mundo e Uso da
Expressão

2.6. Observações Finais $\quad 38$

3. Decisão Judicial $\quad 47$

3.1. Tipo de Argumentação Utilizada 48

3.2. O Realismo Jurídico 54

3.3. Críticas ao Realismo e ao Formalismo 56

3.4. Entendendo a Tomada de Decisão 61

3.4.1. O Sentido e o Alcance do Dispositivo Legal e a Determinação dos Fatos Relevantes $\quad 62$

3.4.2. O Papel dos Princípios na Atividade de Interpretação 64

3.4.3. O Conflito entre Normas Jurídicas Igualmente Aplicáveis 65

3.4.4. Ainda no Conflito de Normas: Quando a Parte de um
Processo Agrega Razões de Substância

3.5. Subinclusão e Sobreinclusão $\quad 70$

4. O Legal e o Justo 75

4.1. O Estado de Direito sob a Perspectiva do Jurisdicionado:
uma Análise Empírica

4.2. O Estado de Direito e a Prática Decisória: Análise Empírica do Caso Referência Primeira Instância do Tribunal Regional do

Trabalho da Primeira Região

4.2.1. Experimentos em Ética: o Paradoxo Abstrato/Concreto 81

4.2.2. O Justo e o Legal na Ótica dos Juízes Trabalhistas

Fluminenses

4.2.2.1. Visão Geral e Método

4.2.2.2. Dados e Resultados $\quad 91$

4.2.2.3. Observações Finais 96

$\begin{array}{ll}\text { 5. Conclusão } & 101\end{array}$

$\begin{array}{ll}\text { 6. Referências Bibliográficas } & 105\end{array}$

7. Apêndices 111 


\section{Lista de Tabelas e Figuras}

Figura 1 - Demonstração Gráfica Quanto à Incidência das Respostas dos Juízes na Questão Abstrata

Figura 2 - Demonstração Gráfica Quanto à Incidência das Respostas dos Juízes na Questão Concreta - Prova llícita

Figura 3 - Demonstração Gráfica Quanto à Incidência das Respostas dos Juízes na Questão Concreta - Revelia

Figura 4 - Quadro Comparativo das Questões Concretas e Abstrata Segundo os Critérios de Razões Morais ou Jurídicas 


\section{1 \\ Introdução}

Em 2001, foi publicada uma pesquisa referente a um júri simulado ${ }^{1}$ sobre o seguinte caso: um jovem casal havia sido morto durante um roubo. Um informante deu uma dica que levou o detetive do caso a um suspeito, primo das vítimas, o qual havia cumprido pena anterior por roubo. Certo de que o suspeito era culpado, o detetive conseguiu um mandado para busca em sua residência, encontrando itens que provavelmente estavam relacionados com o crime investigado. Narrado o caso, a pesquisa utilizou algumas alternativas: para alguns dos participantes era informado que o detetive utilizou meios ilegais para conseguir o mandado. Também era informado, para determinados participantes, se o suspeito era de fato o autor do ilícito penal.

O estudo concluiu que, em geral, as pessoas demonstram preferência pelo veredito "correto", justo (um réu inocente sendo absolvido e um culpado sendo condenado), se comparado ao fato de ser observada a validade ou não da prova. Só quando não se tinha conhecimento da real culpa do acusado é que as regras procedimentais acabavam sendo a base do julgamento considerado apropriado.

Em que pese o estudo tenha focado num caso criminal, há questões semelhantes na Justiça do Trabalho. Em 28 de outubro de 2004, o Tribunal Superior do Trabalho noticiou, em sua página na internet ${ }^{2}$, uma decisão que estabelecia que, embora houvesse prova dos fatos alegados pela empresa como ensejadores de uma justa causa, a prova era ilícita, porque partia de uma gravação telefônica autorizada pelo juízo criminal apenas para fins penais e com relação a outras pessoas suspeitas do crime. Logo, não poderia ser confirmada a justa causa objeto da reclamação trabalhista.

Em 22 de março de 2004, o mesmo tribunal informou que, embora houvesse

\footnotetext{
${ }^{1}$ SKITKA, Linda e HOUSTON, David. When due process is of no consequence: Moral mandates and presumed defendant guilt or innocence. 14 (3) Soc. Just. Res. 305 (2001). Disponível em <http://link.springer.com/article/10.1023\%2FA\%3A1014372008257>. Acessado em 03.02.2014.

${ }^{2}$ Disponível

em $<$ http://www.tst.jus.br/busca-denoticias?p_p id=buscanoticia WAR buscanoticiasportlet_INSTANCE xI8Y\&p_p_lifecycle $=$ 0 \&p_p_state $=$ normal\&p_p_mode $=$ view\&p_p_col id $=$ column-

2\&p_p_col_count $=2 \% 20 \&$ advanced-searchdisplay=yes $\% 20 \&$ articleId $=248036 \% 20 \&$ version $=1.0 \% 20 \&$ groupId $=10157 \% 20 \&$ entryClassP $\mathrm{K}=248038>$ Acessado em 21.05.2013
} 
prova de que o ex-empregador, ao dar referências do ex-empregado, dizia que ele era preguiçoso, desobediente e perigoso, essa prova era ilícita e não poderia ser utilizada a fim de se condenar o patrão à indenização por danos morais. Tratava-se de uma gravação telefônica entre o ex-empregador e um terceiro, interceptada pelo ex-empregado ${ }^{3}$.

Tanto os casos reais como o júri simulado ilustram como a aplicação de uma regra $^{4}$ - a da proibição de prova ilícita - acaba por gerar resultados, ao menos em algumas situações, injustos. Sabe-se que o fato ocorreu, mas a prova que se tem dele não é admitida pela ordem jurídica. Evidencia-se, dentre outras tensões existentes nesses exemplos ${ }^{5}$, aquela referente à estabelecida entre a segurança jurídica e a justiça da decisão ${ }^{6}$.

Diante disso, indaga-se: será que os juízes estão dispostos a superar a regra para aplicar aquilo que entendem como justo? E, ainda, será que as respostas judiciais a essa questão, formulada em abstrato, são as mesmas que aquelas apresentadas pelos magistrados quando estes são postos diante de uma situação concreta que envolva o conflito entre o justo e o legal? É na análise desses

\footnotetext{
${ }^{3}$ Disponível $\quad$ em_l $\quad<$ http://www.tst.jus.br/busca-denoticias?p_p_id=buscanoticia_WAR buscanoticiasportlet_INSTANCE xI8Y\&p_p_lifecycle $=$ 0 \&p_p_state $=$ normal \&p_p_mode $=$ view\&p_p_col_id $=$ column$2 \& p \_p \_$col count $=2 \% 20 \&$ advanced-searchdisplay=yes\%20\&articleId=239972\%20\&version=1.0\%20\&groupId=10157\%20\&entryClassP $\mathrm{K}=239974>$ Acessado em 21.05.2013.

${ }^{4} \mathrm{O}$ termo "regra" é utilizado no presente estudo, em termos gerais, no sentido de normas imediatamente descritivas, que se diferem dos princípios por serem estes imediatamente finalísticos e, ainda, vagos. As regras descrevem, pois, comportamentos, enquanto que os princípios dizem respeito a um estado de coisas a ser buscado. Alargamos um pouco o conceito para os fins dessa pesquisa, já que consideramos também como regra não só os atos emanados do Legislativo, como também os entendimentos que estão consolidados pelos Tribunais Superiores, em jurisprudência que delimita o sentido e alcance de enunciados legais, como no caso do conceito de prova ilícita.

${ }^{5}$ É certo que as regras possuem, em geral, uma justificação. A da proibição da prova ilícita, por exemplo, está voltada à garantia da privacidade, de que as ligações telefônicas não serão interceptadas sem autorização judicial e de que a residência de ninguém será violada sem uma ordem judicial obtida por meios lícitos. Neste sentido, também se poderia identificar uma tensão entre tal justificação e a busca da verdade real nos casos apresentados. Mas o que nos interessa, para os fins desse estudo, é a tensão estabelecida entre a aplicação da lei, dentre outras razões porque provém de uma autoridade competente e gera expectativas legítimas (segurança jurídica), e a justiça do resultado (por exemplo, condenar um réu culpado e absolver um inocente).
}

${ }^{6}$ Observe-se que há quem identifique a aplicação da lei com a justiça da decisão, como os positivistas ideológicos. Esse estudo, porém, utilizará as expressões como distintas, com a aplicação da regra jurídica nem sempre coincidindo com a justiça do resultado. Para entender mais a respeito do positivismo ideológico, ver STRUCHINER, Noel. Algumas 'proposições fulcrais' acerca do direito: o debate jusnaturalismo vs. juspositivismo. In Perspectivas atuais da filosofia do direito. Antonio Cavalcanti Maia, Carolina de Campos Melo, Gisele Cittadino, Thamy Pogrebinschi organizadores. Rio de Janeiro: Lumen Iuris, 2005, p. 406. 
problemas que está centrado o presente estudo.

As situações acima narradas indicam que a postura do cidadão frente ao conflito ora apresentado é uma e a do Judiciário Trabalhista outra, vez que o primeiro deu preferência ao resultado justo, enquanto que o Tribunal Superior do Trabalho, ao menos nos casos narrados, optou pela aplicação da regra legal. Para confirmar ou rechaçar essa hipótese, de que o Judiciário tende a optar pelo legal em detrimento do justo, foi realizada uma pesquisa empírica, selecionando-se como caso referência a primeira instância do Tribunal Regional do Trabalho da Primeira Região, com aplicação de questionário aos juízes, explorando, além da questão abstrata, também a concreta.

Note-se que a pesquisa está centrada especificamente naqueles casos em que a lei diz mais do que deveria ou menos, de modo que de sua incidência não se alcançam as consequências desejadas quando de sua edição - no que é chamado de sobreinclusão e subinclusão ${ }^{7}$. Há, portanto, uma regra diretamente aplicável à determinada situação, mas dessa subsunção não resulta uma solução justa. Sendo assim, a investigação do legal e do justo na ótica dos juízes trabalhistas fluminenses tem um âmbito específico, que é estudar a perspectiva desses magistrados em casos de sobreinclusão e subinclusão, quando a aplicação da regra não conduz à justiça, tanto em abstrato como em concreto.

Observe-se que não se entra na discussão das teorias sobre justiça, sendo importante apenas que haja uma distinção entre justiça e legalidade. Para aqueles que reduzem o justo ao legal (como os positivistas ideológicos ${ }^{8}$ ) ou o legal ao justo (como os jusnaturalistas ${ }^{9}$ ) essa distinção não existe e, sendo assim, não haveria que se falar em uma ou outra opção por parte dos magistrados. A relevância da pesquisa está, portanto, atrelada àqueles que entendem que os

\footnotetext{
${ }^{7}$ SCHAUER, Frederick. Playing by the rules: a philosopical examination of rule-based decision-making in law and in life. Oxford: Clarendon Press, 2002, pp. 31-34. A esse respeito, ver também STRUCHINER, Noel. O direito como um campo de escolhas: por uma leitura das regras prescritivas como relações. In Nas fronteiras do formalismo: a função social da dogmática jurídica hoje. RODRIGUES, José Rodrigo; DA SILVA E COSTA, Carlos Eduardo Batalha e BARBOSA, Samuel Rodrigues, organizadores. Rio de Janeiro: Editora Saraiva, 2009, p. 109.

${ }^{8}$ STRUCHINER, Noel. Algumas 'proposições fulcrais' acerca do direito: o debate jusnaturalismo vs. juspositivismo. In Perspectivas atuais da filosofia do direito. Antonio Cavalcanti Maia, Carolina de Campos Melo, Gisele Cittadino, Thamy Pogrebinschi organizadores. Rio de Janeiro: Lumen Iuris, 2005, p. 406.

${ }^{9}$ Idem, p. 405.
} 
conceitos são diferentes. Buscou-se utilizar alguns casos comuns em que há uma certa concepção compartilhada de justiça ou então a própria visão do juiz do que seria justo, extraída da fundamentação que este utiliza para proferir a decisão.

Antes de analisar os dados obtidos com a pesquisa de campo, alguns conceitos precisam ser fixados. Desse modo, trataremos inicialmente das concepções formais e substantivas a respeito do Estado de Direito, porque a pesquisa empírica inspirou-se num experimento realizado por Schweitzer e outros $^{10}$, utilizando-se uma metodologia experimental que remete aos estudos empíricos de Knobe e outros ${ }^{11}$. O estudo de Schweitzer, descrito no terceiro capítulo, versou sobre a tensão entre justiça do resultado e aplicação da regra para os cidadãos não integrantes do Judiciário, utilizando como base da discussão o conceito de Estado de Direito.

Constatou-se que, dependendo do conceito que se adote, tem-se uma propensão à defesa de uma ou outra prática decisória, ou tendente à justiça do resultado ou tendente à observância da regra independente de seu conteúdo. Desse modo, investigar o conceito é importante para também compreender os resultados obtidos nos experimentos realizados com cidadãos, embora o objetivo deste trabalho não seja aprofundar o estudo das formulações teóricas sobre o instituto.

Além desse estudo, também foi importante analisar algumas teorias a respeito da decisão judicial, dado que o nosso propósito é justamente de entender a perspectiva da magistratura no caso específico da sobreinclusão e subinclusão, tanto em abstrato como em concreto. Assim, iniciou-se com a distinção conceitual que separa os argumentos jurídicos dos morais, dada a relação entre eles e o tipo de resultado que se persegue: o legal ou o justo. Dedicou-se, portanto, uma seção a essa análise, especialmente tendo em vista o emprego dos referidos argumentos nas decisões judiciais.

\footnotetext{
${ }^{10}$ SCHWEITZER, N. J.; SYLVESTER, Douglas J. e SAKS, Michael J. Rule violations and the rule of law: a factorial survey of public attitudes. Disponível em $<$ http://papers.ssrn.com/sol3/papers.cfm?abstract id=951005 $>$. Acessado em 28.02.2013. SCHWEITZER, N. J.; SAKS, Michael J. e LOVIS-MCMAHON, David. Is the rule of law a law of rules? Judgments of rule of law violations. Disponível em $<$ http://papers.ssrn.com/sol3/papers.cfm?abstract_id=1439055 $>$. Acessado em 28.02.2013.

${ }^{11} \mathrm{KNOBE}$, Joshua \& DORIS, John M. Strawsonian variations: folk morality and the search for a unified theory. In The handbook of moral psichology. Oxford: Oxford University Press, 2007. Disponível em <http://www.unc.edu/ knobe/Knobe-Doris.pdf >. Acessado em: 04.03.2013.
} 
Ainda a respeito das decisões judiciais, foi analisado o realismo jurídico, já que, caso de fato as soluções judiciais dos litígios sejam embasadas somente nas preferências pessoais dos juízes, como propõe essa teoria, a pesquisa também perde sua razão de ser, visto que fatores extrajurídicos determinariam sempre o resultado do julgamento. Por isso, passou-se à crítica de Hart a essa concepção, permitindo-se que se partisse da premissa de que há áreas em que a escolha do juiz é inevitável, chamadas de “textura aberta” pelo autor, mas também há áreas em que há um conjunto de regras definido e que permite que as pessoas ajam e planejem suas vidas de acordo, dado que os juízes também decidem, em geral, com base nessas regras.

Vista tal crítica, que não se endereçou apenas ao realismo jurídico, mas também ao formalismo ${ }^{12}$, observou-se que são muitos os casos que, na Justiça do Trabalho, exigem a utilização de argumentos de substância; áreas de "textura aberta”. E mesmo nesse contexto de ampla utilização de fatores extralegais na solução das lides, não se pode deixar de reconhecer que há um conjunto de regras estabelecidas que fazem com que empregadores e empregados continuem celebrando contratos, muitas vezes sem se socorrer da via judicial. Quando uma dessas regras gera um resultado injusto em determinado caso concreto, em razão da característica da sobreinclusão e subinclusão, a questão é de se entender para qual extremo pendem os magistrados trabalhistas fluminenses: o do formalismo ou o do particularismo; do legal ou do justo. Os conceitos de formalismo e particularismo foram, portanto, também investigados.

Em 2005, uma pesquisa realizada pela AMB (Associação dos Magistrados Brasileiros), da qual participaram juízes de todo o Brasil, concluiu que a extensa maioria (86,5\%) considera que as decisões judiciais devem orientar-se por parâmetros legais. Por outro lado, mais de 3/4 (78,5\%) dos juízes julgam que se deve ter compromisso com as consequências sociais, o que evidencia que, segundo os magistrados participantes, o compromisso com essas consequências não exclui aquele com os parâmetros legais ou se confunde com eles, na ideia de que o legal se reduz ao justo ou de que o justo se reduz ao legal. Quanto às

\footnotetext{
${ }^{12}$ A crítica de Hart é endereçada ao formalismo como conceituado no capítulo 3, p. 51. Esse formalismo não se confunde com aquele defendido por Schauer e Struchiner, como se verá no capítulo 3, p. 68. Somente este último é levado em consideração para analisar os resultados do experimento realizado com juízes e descrito no último capítulo.
} 
consequências econômicas, responderam a favor de sua consideração nas decisões $36,5 \%$ dos magistrados. ${ }^{13}$

Embora essa pesquisa permita traçar alguns parâmetros, indicando a prevalência dos parâmetros legais na ótica dos magistrados, ela não responde a questão principal ora analisada, visto que não trata especificamente de casos claros cuja incidência da regra legal gere um resultado injusto (sobreinclusão e subinclusão). Além disso, ela utiliza apenas a questão abstrata - do que, em tese, dever orientar as decisões legais. Não se apresentam casos concretos, como fazemos na presente.

A relevância dessa outra perspectiva está na constatação da existência de um paradoxo abstrato/concreto, que faz com que, embora em tese as respostas sigam uma determinada orientação, essa orientação possa sofrer alteração quando o juiz está diante de uma situação concreta. Nos experimentos realizados com cidadãos, observou-se que eles tendem a responsabilizar moralmente mais em concreto que em abstrato, dando ensejo a teorias cujo objetivo é explicar os fatores que geram tal distorção ${ }^{14}$. Essas teorias foram, pois, referidas no último capítulo, antes de passar ao estudo das respostas obtidas com os questionários.

Como se vê, a análise é predominantemente descritiva, do que os juízes trabalhistas fluminenses decidem quando em confronto com a situação de sobreinclusão e subinclusão. A preocupação - de cunho normativo - referente à melhor postura a ser adotada pelo Judiciário, seja ele Trabalhista ou não, poderá ser melhor debatida se antecedida da compreensão de como funciona um

${ }^{13}$ SADEK, Maria Tereza. Magistrados Brasileiros: caracterização e opiniões. Disponível em <http://www.amb.com.br/portal/docs/pesquisa/PesquisaAMB2005.pdf > acessado em 22.10.2013.

Pode-se citar, ainda, duas pesquisas anteriores que versam sobre a atuação do Judiciário e a tensão legalidade versus justiça: SADEK, Maria Tereza. A crise do judiciário vista pelos juízes: resultados da pesquisa quantitativa. In Uma introdução ao estudo da justiça. M. T. Sadek (org.). Editora Sumaré, 1995. Disponível em <http://pt.scribd.com/doc/57833300/SADEK-Uma-Introducao-Ao-Estudo-Da-Justica>.

Acessado em 03.02.2014. e VIANNA, Luiz Werneck et al. Corpo e alma da magistratura brasileira. Rio de Janeiro: Editora Revan, 1997.

Há uma pesquisa em curso a respeito dos juízes, o Censo do Poder Judiciário, realizada pelo Conselho Nacional de Justiça, mas que não toca diretamente na questão ora analisada, com foco na carreira do magistrado e nas políticas públicas do Judiciário. A respeito, ver $<$ http://www.cnj.jus.br/pesquisas-judiciarias/censo-do-poder-judiciario $>$. Acessado em 05.02.2014.

${ }^{14}$ MANDELBAUM, Eric e RIPLEY, David. Explaining the abstract/concrete paradoxes in moral psychology: the NBAR hypothesis. Disponível em $<$ http://people.fas.harvard.edu/ mandelbaum/NBAR\%20published\%20Authors\%20copy.pdf >. Acessado em 28.02.2013 
determinado arranjo institucional, quais os principais problemas a serem resolvidos, suas causas e as dificuldades enfrentadas. A opção por ignorar os dados empíricos leva teorias normativas a correrem o risco de se revelar inaplicáveis na prática, porque podem não atacar as causas diretas dos elementos que funcionam mal. Além disso, a posse de indícios a respeito de como decidem os juízes pode evidenciar a (im)procedência de muitas das críticas feitas ao Judiciário, permitindo apontar caminhos de melhora. Sem a compreensão desse funcionamento, fica mais difícil pensar em arranjos institucionais e propostas normativas adequadas a uma maior eficiência da prestação jurisdicional.

A discussão é instigante, já que existem bons argumentos para se perseguir um ou outro ideal. Defende-se a observância das regras, dentre outros motivos, porque espelham a decisão emanada o órgão representativo da população, e invoca-se a persecução do resultado justo porque, por exemplo, todas as regras possuem uma finalidade subjacente cuja implementação foi justamente o objetivo da aprovação da norma jurídica. 


\section{2}

\section{O Estado de Direito}

A pesquisa empírica realizada com cidadãos $^{15}$ - na qual se inspirou o questionário submetido aos juízes trabalhistas fluminenses - concluiu que, em geral, adota-se uma concepção substantiva de Estado de Direito, que resulta na preferência por decisões judiciais que se atêm à justiça do resultado, não prioritariamente à regra jurídica. Por isso, no presente capítulo, busca-se investigar as concepções de Estado de Direito, concepções estas que legitimam um ou outro tipo de solução dos casos submetidos ao Judiciário.

Atualmente $^{16}$, costuma-se mencionar a existência de um Estado de Direito ${ }^{17}$ para informar que um determinado governo é legítimo; que o exercício do poder estatal, inclusive o jurisdicional, se considera adequado do ponto de vista dos cidadãos a ele submetidos. Por isso, objetiva-se nesta seção investigar esse fator legitimante do poder público para, no próximo capítulo, relacionar as formulações conceituais aos modelos formalista e particularista de decisão judicial.

A relevância desse estudo está no fato de que, em meio às incertezas contemporâneas, entende-se que há um ponto de consenso: que o Estado de Direito é um importante fator legitimante da atuação estatal ${ }^{18}$. Previsto na Declaração de Valores Democráticos dos sete países mais desenvolvidos, é senso comum $^{19}$ que a característica que define a tradição política ocidental é a liberdade sob esse tipo de Estado. As razões utilizadas para defendê-lo são distintas nas diferentes sociedades, às vezes embasadas na liberdade, às vezes na preservação da ordem e, outras vezes, na ideia de desenvolvimento econômico, mas sempre

\footnotetext{
${ }^{15}$ SCHWEITZER, N. J.; SYLVESTER, Douglas J. e SAKS, Michael J. Rule violations and the rule of law: a factorial survey of public attitudes. Disponível em $<$ http://papers.ssrn.com/sol3/papers.cfm?abstract_id=951005 $>$. Acessado em 28.02.2013. SCHWEITZER, N. J.; SAKS, Michael J. e LOVIS-MCMAHON, David. Is the rule of law a law of rules? Judgments of rule of law violations. Disponível em $<$ http://papers.ssrn.com/sol3/papers.cfm?abstract_id=1439055>. Acessado em 28.02.2013.

${ }^{16}$ Quando fazemos referência ao tempo atual ou contemporâneo, estamos nos referindo ao final do século XX, início do XXI.

${ }^{17}$ TAMANAHA, Brian Z. On the rule of law: history, politics theory. Nova Iorque: Cambridge University Press, 2004.

${ }^{18}$ Além de Tamanha, também há referência ao Estado de Direito como um fator legitimante dos governos em SCHWEITZER, N. J.; SAKS, Michael J. e LOVIS-MCMAHON, David. Is the rule of law a law of rules? Judgments of rule of law violations. Disponível em $<$ http://papers.ssrn.com/sol3/papers.cfm?abstract id=1439055>. Acessado em 28.02.2013.

${ }^{19}$ Sobre senso comum e senso comum teórico, ver WARAT, L.A. e RUSSO, A. E. Interpretación de Ia Ley. Buenos Aires: Abeledo-Perrot, 1987.
} 
com a característica de essencialidade. Segundo Tamanaha, não se tem lembrança de uma outra concepção política que tenha assumido tal caráter consensual na humanidade ${ }^{20}$.

Como todos os ideais, porém, afirma-se que existem alguns contextos sócioculturais em que o Estado de Direito não funciona e tem que ceder lugar a outros valores sociais mais importantes ${ }^{21}$. Também supõe-se que algumas escolhas devem ser feitas a respeito de como será formulado e implementado, escolhas essas que levem em consideração o contexto e as preferências que prevalecem.

Apesar de sua ascensão a um ideal global, o conceito de Estado de Direito é bastante controverso e é essa controvérsia que gera as disparidades na defesa de uma ou outra prática decisória no Judiciário. Significados conflitantes têm sido utilizados. Isso porque envolve a divergência a respeito da amplitude do Direito que regra esse Estado: ele inclui também ideais de justiça e equidade, ou diz respeito apenas às leis que emanam da autoridade competente? A primeira visão, mais ampla, é considerada substantiva, já que envolve questões éticas e morais. A segunda, mais estrita, diz respeito a uma concepção formal ${ }^{22}$. Por isso, serão analisadas as principais formulações de um e de outro tipo, para depois relacionálas às decisões de autoridade, principalmente àquelas emanadas do Judiciário.

Note-se que a ideia de limitação aos poderes do governante é um dos pontos centrais do conceito, dada a própria denominação do Estado - ele também, por meio de seus governantes, submetido ao Direito. Essa limitação de poder, em grande parte das democracias ocidentais, é exercida por meio do sistema de freios e contrapesos inerente à divisão das funções legislativa, executiva e judiciária em órgãos estatais distintos, sendo o Judiciário um importante ator do sistema ${ }^{23}$. O

\footnotetext{
${ }^{20}$ TAMANAHA, op. cit. p. 04. A respeito do Estado de Direito relacionado à ideia de desenvolvimento econômico, ver RIGOBON, Roberto e RODRIK, Dani. Rule of law, democracy, openness, and income. Estimating the interrelationships. In Economics of Transition, 2005, pp. 533-564. Disponível em <http://www.nber.org/papers/w10750.pdf> . Acessado em 12.01.2014.

${ }^{21}$ TAMANAHA, op. cit. p. 05 .

${ }^{22}$ SCHWEITZER, N. J.; SAKS, Michael J. e LOVIS-MCMAHON, David. Is the rule of law a law of rules? Judgments of rule of law violations. Disponível em $<$ http://papers.ssrn.com/sol3/papers.cfm?abstract_id=1439055 $>$. Acessado em 28.02.2013, p. 02 .

${ }^{23}$ Jeffrey Brand-Ballard afirma que perguntar-se sobre a atuação do juiz, como por exemplo, se o juiz atuou imoralmente ou moralmente, se a decisão foi a que deveria ter dado, o quanto a decisão, se o foi, foi moralmente errada, perguntar-se sobre essas questões, dizia, pode nos ensinar sobre nossa concepção do Estado de Direito. Em Limits of legality: the ethics of lawless judging. Nova Iorque: Oxford University Press, 2010, pp. 3-4.
} 
estudo envolve, desse modo, a investigação dos limites impostos à decisão judicial segundo uma ou outra corrente conceitual.

A análise parte do conceito mais restrito para o mais amplo, ou seja, do que elege menos requisitos para o que incorpora mais requisitos. Cada formulação conceitual subsequente abriga os elementos da anterior, a eles aduzindo outros, numa cumulação progressiva ${ }^{24}$. As concepções formais, de maneira geral, estão relacionadas à forma como a lei foi promulgada, exigindo que o tenha sido pela autoridade competente, que possua clareza suficiente para guiar as condutas e que seu objetivo seja influenciar comportamentos futuros (que seja prospectiva). Focase nas fontes apropriadas e na forma legal. Já as concepções substantivas são aquelas que, além desses fatores, incluem também direitos subjetivos que derivam do ou que embasam o Estado de Direito. Segundo essas formulações, direito "bom” é aquele que abrange esses direitos subjetivos e o "ruim” é o que não os incorpora. Inclui-se, no conceito de Estado de Direito, requisitos de conteúdo ${ }^{25}$. Embora a distinção entre concepções formais e substantivas seja didática, não se deve tomá-la por estrita: tanto as versões formais possuem implicações substantivas quanto as substantivas incorporam requisitos formais, como se verá adiante.

\section{1 \\ Concepções Formais do Estado de Direito}

Tamanaha apresenta três principais concepções formais de Estado de Direito $^{26}$. A formulação que menos requisitos elege para a configuração do Estado de Direito é aquela que pode ser denominada Direito pelo Estado. A norma legal é o meio pelo qual o Estado conduz suas relações e seus afazeres. Uma versão extrema afirma que todas as declarações do soberano, porque provêm dele, são

\footnotetext{
${ }^{24} \mathrm{O}$ estudo das teorias a respeito do Estado de Direito versará apenas sobre o conceito da expressão e os principais argumentos a favor de uma ou outra concepção, sem aprofundar o tema além desses dois pontos, já que são essas as informações importantes para a compreensão dos estudos empíricos analisados no último capítulo. Neles, a pessoa na posição de uma autoridade que viola uma regra para garantir um resultado justo, o que é considerado legítimo pela formulação substantiva de Estado de Direito.

${ }^{25}$ Note-se que há uma distinção importante entre forma e conteúdo, porque pode-se ter segurança (derivada da forma) com qualquer conteúdo, mas não se pode ter justiça com qualquer conteúdo. No entanto, a forma não é completamente destituída de conteúdo. Basta ver que a ideia de leis genéricas está atrelada à isonomia e que a irretroatividade/prospectividade das leis está ligada à segurança jurídica.

${ }^{26}$ TAMANAHA, op. cit. pp. 91-101.
} 
consideradas lei.

Entendido dessa forma, porém, o Estado de Direito não tem um significado real, porque se reduz à noção de legislação pelo governo. Todo Estado moderno é considerado Estado de Direito nesse sentido restrito. Aqui a lei existe não para limitar o governante, mas para servir ao seu poder, o que conflita com a própria expressão "Estado de Direito”.

A segunda formulação do Estado de Direito no sentido formal diz respeito ao que podemos denominar legalidade formal. A ideia é de que o Estado de Direito deve ser capaz de guiar os comportamentos subjetivos. Para tanto, a lei deve ser prospectiva, genérica, clara, pública e relativamente estável. Ela é aplicável igualmente a todos. Além desses elementos, Joseph Raz ressaltou a importância de mecanismos necessários para implementar essas condições da lei: um judiciário independente, audiências públicas, proibição da criação de tribunais de exceção, revisão dos atos legislativos e administrativos e limitações no poder de polícia de modo a garantir a conformidade com o Estado de Direito ${ }^{27}$.

Os adeptos da legalidade formal entram em conflito em dois pontos, quais sejam, como entender a isonomia e se o Estado de Direito representa, ele mesmo, um bem do ponto de vista moral. Hayek defende que a isonomia proíbe discriminações arbitrárias ${ }^{28}$. O problema, segundo Tamanaha, é que essa restrição tem por base um critério substantivo para determinar o que é ou não é arbitrário. Outro problema apontado por este autor diz respeito ao fato de que há uma série de discriminações legais atualmente que poderiam ter sido formuladas de outra forma, ou seja, a vagueza inerente ao termo não permite entender de plano o que é ou não arbitrário. Veja-se, por exemplo, o imposto de renda progressivo, que aumenta de acordo com o aumento da renda da pessoa. Para aferir a existência de discriminação arbitrária é necessário, nesse caso, aduzir argumentos de substância. Por isso, a maior parte dos defensores da legalidade formal entendem a isonomia num outro sentido (também usado por Hayek) ${ }^{29}$ : a lei se aplica de modo igual a todos de acordo com o que está previsto na lei (seja qual for o conteúdo desta), sem distinção entre ricos e pobres, status, etnia, religião ou

\footnotetext{
${ }^{27} \mathrm{RAZ}$, Joseph. The rule of law and its virtue. In The authority of law. Oxford: Clarendon Press, 1979.

${ }^{28}$ HAYEK, Friedrich August. Law, legislation and liberty. A new statement of the liberal principles of justice and political economy. Londres: Routledge, 1998. Volume 3. pp. 98-104.

${ }^{29}$ TAMANAHA, op. cit. p. 94.
} 
qualquer outra característica individual.

Ora, se a todos deve ser aplicada a lei de modo igual de acordo com o que a lei prevê, então temos que pode haver discriminação de etnia ou religião, por exemplo, segundo essa corrente. Porque o balizador para saber o que é ou não tratamento discriminatório é a própria lei e se a lei dá o balizador então na sua edição não há limites para o estabelecimento de critérios. Caímos num círculo vicioso, em que lei deve respeitar a isonomia, mas ela própria estabelece o que é isonômico... Na verdade, dizer isso e não dizer nada daria no mesmo.

Quanto ao segundo ponto de divergência, referente à questão de se o Estado de Direito representa, ele mesmo, um bem do ponto de vista moral, Fuller defende positivamente, já que promove a autonomia individual. Além disso, continua, o Estado de Direito possui uma “afinidade” com o bom, já que os sistemas legais com essas características formais tem uma propensão maior à justiça ${ }^{30}$. Raz, porém, apresenta um argumento contra essa concepção, fazendo uma analogia com a faca ${ }^{31}$, deixando claro que a moralidade da lei é uma função de como ela é adotada. Segundo o autor, se um determinado regime merece ou não ser considerado meritório não é uma questão de se ele adota ou não o Estado de Direito (embora essa possa ser uma parte da avaliação), mas sim do conteúdo moral das suas leis, de como elas são aplicadas e de suas consequências. A ideia de obedecer a lei, seja qual ela for, pode ter consequências terríveis.

Tamanaha afirma que uma concepção mais sensível aceita alguns argumentos de ambas as partes. A legalidade formal promove a dignidade dos cidadãos na medida em que permite que haja previsibilidade suficiente para planejar suas vidas, sem dúvida um ganho do ponto de vista moral. De certa forma, portanto, o Estado de Direito sob esse ponto de vista é um bem. Mas isso não é suficiente, segundo o autor. Tão importante quanto essa constatação é considerar as implicações morais do conteúdo da lei e de seus efeitos, porque tal é necessário para definir o que torna, de fato, a obediência à lei uma obrigação moral. $^{32}$ A adoção do ponto de vista exclusivamente com base na legalidade formal vai de encontro à longa tradição do Estado de Direito, que é restringir a

\footnotetext{
${ }^{30}$ FULLER, Lon L. The morality of law. $2^{\mathrm{a}}$ edição revista. New Haven: Yale University Press, 1969.

${ }^{31}$ Uma boa faca, segundo esse autor, é, dentre outras, uma faca afiada. Mas a faca pode ser usada para matar ou para cortar vegetais. Do mesmo modo, da conformidade com o Estado de Direito e com a lei não decorre que haja justiça. Op. cit. p. 189.

${ }^{32}$ Op. cit. p. 96.
} 
tirania do soberano.

A terceira e última concepção formal do Estado de Direito agrega, aos elementos já enunciados pelas teorias anteriores, a exigência de um procedimento democrático na edição das leis. Jurgen Habermas é autor da teoria mais sofisticada a respeito dessa terceira vertente. De acordo com essa corrente, a legitimidade de uma lei é extraída da autodeterminação: os cidadãos devem ser capazes de se entender como coautores das leis que são obrigados a obedecer, mesmo que tais leis sejam aprovadas pelos seus representantes ${ }^{33}$. Neste sentido, a autoridade do Direito decorre do consentimento dos governados. Ela é embasada neste processo democrático e, ao mesmo tempo, serve a ele: sem a legalidade formal, a democracia pode ser violada, já que os governantes podem descumprir as leis. Sem a democracia, a legalidade formal perde sua legitimidade.

Segundo Habermas, a perda da fé no Direito Natural e o pluralismo moral existente na atualidade não deixam alternativa senão a de excluir o conteúdo moral do conceito de Estado de Direito e trabalhar apenas com a existência de um procedimento democrático, que assegure a todos os afetados pela lei uma oportunidade igual de participar, além de exigir o consentimento dos possíveis atingidos. Questiona-se que tipo de consentimento é exigido, já que não há democracia direta com consentimento unânime atualmente. Kant argumenta que o consentimento de todos os cidadãos não é o consentimento real, mas sim o que os cidadãos aceitariam se agissem de acordo com a razão ${ }^{34}$. Já Habermas explicitamente exige a unanimidade, mas numa análise final não o faz, pois coloca como requisito dessa unanimidade um arranjo comunicativo que é idealizado. $\mathrm{Na}$ verdade, esses teóricos apresentam um ideal regulatório, estabelecendo uma meta que os sistemas legais deveriam perseguir sem, de fato, esperar que na prática isso seja alcançado dessa forma.

Locke defende que, na realidade, o requisito é de consentimento de cada cidadão de ser governado por meio de um sistema representativo que atua de acordo com a decisão da maioria. O consentimento, portanto, não é dado a cada conteúdo legal aprovado, mas apenas no que se refere ao procedimento. Enquanto uma pessoa ou grupo do lado que perdeu uma determinada questão tiver uma

\footnotetext{
${ }^{33}$ HABERMAS, Jurgen. Between facts and norms: contributions to a discourse theory of law and democracy. Translated by William Rehg. Massachusetts: The MIT Press, 1996, Capítulos 7 e 8.

${ }^{34}$ TAMANAHA, op. cit. p. 100.
} 
chance de prevalecer em outra matéria, o sistema será livre. ${ }^{35}$

\section{2 \\ Concepções Substantivas do Estado de Direito}

Para compreender a decisão judicial e a pesquisa empírica que será apresentada no último capítulo, que busca aferir a concepção de Estado de Direito dos cidadãos, faz-se necessário fixar alguns elementos básicos. A legitimidade do exercício do poder estatal, inclusive jurisdicional, tem sido vista com base na adoção do Estado de Direito, cujo conceito é bastante controverso. As teorias formais principais sobre o tema são denominadas Direito pelo Estado, legalidade formal e democrática. As teorias substantivas, que ora serão analisadas, incorporam elementos das formais e acrescentam outros, sendo que as mais comuns incluem os direitos individuais no conceito de Estado de Direito. Como exemplo, pode-se citar a formulação de Dworkin. ${ }^{36}$ Não se distingue, nesse caso, o Estado de Direito da justiça substantiva. A ordem jurídica ideal incorpora e torna efetivos os valores morais de uma sociedade. Vejamos o que diz o autor:

Um voto da maioria não alcança a legitimidade requerida a menos que, primeiro, todos os cidadãos tenham a independência moral necessária para participar da decisão política como agentes morais livres, e a menos que, segundo, o processo político seja tal que trate todos cidadãos com igual consideração e respeito. Se isto está certo, os pressupostos da democracia incluem alguns direitos - quais deles é uma questão para se debater tendentes a assegurar tais condições. Deve-se incluir a liberdade de consciência e religião assim como a liberdade de expressão política e devese garantir que decisões políticas não estabeleçam preconceito contra qualquer grupo, desdenhando-os ou não os diferenciando na medida em que seja necessário. ${ }^{37}$

Para o autor, tais direitos não estão garantidos pela lei positiva, mas sim formam uma base sobre a qual deve ser construída a legalidade. A origem de tais direitos não estaria na metafísica, mas na própria comunidade. As leis representam o esforço comunitário para capturar os direitos morais, mas não é a fonte exclusiva de tais direitos. Além disso, as leis podem conter lacunas ou produzir interpretações conflitantes. Nesses casos, segundo essa teoria, é dever do juiz

\footnotetext{
${ }^{35}$ Idem.

${ }^{36}$ DWORKIN, Ronald. Constitucionalismo e democracia. Texto traduzido para fins acadêmicos por Emílio Peluso Neder Meyer. [S.l.:s.n.,2013?]. Publicado originalmente no European Journal of Philosophy, no 3:1, p. 2-11, em 1995.

${ }^{37}$ Idem, p. 06.
} 
tomar a decisão que melhor se amolda à base moral formada pelos direitos individuais, consistente com as regras e princípios do ordenamento jurídico, perquirindo o que o legislador deveria ter estabelecido de modo a se respeitar os princípios políticos que embasam o sistema normativo.

As demais formulações substantivas, mais abrangentes, incluem, além da legalidade formal, democracia e direitos individuais, outras dimensões qualitativas que poderiam ser de grosso modo classificadas como direitos sociais (social welfare rights). O exemplo em maior evidência é aquele das conclusões da Comissão Internacional de Juristas do significado do Estado de Direito, obtidas em uma conferência em 1959 a respeito do tema. Ressaltou-se que o conceito de Estado de Direito, de fato, garante e protege os direitos civis e políticos dos indivíduos numa sociedade livre, mas também é preocupado com o estabelecimento, pelo Estado, de condições sociais, econômicas, educacionais e culturais suficientes para que os cidadãos possam realizar seus planos de vida dignamente. Aduziu-se que a liberdade de expressão não tem sentido para pessoas que não sabem ler e escrever; o direito de votar pode ser utilizado como instrumento de tirania, aproveitando-se de um eleitorado sem instrução; liberdade da intervenção governamental pode não significar liberdade para os esfomeados e destituídos de condições mínimas de vida.

Nessa formulação substantiva, o Estado de Direito impõe ao governo uma obrigação positiva de fazer com que a vida seja melhor para o povo, promovendo a dignidade, inclusive com utilização de justiça distributiva. De acordo com Tamanaha, o Estado de Direito alemão do pós-guerra deu um passo nessa direção com o reconhecimento do direito de dignidade ${ }^{38}$.

Embora seja importante fazer referência a tais concepções, a pesquisa empírica analisada no último capítulo versa não sobre direitos sociais, mas sobre direitos individuais. Desse modo, o contraponto de maior interesse para o âmbito do estudo de campo realizado é aquele que se faz entre as correntes formais, por um lado, e as correntes que incorporam ao conceito de Estado de Direito os direitos individuais, por outro.

\footnotetext{
${ }^{38}$ Op. cit. p. 113.
} 


\section{3}

\section{O Estado do Bem-estar Social e o Governo de Juízes e Advogados}

Diante desse cenário de concepções a respeito da legitimidade do poder estatal, inclusive do judicial, que ora agrega elementos apenas de forma, ora de forma e conteúdo, nota-se que duas preocupações principais, ligadas ao campo normativo, permeiam a ideia de Estado de Direito. A primeira delas diz respeito ao argumento de que é incompatível com uma expansão do Estado do Bem-estar Social e com a justiça distributiva. Teóricos muitas vezes vinculam o Estado de Direito ao liberalismo e ao capitalismo irrestrito.

Embora o Brasil nunca tenha chegado a estruturar um Estado de Bem-estar semelhante aos dos países de primeiro mundo ${ }^{39}$, essa discussão não é irrelevante no país, já que a Constituição da República de 1988 consagra diversos direitos sociais e princípios que são utilizados para fundamentar decisões judiciais, mesmo no âmbito da sobreinclusão e subinclusão discutidas no presente trabalho. Desse modo, considerando-se que o país adota o Estado de Direito e, ainda, alguns direitos sociais, então a questão da compatibilidade entre um e outros não pode passar despercebida.

A segunda preocupação é concernente à ideia de que o Estado de Direito pode se tornar o governo dos juízes e advogados. Esse ponto tem estreita relação com a pesquisa empírica descrita no último capítulo, vez que diz respeito aos argumentos que defendem ou criticam uma prática decisória judicial que incorpora elementos morais e de justiça em seu âmbito. Segundo Tamanaha, tal preocupação ainda levanta preocupações adicionais em sociedades cujo corpo de advogados e juízes vem exclusivamente da elite ou de outro subgrupo ${ }^{40}$, porque faz prevalecer a concepção de justiça e de moralidade destes.

Quanto à primeira preocupação, não se constata, qualquer que seja o conceito de Estado de Direito adotado, uma incompatibilidade entre o instituto e o bem-estar social. Com efeito, se se considerar a formulação mínima, de Direito pelo Estado, não há óbice para que o soberano incorpore ao Direito vigente normas que consagrem direitos sociais. O mesmo pode ser dito de todas as concepções formais acima expostas. Caso se considerem as formulações

\footnotetext{
${ }^{39}$ CANCIAN, Renato. Estado do bem-estar social: história e crise do welfare state, 2007. Disponível em <http://educação.uol.com.br/disciplinas/sociologia/estado-do-bem-estar-socialhistoria-e-crise-do-welfare-estate.htm>. Acessado em 24.02.2014. ${ }^{40}$ Op. cit. p. 05.
} 
substantivas, também não existe uma incompatibilidade, mesmo que se adote a primeira formulação, de integração apenas de direitos individuais. Ora, muitos países $^{41}$ incorporaram ao seu ordenamento jurídico tanto direitos civis e políticos como os sociais do bem-estar sem que isso inviabilizasse o respeito às liberdades e garantias individuais. Segundo Tamanaha, muitas das sociedades orientais que desejam implementar o Estado de Direito não têm a intenção de se tornar liberais e muitos países ocidentais que já o implementaram estão compromissados com o Estado do Bem-estar Social ${ }^{42}$.

De modo contrário ao afirmado por Hayek, Tamanaha ressalta que o Estado do Bem-estar Social não necessariamente ameaça o Estado de Direito. Ele cria áreas de governabilidade não adstritas às restrições legais, como por exemplo os programas sociais. Além disso, para funcionar, depende também da existência e observância das leis.

A segunda preocupação, referente ao governo de juízes e advogados, culmina, por vezes, na defesa de uma concepção formal do Estado de Direito, que confere menor poder aos que atuam em juízo. A favor da legalidade formal, diz-se que ela promove a autonomia individual e a dignidade porque permite às pessoas planejar suas atividades com prévio conhecimento de suas potenciais implicações legais. Além disso, a recomendação desse tipo de formulação em geral está calcada na ideia de neutralidade, porque não agrega elementos de conteúdo à lei, somente de forma.

Todavia, se esse modelo permite o planejamento da vida com a prévia ciência das regras sociais, ele também acaba por privilegiar, ao final, a força em detrimento da razão. E aqui a força é utilizada no seu sentido político, porque é provável que os que possuem maior influência no ente responsável pela edição de leis editarão as regras com o conteúdo que desejam. Se, diferentemente, incluímos a discussão dos requisitos de conteúdo de um Estado de Direito no debate, existe uma chance maior de vencer não a força política proeminente, mas o melhor argumento. Sendo assim, discutir o conteúdo mínimo do Direito para que o Estado seja legítimo pode ter um caráter mais isonômico do que não discuti-lo e deixá-lo para a decisão das forças políticas atuantes na sociedade. A legalidade formal

\footnotetext{
${ }^{41}$ Como exemplo, pode-se citar os países da Europa Ocidental na segunda metade do século XX. A esse respeito, ver CANCIAN, Renato. Op. cit.

${ }^{42}$ Op. cit. p. 05.
} 
permite, por exemplo, que o governo faça o que quiser, porque basta, para realizar algo proibido, modificar a lei antes de fazê-lo. Desse modo, essa formulação tem mais pontos em comum com a do "Direito pelo Estado" que com a tradição do Estado de Direito ${ }^{43}$.

Além disso, as características de generalidade, clareza, certeza e prospectividade são inerentes a qualquer regra legal, não ao Estado de Direito. A generalidade, por exemplo, diferencia a lei de uma ordem. Leis incertas ou não claras têm eficácia limitada no que tange a guiar comportamentos. Uma norma legal retroativa é um oximoro, porque não pode ser seguida. Ao final, não há um traço distintivo do Estado de Direito como um ideal separado, porque os argumentos de tal concepção formal são os mesmos considerados para caracterização de qualquer lei.

A legalidade formal (ou o formalismo legal) nada diz sobre a pergunta essencial concernente às áreas ou atividades que deveriam ser regradas por leis, sobre capitalismo, liberalismo ou Estado de bem-estar social. Essas são questões de escolhas sociais. Como dito, na verdade legitima-se a concepção política mais forte, com maior poder na sociedade. Daí se pode extrair, mesmo que indiretamente, uma ligação com o capitalismo, modo de organização com grande força política na atualidade. Mas essa não é uma ligação necessária e sim estrutural.

Mesmo quando se pensa na concepção formal que agrega a democracia, nota-se que pode haver leis ruins do ponto de vista moral, embora de fato seja o melhor meio de mudar líderes políticos. Tamanaha argumenta que a formulação restrita, seja ela qualquer uma das três apresentadas, é compatível com o nazismo. Diz que uma solução para esse problema é simplesmente atribuir um papel mais limitado ao Estado de Direito. Uma visão mais restrita poderia ser vista como condição necessária, mas não suficiente, de um sistema político desejável. Os defensores da visão mais estreita não advogam o nazismo ou o estalinismo, por exemplo. De acordo com o mencionado autor, o conceito poderia funcionar melhor se não lhe incutissem elementos demais. No entanto, a ideia de funcionalidade está atrelada à instrumentalidade. Desse modo, indaga-se: o

\footnotetext{
${ }^{43}$ Para um conhecimento a respeito do surgimento e configuração das tradições, ver HOBSBAWN, E. e TERENCE, R. A invenção das tradições. Tradução de Celina Cardim Cavalcante. $6^{\mathrm{a}}$ ed. Rio de Janeiro: Paz e Terra, 1997.
} 
conceito poderia funcionar melhor para atingir que finalidade? Veremos adiante que essa não é uma pergunta irrelevante e que, na verdade, a finalidade a que se propõe o conceito de Estado de Direito - a de legitimação de governos - pede mais que elementos apenas formais.

Patrick Brennan argumenta que a visão procedimental acaba por ignorar ou não compreender corretamente o elemento subjetivo. Segundo ele, a mente humana, seus desejos e a conduta resultante pode e deve ser incluída no Estado de Direito $^{44}$. De outro lado, o filósofo moral Alastair MacIntyre chamou a atenção para o fato de que a discordância para o que sejam os direitos morais e para sua extensão é evidente atualmente ${ }^{45}$. Pode-se citar como exemplo as discussões a respeito do aborto, ações afirmativas em questões de emprego e educação, direitos dos homossexuais, a pena de morte, o discurso de ódio, o acesso à pornografia, dentre outros. A discordância vai além dos direitos propriamente ditos, englobando também os remédios adequados para, por exemplo, promover as ações afirmativas ou coibir o aborto. E tudo isso, segundo o autor, não diz respeito a questões periféricas, mas ao cerne dos princípios políticos que regem uma sociedade.

Tamanaha afirma que, quando uma comunidade está dividida em suas formulações morais, não se pode confiar na afirmação de que o ordenamento jurídico, os princípios políticos ou a moralidade comunitária terão coerência ou consistência interna. Defende que talvez nem mesmo haja uma visão moral única ou majoritária. Diz que não se pode nem mesmo assumir que o Legislativo está sempre motivado a criar leis que espelham fielmente a moral comunitária. A influência de interesses particulares em assegurar leis que lhes sejam favoráveis é notória.

O autor aduz que essas objeções acabam por atingir todas as versões substantivas do Estado de Direito que incorporam os direitos individuais, não apenas a de Dworkin. Os ideais de equidade, liberdade, privacidade e direito de propriedade, por exemplo, são objeto de discordância no seu significado e extensão. Segundo o mencionado autor, o grande problema da teorização de Dworkin é a promessa de remover as disputas da arena política, colocando-as

\footnotetext{
${ }^{44}$ COONS, John E. e BRENNAN, Patrick. By nature equal: the anatomy of a western insight. New Jersey: Pinceton University Press, 1999.

${ }^{45}$ MACINTYRE, Alastair. After virtue. Notre Dame: Notre Dame University Press, 1984.
} 
apenas nas mãos dos juízes. Sendo assim, conclui, a concepção substantiva que incorpora ao Estado de Direito a exigência de contemplação dos direitos individuais possui inevitáveis implicações antidemocráticas.

\section{4}

\section{Implicações Antidemocráticas da Concepção Substantiva de Estado de Direito}

A preocupação de que o Estado se torne o governo de juízes e advogados, dada a amplitude de poder que se confere a essas categorias com a formulação substantiva de Estado de Direito, conduz muitas vezes à defesa de uma concepção formal, que não agrega elementos de conteúdo ao conceito. Mas, como visto, a concepção formal acaba por privilegiar a força política e, diante de discordâncias morais, fazer prevalecer a visão daqueles que possuem o poder, sendo compatível até mesmo com o nazismo. Por outro lado, conceituar o Estado de Direito como pretende a corrente da legalidade formal não traz nenhuma vantagem do ponto de vista teórico, visto que o conceito se confunde com o de qualquer lei, que também deve ser genérica, clara, certa e prospectiva.

Mesmo com esses argumentos a favor de uma concepção substantiva do Estado de Direito, que inclusive se supõe adotada pelos cidadãos, como demonstra a pesquisa empírica analisada no último capítulo e já mencionada, é preciso enfrentar algumas ponderações no sentido de que a formulação substancial traz implicações antidemocráticas. Há duas facetas do problema segundo Tamanaha: os limites impostos à democracia e o poder conferido aos juízes. No que se refere à primeira faceta, uma resposta seria aquela concernente à necessidade da proteção das minorias frente à decisão da maioria. Tamanaha inicia dizendo que os primeiros liberais tinham uma atitude ambivalente frente à democracia. Embora a tenham defendido, observaram que a democracia não poderia ser absoluta. Isso porque a liberdade pode ser vista como liberdade política, de cada um poder governar a si próprio, mas também pode ser vista como liberdade ao direito à propriedade e liberdade da opressão majoritária. Assim, para o liberalismo, o Estado de Direito estaria mais conectado à liberdade individual que à democracia, prevalecendo o sentimento de medo da massa majoritária pobre, que poderia querer redistribuir as riquezas. Os direitos individuais, portanto, seriam mais importantes que a democracia, quando em conflito. 
Importante notar, como ressaltou Jeffrey Brand-Ballard ${ }^{46}$, que a posição política a favor ou contra a deferência do Judiciário (e, pois, dos direitos individuais) ao legislado democraticamente varia com o tempo, tendo havido épocas em que os Republicanos defenderam uma atitude mais pró-ativa dos juízes e épocas em que foram contra, podendo-se dizer o mesmo dos Democratas. Em muito essa posição dependia da composição da Suprema Corte. Dessa forma, pode-se inferir que a postura política frente o conflito entre os direitos individuais e o legislado democraticamente varia no tempo, muitas vezes de acordo com a conveniência.

Uma outra resposta para a objeção antidemocrática diz respeito ao argumento de que os direitos individuais são requisito de manutenção da própria democracia. Só pessoas livres podem exercer a real democracia. Assim, segundo essa visão, os direitos de propriedade, de liberdade de associação e de liberdade de expressão são pré-requisitos para a configuração do autogoverno e da autodeterminação individual que a democracia pressupõe. Logo, a democracia seria restringida pelos direitos individuais para o bem da própria democracia.

Segundo Tamanaha, esse argumento contradiz a tradição liberal de situar a democracia em nível inferior ao dos direitos individuais. Ele aduz que nem todos os direitos individuais são justificáveis porque benéficos à democracia, retirando dos direitos o valor intrínseco que recebem nas sociedades liberais.

A segunda faceta antidemocrática diz respeito ao poder conferido aos juízes. Observe-se que alguém deve dizer, no caso concreto, o significado e a extensão do direito individual e quais são os limites que este direito impõe ao Legislativo. $\mathrm{Na}$ maioria das democracias liberais ocidentais, esse poder é conferido aos juízes, no chamado judicial review of legislation ${ }^{47}$. O argumento é de que quando os juízes não são eleitos, isso confere a um grupo de indivíduos não atrelado à democracia o poder de "vetar" leis criadas democraticamente.

Responde-se afirmando que, se este poder fosse conferido a um ente composto por pessoas eleitas, o objetivo principal de proteger minorias poderia ser frustrado. Tamanaha afirma que se houvesse um consenso a respeito do sentido e alcance dos direitos individuais, não haveria qualquer problema com esse tipo de configuração institucional. Entretanto, continua, dada a diversidade

\footnotetext{
${ }^{46}$ Op. cit, pp. 17-18.

${ }^{47} \mathrm{O}$ que pode ser traduzido por controle de constitucionalidade das leis e atos normativos.
} 
de concepções a respeito da moralidade, se cada juiz consultar sua própria visão para estabelecer o conteúdo dos direitos, o sistema não seria mais o do Estado de Direito, mas sim o Estado dos Juízes. Mas a diversidade de entendimentos não pode ser justificativa para permitir que uma minoria seja prejudicada. Admitindose que tal divergência moral exista, esse é mais um dado que reforça a necessidade de se criar mecanismos para que as minorias tenham também chance de ver prevalecer seu ponto de vista, em especial quando o acesso ao cargo de juiz é realizado de forma predominantemente objetiva, por meio de concurso público, por exemplo. A se depender única e exclusivamente de órgãos eleitos, a visão da maioria a respeito da moralidade dominará sempre.

Tamanaha ressalta que os defensores da concepção substantiva percorrem três caminhos principais para preservar a integridade da lei da ameaça antidemocrática e do subjetivismo. O primeiro caminho diz respeito à insistência no fato de que os juízes interpretam de acordo com o significado evidente dos direitos, em fidelidade à intenção dos cidadãos e dos representantes que os estabeleceram. A crítica apontada pelo autor é concernente à inexistência de um significado claro ou evidente dos direitos individuais e que às vezes tal significado aponta para um sentido oposto ao da intenção quando da criação da lei. Além disso, há dificuldade em se aferir a intenção do legislador e de seus representados; tal intenção poderia não contemplar um problema que só surgiu depois; ou poderia haver uma variedade de intenções quando da aprovação da regra ou princípio jurídico.

Não parece, porém, que haja uma tal indefinição e ausência de consenso que seja capaz de transformar o poder conferido aos juízes em poder de criar todo o Direito. Como se verá no próximo capítulo, não se pode negar que a ordem jurídica possui uma "textura aberta” em que o juiz acaba por fazer escolhas. Mas esta "textura aberta” - e a indefinição dos direitos individuais - não é tal que transforme o Direito apenas no que é dito pelos juízes. ${ }^{48}$

O segundo caminho é o trilhado por Dworkin, que nega que os juízes consultem sua própria visão de moralidade, recorrendo, ao revés, à comunidade para achar os princípios prevalentes. Como a fonte dos princípios é a própria comunidade, então a decisão judicial tem um viés democrático. Nesse sentido, os

\footnotetext{
${ }^{48}$ Ver capítulo 3, pp. 51-54.
} 
juízes, mesmo quando invalidam a lei sob o argumento de violação a direitos individuais, atuam de modo a dar suporte à democracia. A crítica a tal visão diz respeito à mesma ideia de existência de princípios conflitantes em uma comunidade plural e ao fato de que será sempre a visão do juiz a respeito dos princípios da comunidade, o que é muito difícil de distinguir dos princípios do próprio juiz.

Tamanaha afirma, ainda, que é estranho caracterizar os juízes como atores da democracia quando a crença no desenho institucional que dá base ao Estado de Direito é justamente de que os juízes formam um corpo a parte das forças políticas, independente, de modo que suas decisões se pautem apenas nas leis. Na verdade, os juízes são criticados se vistos agindo politicamente. A resposta de Dworkin é a de que o que não se pode admitir são decisões que adentram as políticas públicas, não decisões embasadas em princípios, sendo essas últimas consistentes com a democracia ${ }^{49}$. Embora haja dificuldade em se distinguir uma questão da outra - a principiológica da política - não se pode negar que a atuação judicial é a forma mais eficiente que atores sociais não dotados de força pública suficiente para eleger representantes no Legislativo e Executivo possuem para implementar sua interpretação dos princípios.

O terceiro caminho argumentativo traçado para contestar a objeção antidemocrática é aquele que diz respeito ao reconhecimento de que nos casos em que o significado ou a extensão do direito individual não é evidente, o juiz deve de boa-fé aplicar o que considera a decisão correta, fundamentando-a com argumentos que demonstram que é a melhor interpretação dos direitos naquela situação considerando-se todos os dados disponíveis (all things considered). Isso pode ser um desvio da ideia de democracia, mas um desvio inevitável, dadas as características do sistema jurídico. Presumivelmente, a visão do juiz será formada pela sociedade que ele integra e pela cultura legal de sua comunidade. Não será, pois, uma decisão arbitrária ou isolada.

Segundo Tamanaha, comparando-se os muitos casos julgados, a frequência

\footnotetext{
${ }^{49}$ Dworkin denomina “'política' aquele tipo de padrão que estabelece um objetivo a ser alcançado, em geral uma melhoria em algum aspecto econômico, político ou social da comunidade (ainda que certos objetivos sejam negativos pelo fato de estipularem que algum estado atual deve ser protegido contra mudanças adversas)." e denomina "'princípio' um padrão que deve ser observado, não porque vá promover ou assegurar uma situação econômica, política ou social considerada desejável, mas porque é uma exigência de justiça ou equidade ou alguma outra dimensão da moralidade.” In Levando os direitos a sério. Tradução Nelson Boeira. São Paulo: Martins Fontes, 2002, p. 36.
} 
de aparecimento de um caso de interpretação de direitos e invalidação da legislação pelo Judiciário é muito pequena. Entretanto, ressalta que, quando um desses casos aparece, as consequências são bastante relevantes, porque dizem respeito a matérias sobre as quais a sociedade é dividida. Informa que a autodeterminação e autorregulação são violadas se as mais importantes decisões são tomadas por outra pessoa.

De fato, a deferência do Judiciário ao legislado deve ser a regra, de modo a se respeitar as decisões políticas tomadas pelos cidadãos por meio de seus representantes. O problema aparece quando as normas entram em conflito, seja ele um conflito de princípios, entre princípios e regras ou entre regras, porque o Judiciário não pode se furtar a dar uma resposta. Todos esses tipos de enunciados normativos estão igualmente previstos no ordenamento jurídico. Além disso, não se pode relegar aos direitos individuais, políticos e sociais previstos na Constituição de determinado país um caráter apenas programático, tendo, ao revés, efeitos no sistema jurídico.

O mesmo autor afirma que, talvez, o maior perigo seja para o próprio Judiciário. Acreditar que a política é um aspecto inevitável da interpretação dos direitos e observar o tamanho do poder que isso confere aos juízes pode levar a uma seleção de candidatos com determinada orientação ideológica. Continua dizendo que sinais disso estão aparecendo no que se refere ao Judiciário federal dos Estados Unidos, o que pode politizar o Judiciário, comprometendo sua credibilidade como um órgão distinto das forças políticas atuantes na sociedade.

Sucede que a seleção de juízes com base numa determinada ideologia pode ocorrer não só quando há indicação política, mas também nos concursos públicos, embora seja mais difícil de ser constatada neste último caso. Reconhecer que o juiz também possui uma certa atuação política e que isso pode ser levado em consideração no momento da seleção não compromete sua credibilidade. Ao revés: dá transparência ao processo, deixando claro que tipo de orientação está sendo utilizada para fins de preenchimento dos cargos. A escolha, ao contrário, por negar completamente os fatos políticos que envolvem a nomeação de juízes leva a opções menos claras e menos transparentes do ponto de vista ideológico, o que não é saudável numa democracia.

Vistas as duas preocupações que cercam a ideia de Estado de Direito, concluímos que tal ideia é compatível com o Estado do Bem-estar Social e que, 
no que se refere ao "governo de advogados e juízes", as facetas antidemocrática e de entrega de poderes aos juízes pode ser respondida com base na ideia de que o Judiciário pode ser uma forma de expressão do ponto de vista das minorias e de sua proteção. Isso não significa defender que os magistrados possam legitimamente aplicar qualquer entendimento que tenham a respeito de determinado assunto em detrimento das fontes normativas. Quer dizer algo menos pretensioso: que não se pode afirmar que qualquer concepção substantiva de Estado de Direito é ruim do ponto de vista moral porque confere muito poder aos juízes ou porque é antidemocrática. Há graus de poder conferido ao Judiciário segundo uma ou outra concepção substantiva adotada.

Além disso, como será visto no capítulo três, as características do sistema jurídico já fazem com que os juízes possuam algumas possibilidades de escolha, escolhas essas que são ainda mais relevantes quando o Direito de um determinado país incorpora conceitos com baixo grau de determinação, como os direitos individuais, políticos e sociais. Não se discorda, no presente estudo, da circunstância de que a observância das leis aprovadas democraticamente deve ser a regra; que só excepcionalmente os juízes poderiam decidir de forma divergente do que estabelecem as fontes formais. Porém, essa afirmativa não conduz necessariamente à conclusão de que os juízes de qualquer país devam se limitar a observar os requisitos formais; que nunca poderiam legitimamente deixar de aplicar o Direito que obedecesse aos requisitos de forma. Como se verá, o Judiciário tem o direito de não aplicar uma lei que estabeleça, por exemplo, o trabalho escravo, porque isso contraria os requisitos mínimos de um Estado legítimo.

\section{5}

\section{Manifestações do Estado de Direito no Mundo e Uso da Expressão}

As concepções formais e substantivas de Estado de Direito conduzem a diferentes compreensões a respeito de que tipo de decisão judicial é considerada legítima, se assim o é quando observa a regra jurídica mesmo em caso de não ser condizente com os valores morais do magistrado ou quando a descumpre para garantir a aplicação de um resultado justo, que consagre um direito individual ou social. Foram vistos, nos tópicos anteriores, argumentos que defendem um ou outro tipo de formulação de Estado de Direito e que tocam especialmente na 
questão do poder conferido aos juízes e das implicações antidemocráticas desse poder. Passa-se, nesse momento, à análise de algumas manifestações e forma de compreender o Estado de Direito no mundo, especialmente fazendo referência a alguns traços de sua configuração no Brasil.

Fletcher ${ }^{50}$, ao identificar as versões restrita e ampla do Estado de Direito, sugeriu que a visão anglo-americana e a européia diferem, já que esta última está mais para a formulação substantiva e a primeira mais para a restrita, embora haja muitos autores estadunidenses que explorem o argumento substantivo, como Dworkin, por exemplo. A visão germânica contemporânea do Estado de Direito deixa clara a tensão entre democracia e direitos individuais. Tal visão passou por diferentes fases, iniciando com a influência do liberalismo de Kant e da ênfase nos direitos formais que asseguravam liberdade igual a todos.

A partir do meio do século XIX e até a metade do século XX, o Estado de Direito foi concebido mais como Direito pelo Estado (formulação formal que menos requisitos elege para a configuração do Estado de Direito). Nesse período não existia (ou era pouco relevante) o controle de constitucionalidade das leis pelo Judiciário. Vigorava a centralidade da lei e a supremacia do Parlamento. ${ }^{51}$

Após a Segunda Guerra Mundial, a Constituição Germânica foi alterada para incluir elementos substantivos, em especial o da dignidade humana, sendo explícita ao afirmar que existem direitos universais e extralegais, que independem de seu reconhecimento pelo Estado. Situou-se, pois, a proteção dos direitos individuais na noção de Estado de Direito, sendo tal concepção inalterável, segundo a Constituição, pela ação do Legislativo.

Não só foram incorporados elementos substantivos, como também inciou-se na Europa continental o reconhecimento de que as normas constitucionais são diretamente aplicáveis, não dependendo necessariamente de desenvolvimento pelo legislador ou pelo administrador, no que se chamou de Estado Constitucional de Direito $^{52}$ em substituição ao anterior Estado Legislativo de Direito. Tamanaha

\footnotetext{
${ }^{50}$ FLETCHER, George. Basic Concepts of Legal Thought, 1996. Apud ROSE, Jonathan. The rule of law in the western world: an overview. Disponível em $<$ http://papers.ssrn.com/sol3/papers.cfm?abstract_id=1426343 > acessado em 06.05.2013, p. 3.

${ }^{51}$ BARROSO, Luis Roberto. Constituição, democracia e supremacia Judicial: Direito e política no Brasil contemporâneo. In Revista da Faculdade de Direito - UERJ, v. 2, n. 21, jan./jun. 2012, $\quad$ p. $04 . \quad$ Disponível em $<$ http://www.oab.org.br/editora/revista/revista_11/artigos/constituicaodemocraciaesupremaciaj udicial.pdf $>$. Acessado em 05.02.2014.

${ }^{52}$ Idem, p. 03.
} 
pondera que essa escolha acabou por ressaltar o problema de como os juízes lidam com a questão da indeterminação dos direitos, especialmente o da dignidade da pessoa humana. Além disso, muitas disputas políticas foram transformadas em questões constitucionais, na chamada judicialização da política.

Não só na Alemanha, mas em várias partes do mundo, como na América Latina (inclusive Brasil) e na Europa Oriental pós-comunista nota-se uma crescente ação do Judiciário e de seu poder na revisão das leis com base nos direitos individuais. A jurisdição constitucional no Brasil, entendida como a interpretação e aplicação da Constituição por órgãos judiciais ${ }^{53}$, é exercida por todos os juízes e tribunais, situando-se o Supremo Tribunal Federal no topo do sistema. Ela contempla tanto a aplicação direta da Constituição - caracterizada como analítica e abrangente ${ }^{54}$ - às situações nela estabelecidas, como também o controle de constitucionalidade das leis e atos normativos.

O controle de constitucionalidade brasileiro combina a matriz americana de controle difuso, exercido por todo juiz e tribunal, com o controle concentrado de matriz européia, que estabelece ações diretas ajuizáveis perante a corte constitucional. Desse modo, muitas são as questões levadas ao Judiciário, especialmente considerando-se os diversos legitimados a propor as ações diretas.

Tamanaha afirma que quando o Judiciário se sobrepõe às instituições democráticas, o fato fica mais alarmante, em especial quando esse Poder é composto por uma elite sócio-econômica ou outro subgrupo não realmente representativo do povo, já que isso ameaça a liberdade política. Continua dizendo que dar esse poder aos juízes pode prejudicar o próprio Estado de Direito, especialmente quando o Judiciário é altamente politizado, intimidado por pressões externas, motivado por agendas particulares, corrupto ou com pouco conhecimento ou experiência.

No Brasil, com sua redemocratização de certa forma recente e sua tradição de hegemonia do Executivo ${ }^{55}$, o fortalecimento do Judiciário pode ter tido um papel importante na democratização, visto que muitos atores sociais passaram a ser legitimados a propor ações diretas e a se utilizar de remédios constitucionais ${ }^{56}$. Supõe-se, assim, que o acréscimo de poder ao Judiciário pôde conferir mais

\footnotetext{
${ }^{53}$ BARROSO, Luis Roberto. Op. cit. p. 04.

${ }^{54}$ Idem, p. 07.

${ }^{55}$ Ibidem, p. 14.

${ }^{56}$ Ibidem, p. 07.
} 
evidência aos argumentos de tais grupos, embora seja clara a necessidade de se eleger parâmetros e critérios para a prolação de decisões com alta carga moral.

Apesar da existência de peculiaridades nos diversos países e da tensão entre legalidade formal, democracia e direitos individuais, quando a expressão "Estado de Direito" é utilizada, normalmente o é com o fito de incluir os três aspectos mencionados. A confirmação desse fato vem, por exemplo, da Declaração de 1990 da Conferência sobre Segurança e Cooperação na Europa, com representantes de mais de trinta países Europeus, além dos Estados Unidos e Canadá. In verbis:

'the rule of law does not mean merely a formal legality which assumes regularity and consistency in the achievement and enforcement of democratic order, but justice based upon the recognition and full acceptance of the supreme value of the human personality and guaranteed by institutions providing a framework for its fullest expression;' and 'democracy is an inherent element of the rule of law. ${ }^{157}$

Diz Tamanaha que, enquanto a legalidade formal é o sentido dominante entre os teóricos, parece que a formulação substantiva acima enunciada é a que se aproxima do senso comum a respeito do Estado de Direito nas sociedades ocidentais (assumindo-se que existe um senso comum). Isso foi corroborado por um experimento realizado com cidadãos, conforme se verá no último capítulo. Os participantes da pesquisa, em sua maioria, entenderam apropriada uma decisão de autoridade que viola uma regra para garantir um resultado justo. Isso indica que, de acordo com os cidadãos, não basta seguir uma norma proveniente das fontes tradicionais para se ter uma decisão como legítima. Deve-se dar preferência a uma solução justa, o que significa que as questões morais e de justiça integram sua concepção de Estado de Direito.

Vistas essas manifestações e esse embate entre a visão dos cidadãos e da maioria dos teóricos mencionados por Tamanaha, serão retomados alguns argumentos a favor de uma concepção mais restrita e da formulação mais ampla, de modo a fixar alguns pontos que se entendem importantes na configuração de uma estrutura estatal legítima.

\footnotetext{
${ }^{57}$ Tradução livre: o Estado de Direito não significa meramente a legalidade formal que supõe regularidade e consistência na conquista e manutenção da ordem democrática, mas também a justiça embasada no reconhecimento e aceitação total do supremo valor da personalidade humana, garantida por instituições que fornecem a base para sua expressão integral. Democracia é um elemento inerente ao Estado de Direito. Document of the Copenhagen Meeting of the Conferernce on the Human Dimension of the CSFE, 05.06.1990 a 29.07.1990, nors. 3 and 4. Apud TAMANAHA, Brian Z. Op. cit. p. 121.
} 


\section{6}

\section{Observações Finais}

Tamanaha reconhece que uma lição pode ser extraída do pacote formado pelos três requisitos acima enunciados (legalidade formal, democracia e direitos individuais) e essa lição diz respeito ao fato de que, apesar das duas facetas antidemocráticas já informadas, o fluxo de forças políticas e sociais pode contrabalançar com sucesso o poder conferido ao Judiciário. O exemplo dado pelo autor diz respeito à invalidação, em 1930, pela Suprema Corte Norte-americana, da legislação de bem-estar social, até que o presidente Roosevelt propôs ampliar o número de integrantes da Corte para permitir o ingresso de ministros favoráveis às suas medidas. Embora tal medida não tenha sido aprovada pelo Congresso, a Corte passou a reavaliar sua prática obstrutiva das medidas presidenciais.

Embora tenha se posicionado dessa forma, o mesmo autor afirma que há riscos que não devem ser assumidos. Sob diferentes circunstâncias, a pressão pode ser realizada para se alcançar consequências antidemocráticas. E a cada vez que tal pressão tem sucesso, ela acaba por ameaçar ou encorajar outras ameaças à integridade do devido processo legal. Além disso, diz, não há uma fórmula para um balanceamento de forças que funcione de fato. No mínimo deve haver um grupo de cidadãos potencialmente ativos exercendo vigilância sobre o governo, preparado para se manifestar a favor dos direitos individuais e da democracia e da ideia de que todos, inclusive a Administração Pública, está sujeita à lei. Também deve haver uma tradição legal estabelecida no sentido de preservar a integridade da lei, aceitando que a interpretação, aplicação e incidência das regras legais é uma meta a ser atingida, comprometida com a ideia de que a elaboração e aprovação de leis é atribuição da arena política. Acima de tudo, é essencial, de acordo com Tamanaha, que os integrantes da Administração Pública compartilhem esses ideais.

Defende que a concepção substantiva não possui a neutralidade de uma visão mais restrita e, assim, cria novas áreas de discordância. Aumenta, ainda, os problemas de ambiguidade, questões contestadas e o debate sobre o significado de justiça e moralidade política. Afirma que parece ser mais difícil trabalhar, na prática, com a visão substantiva do que com a visão procedimental. Sugere que a visão substantiva é tão elástica ou tão divergente que deveria ser abandonada e 
que, se assim não for, acaba não sendo útil. Todos esses questionamentos, reflete, servem para que não seja supervalorizado o Estado de Direito ou para que não sejam adotadas ideias grandiosas a respeito de sua utilidade. Pode-se pensar que o Estado de Direito seja, assim considerado, apenas um ideal irrealizável, já que deve ser muito difícil incorporar conteúdo de maneira razoavelmente clara e operacional.

A objeção mais forte, segundo o mesmo autor, a essa concepção subjetiva do Estado de Direito diz respeito ao fato de que, em geral, aqueles que a defendem são os mesmos que esquecem a origem dessa formulação. Diz que não se pode incluir os elementos da legalidade formal, democracia e direitos individuais sob a alegação de serem necessários ou inerentes ao conceito de Estado de Direito. Afirma que, na verdade, esse é mais um senso comum da expressão, senso este que se desenvolveu só porque os três elementos em geral aparecem juntos nas democracias ocidentais liberais. Continua dizendo que as sociedades que não têm algum desses elementos não podem ser instruídas de que, para viver sob o Estado de Direito, devem implementar todo esse pacote, dando como exemplo a China, que poderia implementar a legalidade formal sem a democracia, e o Irã, que o faria sem os direitos humanos.

Se para o autor já era difícil incorporar os direitos individuais ao conceito de Estado de Direito, quanto mais os sociais: os conflitos entre os direitos sociais, individuais e a democracia aumenta muito, particularmente quando se cotejam a liberdade individual e a igualdade substantiva. Os debates a respeito dos valores sociais acabam sendo reformulados como lutas sobre o significado do Estado de Direito, esvaziando o significado dessa expressão. O Estado de Direito não precisa incluir tudo que as pessoas desejam do governo. A tentação em fazê-lo está ligada ao poder simbólico da expressão, mas, como afirma Tamanaha, não deveríamos ceder a ela.

No entanto, embora não se possa contestar muitos dos argumentos desse autor, entendemos que as concepções formais não se mostram suficientes para abarcar todos os elementos necessários para conceituar o Estado de Direito. Primeiramente, não se pode identificar o conceito de Direito com o de Estado de Direito. É certo que não há nenhum óbice à adoção do conceito de Direito como pretendem os positivistas conceituais, porque isso nada diz a respeito de como 
devem ser aplicadas as leis ou de qual conteúdo deve ter a ordem jurídica ${ }^{58}$. O conceito de Estado de Direito, entretanto, exige algo mais que isto justamente por legitimar os governos. Ela não é somente uma tese descritiva, do que no mundo dos fatos existe como Estado de Direito, mas também do que é um Estado legítimo, envolvendo implicações normativas.

Por isso, o mínimo desejável em um Estado, para que se torne legítimo, não pode se circunscrever a leis que emanem de determinada autoridade com as características de generalidade, clareza, certeza e prospectividade. O mínimo que se pode exigir de um Estado de Direito - considerando-se os fundamentos do estabelecimento de regras sociais - é que dê a todos os direito de participar, ainda que indiretamente por meio de representantes, e que proteja a vida humana e alguns direitos mínimos do ser humano. Sem a democracia e a proteção da vida o Direito perde sua razão de ser, legitimando apenas a força. Nas palavras de Castor M. M. Bartolomé Ruiz,

O direito não é justo pela força, mas pela possibilidade de promover e proteger o outro, em especial os injustiçados. Caso contrário, se torna um aparato ideológico para legitimar a força, o que torna essa força uma forma de violência. ${ }^{59}$

Jeffrey Brand-Ballard afirma que em qualquer grupo de pessoas, mesmo que no estado de natureza, existem deveres/direitos morais só pelo fato de serem seres humanos, discorrendo a respeito do dever de não maleficência, direitos “samaritanos” e direitos de justiça. Aduz que eles são elementos da moralidade comum e são reconhecidos pela maior parte das principais teorias morais, incluindo deontologia, contratualismo, consequencialismo indireto e ética das virtudes ${ }^{60}$.

Como exemplo de dever de não maleficência, pode-se referir ao dever de não usar força física contra outros seres humanos sem justificativa, ao dever de não ameaçar fazê-lo e de não ajudar outros a realizar tais atos. Dentre os direitos

\footnotetext{
${ }^{58}$ Sobre positivismo conceitual, ver STRUCHINER, Noel. Algumas 'proposições fulcrais' acerca do direito: o debate jusnaturalismo vs. juspositivismo. In Perspectivas atuais da filosofia do direito. Antonio Cavalcanti Maia, Carolina de Campos Melo, Gisele Cittadino, Thamy Pogrebinschi organizadores. Rio de Janeiro: Lumen Iuris, 2005.

${ }^{59}$ RUIZ, Castor M. M. Bartolomé. A justiça perante uma crítica ética da violência. In Justiça e memória: para uma crítica ética da violência. RUIZ, Castor M. M. Bartolomé (organizador). Unisinos, p. 108.

${ }^{60}$ Idem, p. 23.
} 
“samaritanos”, incluem-se aqueles de ajudar estranhos. Se a ajuda não tiver custos ou estes forem mínimos, então há um dever de ajudar. Esses direitos e deveres significam, segundo o autor, que outros têm o dever negativo de não usar força ou coerção para evitar que alguém aja de acordo com esses deveres ou exerça tais direitos. Os direitos de justiça significam o uso da força ou coerção para atingir objetivos de justiça. Eles constituem exceção ao dever geral de não maleficência.

Não há muita divergência a respeito do fato de que indivíduos em estado de natureza são moralmente permitidos a usar, razoavelmente, força para o objetivo de defender a si mesmos ou a outros, ao menos de agressores que estão na iminência de infligir lesão à integridade física ou a violar substancialmente o direito de propriedade. Mas muito se discute a respeito da extensão do direito de justiça. O autor continua dizendo que muitas pessoas defendem, como Locke, que há um direito de punir os maus feitores. Entretanto, isso é bastante controverso, mais que a proposição de que o direito de justiça se estende à restituição do que lhe foi tirado e à garantia de cumprimento dos acordos.

Se se passa a considerar uma sociedade com um sistema legal operante, os deveres de não maleficência e os direitos “samaritanos” são os mesmos e podem constituir o mínimo que se exige para considerar um determinado Estado de Direito. Apenas há alteração no direito de justiça, já que a utilização da força e coerção deixará de ser exercida por particulares para ser exercida pelo Estado, com exceção apenas dos casos de legítima defesa em razão de perigo atual ou iminente. Sendo assim, poderíamos apontar tais requisitos como o mínimo (mas não necessariamente o ideal) que se pode exigir para eleger como legítimo um Estado. É preciso, portanto, relembrar a razão de ser de tanta discussão a respeito do Estado de Direito. Ela decorre, como já visto, do caráter legitimante que confere aos governos e às decisões de autoridades públicas. No âmbito desse estudo, o instituto permite avaliar como apropriada ou não uma decisão judicial. E para se considerar que um governo é legítimo ou que uma decisão é apropriada, não se pode exigir apenas a adoção ou observância de um determinado procedimento, mesmo que esse procedimento seja, em teoria, democrático.

Ora, pressupõe-se que um governo tem o papel de organizar e otimizar a vida em sociedade. O fim último desse governo que criamos, portanto, não é satisfazer a ambição de poder de determinadas pessoas que se propõem a governar, mas sim garantir que as pessoas possam viver bem. Para se evitar que 
haja arbitrariedades do governante e a violação dessa finalidade, exige-se que os administradores e aqueles que criam as leis e julgam também estejam sujeitos às normas, no que chamamos de Estado de Direito.

Mas de nada adianta essa submissão à autoridade da lei se esta puder dispor contra os deveres de não-maleficência e contra os direitos "samaritanos”. Embora seja difícil o consenso a respeito do conteúdo desses direitos e deveres, há situações em que existe um senso comum que não pode ser descartado. Basta ver, por exemplo, o trabalho escravo. Difícil discordar de que esse tipo de trabalho viola o dever de não-maleficência.

Então, de nada adiantaria um conceito de Estado de Direito que legitimasse governos que maltratam seus cidadãos. Seria um conceito que não geraria tanta discordância, é fato, mas também seria vazio do ponto de vista dos fundamentos do Direito. Com esse conceito que elege requisitos mínimos não se ignora a força da conjuntura político-econômica, nem que há outras forças que podem implementar modificações sociais. A tese, nesse caso, é normativa, considerando que o papel do magistrado, conquanto possa em muitos casos não ser suficiente para realizar uma mudança visível, é uma microrrevolução que pode ao menos garantir em determinados casos concretos esses requisitos mínimos da ordem jurídica.

A respeito, ainda, do argumento de que as concepções substantivas conferem muito poder aos juízes, a ideia de “palavra final” do Judiciário, especialmente no Brasil, encontra-se mitigada por diversas constatações empíricas, que demonstram muito mais um diálogo entre as instituições do que uma prevalência da decisão judicial. ${ }^{61}$ Não bastasse isso, como no Brasil há incorporação, pela Constituição, de elementos substantivos, inclusive de direitos individuais, mesmo sob o ponto de vista do positivismo conceitual tais elementos integram o Direito do país, dada sua fonte (Assembléia Constituinte) ${ }^{62}$. Logo, a

\footnotetext{
${ }^{61}$ A esse respeito, ver MENDES, Conrado Hübner. Direitos fundamentais, separação de poderes e deliberação. São Paulo: Saraiva, 2011.

${ }^{62} \mathrm{~A}$ tese comum entre os autores considerados positivistas é apenas descritiva, denominada "positivismo conceitual”. Ela nada diz a respeito da avaliação moral das normas jurídicas válidas, apenas as identifica como provenientes de determinada fonte. Para saber mais sobre a distinção entre positivismo conceitual, positivismo ideológico, formalismo e ceticismo ético, conferir STRUCHINER, Noel. Algumas 'proposições fulcrais' acerca do direito: o debate jusnaturalismo vs. juspositivismo. In Perspectivas atuais da filosofia do direito. Antonio Cavalcanti Maia, Carolina de Campos Melo, Gisele Cittadino, Thamy Pogrebinschi organizadores. Rio de Janeiro: Lumen Iuris, 2005.
} 
opção por tais direitos em detrimento de determinada regra poderia ser vista não em função do conceito de Estado de Direito que se adota, mas antes do conceito de Direito que se tem. Existe uma diferença essencial nesse ponto, porque o conceito de Estado de Direito, segundo as suas diversas concepções teóricas, permite que se decida contra o Direito de um país se ele não contemplar esses direitos mínimos que mencionamos anteriormente. Já a incorporação, pela ordem jurídica de um país, desses elementos essenciais mencionados importa em decidir conforme o ordenamento, não contrariamente a ele.

Assim, para que um Estado seja considerado legítimo, ele tem de incorporar alguns elementos mínimos, quais sejam, a legalidade formal, a democracia e o dever de não maleficência, os direitos samaritanos e os direitos de justiça (esses últimos operados pelo próprio Estado e na vertente mais restrita, de fazer cumprir os acordos e de restituição do que foi subtraído a alguém). A dificuldade em se conceituar esses elementos não pode ser considerada óbice à adoção dessa concepção substantiva, porque não se poderia legitimar um Estado que faça mal aos seus governados ou a parte deles. Por outro lado, embora esses elementos sejam necessários, não precisam ser suficientes, já que há muitos ganhos em se incorporar à ordem jurídica os demais direitos, inclusive os sociais.

Resumindo, embora a expressão "Estado de Direito” tenha a característica de conferir legitimidade ao exercício do poder estatal, inclusive judicial, nos países contemporâneos, notou-se que ela é utilizada, muitas vezes, em sentidos conflitantes. Os principais significados atribuídos à expressão podem ser classificados em formais e substantivos, sendo os primeiros mais restritos e os segundos mais amplos, incluindo, além dos requisitos de forma, os de conteúdo.

As concepções formais apenas exigem que o Direito tenha sido estabelecido por uma autoridade (Direito pelo Estado), ou que, além disso, as leis sejam prospectivas, genéricas, claras, públicas e relativamente estáveis (legalidade formal) ou que também sejam aprovadas por um procedimento democrático (correntes democráticas). As formulações substantivas importantes para a compreensão da pesquisa empírica do último capítulo incluem, no conceito, direitos individuais, relevando notar que as mais amplas aduzem os direitos sociais.

Criticam-se as concepções mais abrangentes alegando que esses requisitos de conteúdo são conflitantes com a noção de Estado do Bem-estar Social. 
Entretanto, foi visto que muitos países que adotaram tal tipo de configuração institucional também adotavam o Estado de Direito, concluindo-se que não há, entre um e outro, incompatibilidade. No caso do Brasil, embora o país não tenha adotado o Estado do Bem-estar Social como os países desenvolvidos, houve incorporação pela Constituição de 1988 de direitos sociais que não são considerados incompatíveis ou excludentes dos individuais.

Outra crítica aos requisitos de conteúdo ocorre por conferirem muito poder àqueles que atuam no âmbito do Judiciário, como advogados e, especialmente, os juízes. Nesse sentido, haveria uma implicação antidemocrática, já que os juízes não são eleitos. A esse argumento responde-se utilizando a ideia de que há um significado evidente dos direitos e que esse significado é apreendido pelos magistrados e expresso em suas decisões; ou responde-se com base na afirmação de que os juízes recorrem à sociedade para encontrar os princípios que prevalecem ou, por fim, com fundamento na alegação de que, dada a divergência a respeito das questões morais, o juiz de fato realiza uma escolha, escolha essa inevitável dadas as características do sistema jurídico, mas que deve levar em consideração todos os dados disponíveis.

Afirma-se que a importância desse poder ser conferido a órgãos não eleitos ocorre em razão da necessidade de proteção das minorias, que inclusive podem se utilizar do ambiente judicial para ver prevalecer em algumas situações sua visão dos direitos não contemplada pela decisão da maioria, cuja visão é implementada por força política. Por fim, a formulação substantiva também é defendida por garantir condições mínimas para que a própria democracia seja exercida, com igual participação e respeito.

Esses argumentos são criticados por Tamanaha, que declara que o conceito de Estado de Direito não precisa ser tão amplo, sendo mais funcional se restrito, aduzindo ainda que há muita discordância a respeito dos direitos morais. Logo, continua, deixar para os juízes a definição do que deve prevalecer significa transferir para um terceiro não eleito poderes que pertencem aos cidadãos.

A opção desse trabalho, pelos requisitos substantivos enunciados por Jeffrey Brand-Ballard, se dá, como afirmado, em razão de serem comuns à maior parte das principais teorias morais. Sendo elementos sobre os quais há um certo consenso e, ainda, que estabelecem um estado de coisas básico tendo em vista a condição humana, entende-se que não se poderia legitimar um Estado sem eles. 
Para os fins a que se propõe esse estudo, porém, essa posição não é tão relevante. O mais importante para a compreensão da pesquisa empírica é reconhecer que, de acordo com as concepções substantivas do Estado de Direito, se, para ser legítimo, um Estado deve incorporar em seu Direito determinado conteúdo, como defendem as correntes substantivas, então supõe-se que o Judiciário, como integrante desse Estado, também deva observar esses argumentos de conteúdo, utilizando, na fundamentação de suas decisões, razões de substância ${ }^{63}$. Isso significa que a decisão judicial seria apropriada, do ponto de vista do Estado de Direito substantivo, se deixasse de aplicar uma regra que violasse, por exemplo, algum direito individual. Como os ideais de justiça se confundem com a noção de Estado de Direito nas correntes substantivas estudadas, a decisão que faça prevalecer o direito individual e social violado privilegia a justiça do resultado em detrimento da aplicação estrita da lei.

Por outro lado, se um Estado legítimo é aquele cujo Direito deve observar apenas requisitos formais, então deduz-se que os juízes não poderiam, legitimamente, deixar de aplicar uma regra que obedeça aos requisitos formais já enunciados. Isso quer dizer que, nos casos ditos claros, mas que também comportam uma avaliação moral, porque a aplicação da regra produz um resultado injusto, a amplitude do conceito de Estado de Direito poderá influenciar a legitimidade de uma decisão que abarque o argumento moral, superando o jurídico estrito.

Conforme se pode observar, para a análise dos dados empíricos no último capítulo, levam-se em consideração as visões mais amplas de Estado de Direito Substantivo, que incluem no mínimo os direitos individuais. Não a visão que elege apenas a necessidade de se garantir deveres de não-maleficência e direitos samaritanos e de justiça. A consideração desses elementos ocorreu apenas para se

\footnotetext{
${ }^{63}$ Struchiner e Schecaira distinguem argumentos jurídicos (ou de autoridade) dos morais (ou de substância), como será visto no próximo capítulo, considerando que a primeira é aquela considerada institucional, amplamente baseada em regras que fornecem razões de autoridade (STRUCHINER, Noel e SHECAIRA, Fábio Perin. A distinção entre direito e moral e a distinção moral do direito. In RDE Revista de Direito do Estado. Ano 7, $\mathrm{n}^{\circ}$ 22. Rio de Janeiro: Renovar, jan/mar 2012, pp.131-145; p. 137). Já a argumentação moral diz respeito à adução de razões de substância (consequencialistas e deontológicas), muitas vezes fundadas em princípios (STRUCHINER, Noel e SHECAIRA, Fábio Perin. Op. cit. p. 136 e 142. Segundo os autores, o julgamento moral às vezes está embasado em justificativas que levam em consideração as consequências da decisão - razões consequencialistas - e, outras vezes, está calcado em argumentos de caráter deontológico, com preponderância das emoções - razões deontológicas).
} 
tomar uma posição na discussão conceitual sobre o instituto, sem maiores relevâncias práticas para a pesquisa de campo, a qual se embasou na concepção substantiva que inclui direitos individuais.

A proposta de cunho normativo que envolve a concepção de Estado de Direito é importante não só para se compreender o experimento descrito no último capítulo, mas também para se observar que há bons argumentos a favor da obediência irrestrita das regras e também da sua superação para garantir a prevalência de um resultado justo, que preserve determinado direito subjetivo. Analisado esse debate, segue-se a análise dos tipos de argumentos utilizados para se perseguir um ou outro ideal, o formal ou o substantivo, e a relação desses argumentos com uma prática decisória que tende ao formalismo ou ao particularismo, estudando esses últimos conceitos e situando o aparecimento da sobreinclusão e subinclusão na Justiça do Trabalho. 


\section{3 \\ Decisão judicial}

Da análise predominantemente normativa do capítulo anterior, passa-se àquela que prioriza o aspecto descritivo, de como os juízes decidem os casos que lhes são submetidos. Já se constatou que as formulações mais restritas de Estado de Direito acabam por levar à defesa de uma prática decisória que privilegia a regra jurídica decorrente das fontes formais e que as concepções mais amplas implicam em considerar legítimas decisões que superam a regra para garantir a aplicação de um determinado direito e de um resultado justo. Assim, neste capítulo estuda-se quais são os tipos de argumentos utilizados para fundamentar uma ou outra solução judicial do litígio, além de buscar entender como se processa a decisão.

Parte-se, pois, da classificação dos argumentos em jurídicos ou de autoridade e morais ou de substância, para depois analisar em que medida é possível a utilização estrita de argumentos de autoridade, ao menos na Justiça do Trabalho. Após constatar que, na Justiça do Trabalho, muitas são as situações em que há necessidade de recurso aos argumentos de substância, identificam-se a sobreinclusão e subinclusão, que serão objeto de estudo empírico no último capítulo, tanto em abstrato quanto em concreto.

Para traçar essa linha de raciocínio, recorre-se aos argumentos de Hart a respeito do realismo jurídico e do formalismo, que revelam que no Direito há inevitáveis momentos de escolha por parte daquele que o aplica e também há um conjunto de regras suficientemente determinadas para permitir que as pessoas sigam suas vidas sem, por vezes, ter de recorrer ao Judiciário.

Observe-se são utilizados dois conceitos de formalismo jurídico no presente estudo. O primeiro diz respeito àquele criticado por Hart e sua importância se encontra na crítica que lhe é feita, porque os argumentos utilizados convencem a respeito da incapacidade do Direito em dar respostas determinadas sempre. E o segundo é concernente àquele defendido por Schauer e Struchiner, sendo este levado em consideração para analisar os resultados do experimento realizado com juízes e descrito no último capítulo. 


\section{1}

\section{Tipo de Argumentação Utilizada}

A argumentação, ou atividade de aduzir razões contra ou a favor de uma tese ou proposição ${ }^{64}$, pode ser teórica (também chamada especulativa) ou prática. A primeira diz respeito à colocação de razões para sustentar que uma proposição descritiva é verdadeira ou falsa. No campo da ciência, os cientistas utilizam razões para defender a verdade ou falsidade de uma determinada hipótese, com base em evidências produzidas por seus experimentos. No Direito, esses tipos de argumentos podem ser utilizados para se sustentar que um fato é verdadeiro ou falso. Por exemplo: o argumento de existência de um laudo pericial que conclua que a digital deixada na arma do crime é de uma determinada pessoa que está sendo acusada de cometê-lo. Esse é um argumento teórico que defende ser verdadeira a hipótese de que aquela pessoa cometeu o ilícito penal.

No que se refere à argumentação prática, ela diz respeito à adução de razões para se fazer ou deixar de fazer algo ou para sustentar opiniões do que pode ou deve ser feito. No campo do Direito, as pessoas utilizam a argumentação teórica para dela extrair inferências práticas. Por exemplo, da deliberação do Legislativo a respeito da existência ou inexistência de determinada prática imoral pode surgir uma resolução segundo a qual uma norma geral deve ser promulgada.

A argumentação prática, relacionada ao dever ser, pode ser pura ou institucional. A primeira é aquela que ocorre livre de amarras institucionais específicas. Considerando-se o modo altamente institucionalizado de organizarmos o mundo, talvez ela não exista de fato, mas ela pode ser extraída da conversa de bar e da crítica realizada na academia ${ }^{65}$.

Nesse contexto, dois tipos de argumentos “puros” considerados legítimos podem ser utilizados. Os primeiros são os teleológicos ou consequencialistas, ou seja, aqueles que versam a respeito das consequências de determinada conduta para aferir se ela deve ou não ser realizada. Os segundos são os deontológicos, que são os que versam sobre o valor inerente de determinada conduta, se é certa ou errada, se é justa ou injusta, independente das consequências. Esses dois tipos

\footnotetext{
${ }^{64}$ STRUCHINER, Noel e SHECAIRA, Fábio Perin. A distinção entre direito e moral e a distinção moral do direito. In RDE Revista de Direito do Estado. Ano 7, nº 22. Rio de Janeiro: Renovar, jan/mar 2012, p. 132.

${ }^{65}$ Idem, p. 134.
} 
são chamados de "argumentos de substância"66 e são válidos independentemente de sua fonte, consagrando as duas principais categorias de argumentos morais.

Os argumentos morais (ou argumentos práticos puros) são utilizados por pessoas comuns e, especificamente, pelos filósofos morais para defender suas concepções. O exemplo dado por Struchiner e Shecaira é aquele que diz respeito aos dois cenários dos bondinhos desgovernados, desenvolvidos respectivamente por Phillippa Foot ${ }^{67}$ e Judith Jarvis Thomson ${ }^{68}$. No primeiro caso, um bondinho desgovernado segue em direção a cinco pessoas presas no trilho. Para evitar que ocorra o atropelamento, é necessário acionar uma alavanca, para que o bondinho pegue um trilho secundário. Entretanto, nesse trilho secundário tem uma pessoa presa. É moralmente correto acionar a alavanca? A maior parte das pessoas entendem que é correto, com base em um argumento consequencialista: serão salvas mais pessoas.

No segundo cenário, um bondinho desgovernado está prestes a atropelar cinco pessoas presas no trilho. Entretanto, em cima de uma ponte, na sua frente, há um homem suficientemente pesado para parar o bondinho antes que ele atropele aquelas pessoas. Para tanto, você precisa empurrá-lo. Você não tem massa suficiente para parar o bondinho e a única forma de impedir que o atropelamento das cinco pessoas aconteça é empurrando o homem na sua frente. É moralmente correto empurrá-lo? Nesse caso, a maior parte das pessoas responde que não, com base em justificações deontológicas: não é correto tirar a vida de alguém, mesmo que seja para salvar um número maior de pessoas. Foca-se na conduta e não nas consequências.

Vimos a argumentação prática pura, que se utiliza de argumentos consequencialistas e deontológicos. A argumentação prática institucional é aquela em que são utilizados argumentos de autoridade. Para se fazer ou deixar de fazer algo, faz-se referência a alguém que possua autoridade e que tenha estabelecido

\footnotetext{
${ }^{66}$ Idem, p. 134.

${ }^{67}$ FOOT, Phillippa. The problem of abortion and the doctrine of the double effect. In Virtues and vices and other essays in moral philosophy, 2002, p. 19. Apud STRUCHINER, Noel e SHECAIRA, Fábio Perin. A distinção entre direito e moral e a distinção moral do direito. In RDE Revista de Direito do Estado. Ano 7, $\mathrm{n}^{\circ}$ 22. Rio de Janeiro: Renovar, jan/mar 2012, p. 135.

${ }^{68}$ THOMSON, Judith Jarvis. The trolley problem. Yale Law Journal 94, 1995, p. 1.395-415. Apud STRUCHINER, Noel e SHECAIRA, Fábio Perin. A distinção entre direito e moral e a distinção moral do direito. In RDE Revista de Direito do Estado. Ano 7, $\mathrm{n}^{\circ} 22$. Rio de Janeiro: Renovar, jan/mar 2012, p. 135.
} 
uma regra a respeito. Um argumento institucional ou de autoridade muitas vezes prevalece sobre um argumento moral. Nas palavras dos referidos autores:

Levar as regras (e as razões geradas por elas) a sério significa, como condição mínima, que elas podem oferecer um alto grau de resistência às razões de substância que seriam invocadas na ausência das regras. Quando regras são levadas no auge da seriedade, elas são capazes de suprimir e suplantar as razões de substância (teleológicas e deontológicas) que governariam as decisões, não fosse pela sua existência." 69

Struchiner e Schecaira acreditam que a argumentação jurídica típica utilizadas pelos juízes e advogados em casos de rotina e ensinada pelas faculdades de Direito - seja institucional, pois há referência a razões de autoridade, que derrotam as razões substantivas consequencialistas e deontológicas que prevaleceriam em outros contextos. No âmbito da decisão judicial, portanto, prevaleceria a utilização de argumentos de autoridade (chamados jurídicos), não os práticos puros (morais). Contudo, quando há necessidade de referência a princípios constitucionais, essa referência não poderia vir acompanhada de razões de autoridade apenas, já que, para isso ser suficiente, é necessário que o conteúdo do texto seja tal que o recurso a razões substantivas (consequencialistas ou deontológicas) seja impedido ou significativamente limitado.

Como os mencionados autores fazem referência aos princípios como enunciados gerais e vagos, em virtude dos conceitos morais que incorporam, então temos que, de fato, não há clareza suficiente da norma para se impedir o recurso a razões de substância. Em muitos casos, deve-se recorrer a uma teoria moral para justificar o enquadramento de uma situação concreta em um princípio, cuja vagueza não permite a subsunção direta.

Os autores afirmam que não estão defendendo que toda aplicação de princípio descaracterize a qualidade jurídica da argumentação. O princípio pode já ter sido regulamentado por lei ou os próprios juízes podem já ter enfrentado a situação e delineado seu contorno por meio de reiteradas decisões que utilizam argumentos morais, formando uma jurisprudência que sirva como uma razão de autoridade. Quando não há lei ou jurisprudência, portanto, questionam como pode uma norma impedir o recurso a tais considerações [substantivas] quando ela

\footnotetext{
${ }^{69}$ Ibidem, p. 136.
} 
inclui conceitos morais cuja vagueza as convida enfaticamente ${ }^{70}$. Indicam, portanto, que a argumentação nesse caso deve incluir argumentos deontológicos ou consequencialistas. De todo modo, defendem que, entre a possibilidade de se adotar uma regra institucional ou um princípio, o melhor é que se adote a primeira.

Dizem, ainda, que a regra é considerada “grosseira”. Isso porque é dotada de autoridade, impondo limites ao raciocínio prático. Ela entra no lugar das nossas considerações valorativas, afastando nossa deliberação sobre a totalidade de razões de substância que consideramos relevantes para a decisão. Caso contrário, seria mera recomendação, não regra. Também é grosseira porque constitui uma generalização simplificada de considerações de substância. O exemplo dado pelos autores é aquele do limite de velocidade, fixado pela regra em, ilustrativamente, oitenta quilômetros por hora. Isso entra no lugar de a regra dispor "dirija prudentemente” ou "proteja a vida”. Pode-se dizer que a regra descreve um comportamento, simplificando as considerações de substância; não estabelece, como o princípio, um estado de coisas a ser alcançado.

Desse modo, defende-se que a remição a regras é preferível, em razão da busca da certeza, segurança e previsibilidade. Como a linguagem das regras é mais precisa, dando respaldo a uma argumentação preferencialmente jurídica, de sua constante aplicação pode-se extrair, segundo os mencionados autores, uma coordenação e estabilidade maiores, além de permitir uma maior eficiência, eis que a referência às mesmas poupa recursos de tempo e dinheiro com discussões morais.

Além disso, respeita-se a separação de poderes e a vontade do povo, expressa por meio do Legislativo eleito. Continuam dizendo que a possibilidade de erros é muito maior quando se opta por uma argumentação moral, já que os juízes não são Hércules nem são especialistas em questões morais. E a reiteração de decisões que afastam a regra com base em argumentos morais pode gerar um efeito sistêmico, de fazer com que outras pessoas (juízes ou agentes da Administração Pública, por exemplo), realizem movimento similar em casos que não deveriam, do ponto de vista moral, receber o mesmo tratamento. Por exemplo, se houvesse uma decisão da Administração Pública que cancelasse uma política

\footnotetext{
${ }^{70}$ Ibidem, p. 139.
} 
de vacinação para realizar um fundo de reserva para pagamento de caríssimos remédios demandados por um grupo pequeno de pessoas no Judiciário.

Difícil discordar de argumentos tão sólidos. Entretanto, há um ponto que nos leva ao questionamento e que está relacionado ao contexto em que se insere o estudo empírico descrito no último capítulo. Uma das premissas utilizadas pelos autores é a de que a argumentação jurídica típica é aquela utilizadas pelos juízes e advogados em casos de rotina e ensinada pelas faculdades de Direito. Será que de fato na rotina é possível a utilização preponderante de argumentos jurídicos, deixando de lado as razões de substância? Analisaremos a questão no âmbito na Justiça do Trabalho, já com o foco que a pesquisa de campo demanda.

Essa análise é importante para se aferir o contexto em que aparece a tensão entre o justo e o legal estudados empiricamente. Portanto, caminha-se no sentido de investigar se na rotina judiciária trabalhista é possível na prática que prevaleçam as razões de autoridade, para então conceituar a sobreinclusão e subinclusão, que emergem nesse cenário e que serão objeto dos questionários aplicados aos juízes. Para estudar a premissa em tela, de que há possibilidade de prevalência rotineira dos argumentos jurídicos, parte-se da compreensão de como se processam as decisões judiciais, inciando a investigação pela corrente teórica denominada Realismo Jurídico, que surgiu nos Estados Unidos na década de 1930 e que estuda a decisão judicial. Essa teoria afirma que na verdade só na aparência a decisão judicial utiliza argumentos jurídicos, porque outros são os fatores que levam à solução do caso.

De outro lado, o positivismo ideológico defende que os juízes (e os demais sujeitos jurídicos) têm uma obrigação moral de obedecer ao direito positivo, devendo aplicar uma regra só pelo fato de ser jurídica, de provir de uma fonte válida, independente de seu conteúdo ${ }^{71}$. Haveria, portanto, utilização estrita de razões jurídicas. Os formalistas diriam que isso é factível dado que o sistema de normas que integra o direito é fechado (incluindo apenas as normas aprovadas pelo Legislativo), completo (não há lacunas), consistente (inexistem contradições e conflitos entre as normas) e preciso (a linguagem é clara, negando-se as

\footnotetext{
${ }^{71}$ STRUCHINER, Noel. Algumas 'proposições fulcrais' acerca do direito: o debate jusnaturalismo vs. juspositivismo. In Perspectivas atuais da filosofia do direito. Antonio Cavalcanti Maia, Carolina de Campos Melo, Gisele Cittadino, Thamy Pogrebinschi organizadores. Rio de Janeiro: Lumen Iuris, 2005, p. 406.
} 
indeterminações linguísticas) ${ }^{72}$.

Por isso, inicialmente analisaremos um pouco dos estudos realistas para depois apresentarmos o contraponto de Hart ao realismo e ao formalismo e tentar esboçar uma forma de compreender o que de fato ocorre nas decisões judiciais trabalhistas, para passar depois ao estudo do caso referência.

Não é nossa pretensão dar uma resposta definitiva à questão de se, realmente, prevalece a utilização de argumentos jurídicos na prática rotineira dos tribunais, mas apenas aduzir alguns argumentos sobre a matéria, numa tentativa de enriquecer o debate.

Uma pesquisa realizada por Armando Castelar Pinheiro com 741 juízes, publicada em dezembro de 2002, ao pesquisar as razões da "falta de previsibilidade” das decisões judiciais, constatou que a maioria dos juízes não percebia como frequente em suas atividades profissionais a "judicialização da política”, tida como a tendência dos poderes políticos transferirem para o Judiciário a solução de conflitos políticos ${ }^{73}$. Somente $8,5 \%$ entendeu como muito frequente o ônus de decidir sobre questões de caráter essencialmente político, 33,6\% consideraram frequente essa circunstância e 38,2\% reconheceu que esse fato ocorre ocasionalmente. Notou-se que 29,8\% dos magistrados participantes do estudo afirmaram que as deficiências do ordenamento legal e jurídico são muito relevantes para explicar a falta de previsibilidade das decisões judiciais.

Ainda menos frequente foi considerado pelos magistrados o fenômeno da “politização” das decisões judiciais, entendida como utilização de visões políticas pessoais do juiz como base de suas decisões em detrimento da interpretação “rigorosa” da lei. Observou-se que 3,9\% dos entrevistados respondeu que isso é muito frequente, $20,2 \%$ que é frequente, sendo que a maioria dos entrevistados (50,2\%) declarou que isso ocorre apenas ocasionalmente.

Essa pesquisa lança uma luz sobre a referida premissa ao indicar que os

\footnotetext{
${ }^{72}$ Idem, p. 408. Note-se que não se utiliza aqui o conceito de formalismo dado por Schauer (Thinking like a lawyer: a new introduction to legal reasoning. Londres: Harvard University Press, 2009, pp. 29-35). Para este autor, o Direito não é sempre completo e determinado. Mas, quando há uma regra clara, o formalismo conforme conceituado por Schauer se compromete a aplicá-la mesmo que o resultado seja subótimo. Não é contra esse formalismo, portanto, que se posiciona o estudo, mas sim contra aquele referido no corpo do trabalho.

${ }^{73}$ Judiciário, reforma e economia: a visão dos magistrados. p. 40. Disponível em $<$ http://www.febraban.org.br/Arquivo/Destaques/armando_castelar_pinheiro2.pdf $>$. Acessado em 07.02.2014.
} 
casos difíceis, que envolvem escolhas políticas, não são a maioria. Também pode ser que os juízes não apresentem uma autopercepção fidedigna sobre o que efetivamente fazem. De todo modo, não se toca no ponto principal ora investigado, que é o de saber se na rotina judicial é possível a utilização preponderante de razões jurídicas ou de autoridade. O estudo desse ponto, como visto, é importante para levar à apreensão do cenário em que se desenvolve o debate particularista e formalista, no intuito de compreender melhor os resultados da pesquisa empírica (questionário) realizada para aferir se, nos casos claros que comportam uma avaliação moral, prevalece um ou outro tipo de argumentação nas decisões judiciais.

\section{2}

\section{O Realismo Jurídico}

Como visto, o Realismo surgiu nos Estados Unidos, na década de 1930, existindo também alguns traços da teoria na Alemanha, no final do século XIX, início do XX, e no trabalho contemporâneo de Fraçois Geny, na França. Embora haja quem conceba o Realismo como uma teoria do Direito, preocupada com o conceito de Direito, esse estudo se filia à corrente que o enxerga como uma teoria da decisão judicial, que foca no trabalho dos juízes sua análise.

Os realistas são céticos em relação à ideia de que a aplicação do Direito diz respeito apenas a um processo lógico-dedutivo em que a premissa maior é a regra, a premissa menor é o caso, daí extraindo-se uma conclusão única (silogismo), numa argumentação tipicamente institucional e jurídica.

Oliver Wendell Holmes, autor da frase “As profecias sobre o que os tribunais farão de fato, e nada mais pretensioso, são aquilo que quero dizer com direito”, é um antecessor do Realismo ${ }^{74}$. Ele defende que as decisões dos tribunais normalmente se embasam nas fontes tradicionais do Direito, mas, no que se refere às mudanças na common law, os juízes acabam por realizar escolhas políticas, de acordo com suas experiências. Não há, segundo ele, descoberta das mudanças do Direito a partir de um processo de dedução lógica. Essa parte final era uma ideia inovadora para a época, que não via as alterações da common law como um ato criativo dos tribunais.

\footnotetext{
${ }^{74}$ SCHAUER, Frederick. Thinking like a lawyer: a new introduction to legal reasoning. Londres: Harvard University Press, 2009.
} 
Os estudos de Holmes foram precursores do realismo propriamente dito. Dois expoentes dessa corrente doutrinária, Jerome Frank e Hutcheson, desenvolveram a ideia de que os tribunais, ao contrário do que se pensava na época, partem do caso concreto (não da regra), formulam uma decisão intuitiva e, depois, se socorrem das fontes tradicionais de Direito para encontrar uma regra que se amolde à decisão já formulada. Desse modo, a argumentação jurídica seria utilizada apenas na aparência, porque os reais fatores de decisão seriam outros.

Para formular essa decisão “intuitiva”, os realistas afirmam que os juízes se embasam em elementos extrajurídicos, como por exemplo, um palpite, seus atributos pessoais ou os atributos dos litigantes, suas convicções políticas, aspectos psicológicos ou até mesmo normas extrajurídicas (ilustrativamente, a máxima eficiência e as melhores consequências econômicas). Somente pela pesquisa empírica seria possível descobrir quais são os reais fatores que levam à tomada de decisão.

Importante que se entenda que o Realismo não se distingue das demais teorias a respeito da decisão judicial porque enfatiza os fatos em detrimento das regras. A distinção está na circunstância de considerarem que o juiz determina quais fatos são relevantes e qual decisão é mais apropriada por fatores outros que não a lei. Em oposição aos realistas, temos os que consideram que o juiz olha para as regras para aferir tanto quais fatos são relevantes quanto para determinar qual decisão é indicada para esses fatos.

A conclusão realista é de que o relacionamento entre as fontes tradicionais do Direito e a decisão seria fraco; somente a pesquisa empírica seria capaz de revelar os critérios efetivamente utilizados para a decisão, critérios esses que seriam extralegais.

Há um outro dado que, segundo os realistas, reforça a sua tese. Ele diz respeito ao fato de que, em geral, é possível achar um fundamento legal para uma decisão a favor do autor ou do réu. Há cânones interpretativos conflitantes e que possibilitam a tomada de decisão num ou noutro sentido. Na maior parte das vezes, portanto, é possível justificar a decisão “intuitiva” com base nas fontes tradicionais do Direito. Quando o caso não comporta dúvida, raramente seria levado ao Judiciário. Sendo assim, para o Realismo Jurídico, as regras legais não impõem limites às decisões como os formalistas supõem. Isso poderia significar que a aparência jurídica dos argumentos - mesmo na pesquisa empírica - estaria 
encobrindo seu caráter extrajurídico e, por vezes, substancial. No entanto, essa é uma visão extremada, que não pode ser generalizada, como veremos a seguir.

\section{3}

\section{Críticas ao Realismo e ao Formalismo}

Iniciaremos pelas críticas de Hart. Esse autor critica tanto o formalismo quanto o realismo jurídico. Vale relembrar que por formalismo jurídico tem-se a corrente que sustenta duas teses: (1) que o direito é formado por normas aprovadas pelo Legislativo, excluindo-se os costumes e a jurisprudência e (2) que o sistema de normas que integra o direito é fechado (incluindo apenas as normas aprovadas pelo Legislativo), completo (não há lacunas), consistente (inexistem contradições e conflitos entre as normas) e preciso (a linguagem é clara, negandose as indeterminações linguísticas) ${ }^{75}$.

De uma breve análise da linha de raciocínio de Hart, importante para se compreender sua crítica, observa-se que, a respeito das fontes normativas tradicionais, ele inicia sua explanação afirmando que há duas formas principais de comunicação de padrões gerais de conduta: a legislação e o precedente. A legislação tem a pretensão de ser geral e abstrata e resolver, segundo subsunção do caso concreto à regra, as situações conflituosas. Entretanto, esse silogismo soluciona apenas casos claros. Os limites inerentes à natureza da linguagem e a incapacidade humana de antecipar o futuro faz com que haja casos não previstos e em que apenas parte dos aspectos coincidem com aqueles explicitados na regra. Esses são os casos incertos.

Os precedentes remetem a um caso exemplar que já foi decidido, devendo os demais serem decididos no mesmo sentido. Há, nesse caso, um número maior de dúvidas. Não se sabe com exatidão quais são os aspectos relevantes do exemplo que devem servir de base para aplicação da mesma solução. Tanto num quanto noutro, observa-se se o caso presente se assemelha suficientemente ao caso descrito (ou exemplo), em aspectos relevantes, de acordo com a finalidade da regra. Quanto maior o número de casos incertos resolvidos, mais se individua a

\footnotetext{
${ }^{75}$ STRUCHINER, Noel. Algumas 'proposições fulcrais' acerca do direito: o debate jusnaturalismo vs. juspositivismo. In Perspectivas atuais da filosofia do direito. Antonio Cavalcanti Maia, Carolina de Campos Melo, Gisele Cittadino, Thamy Pogrebinschi organizadores. Rio de Janeiro: Lumen Iuris, 2005.
} 
finalidade da proposição jurídica.

Essa zona de incerteza é chamada, por Hart, de "textura aberta” da norma, sendo que, para solucioná-la, a legislação pode realizar uma delegação administrativa de regulamentação ou deixar aos indivíduos que ponderem os interesses envolvidos, de forma a obter um equilíbrio razoável entre as pretensões sociais, sujeitos, porém, à retificação posterior pelo tribunal.

Continua dizendo que o não reconhecimento dessa zona de incerteza no Direito acaba por disfarçar e minimizar a necessidade de escolha, inerente a qualquer ordem jurídica. Significa enfatizar certeza e previsibilidade às custas das peculiaridades que inicialmente ignoramos.

Observe-se, diz o autor, que, no caso do precedente inglês, não há um método único de extração da regra a partir da decisão judicial e que não há apenas uma formulação possível ou correta. Além disso, os tribunais podem interpretar de forma restritiva ou ampliativa a regra extraída do precedente, o que, mais uma vez, revela a existência de casos difíceis ou de solução incerta.

Embora assim seja, o sistema inglês produziu, pelo seu uso, um corpo de regras com precisão equiparável às regras legisladas, em razão de um consenso geral formado. O produto final desse sistema é, portanto, a regra, enquanto que, na legislação, a regra constitui a estrutura do sistema, do que se conclui que, em qualquer deles, as regras ocupam um lugar central. O sistemas jurídicos revelam, portanto, um compromisso entre segurança e previsibilidade, por um lado, e abertura, por outro.

O entendimento de que o Direito seria formado apenas pelas decisões judiciais, segundo Hart, não se sustenta, já que, para se reconhecer que o Judiciário pode proferir a decisão, tem-se que reconhecer que há uma regra que lhe atribui essa autoridade (regra secundária que confere jurisdição a uma sucessão mutável de indivíduos). Há, portanto, uma inconsistência, porque pelo menos a regra de reconhecimento (aqui chamada de secundária) tem de ser reconhecida como tal. Mesmo para as versões mais moderadas do Realismo, que reconhecem somente a existência dessas regras, poder-se-ia argumentar que aquelas que instituem o Legislativo também são regras, não diferindo das primeiras.

Até no caso das regras primárias, ou seja, aquelas que exigem que se faça ou 
se abstenha de fazer alguma coisa ${ }^{76}$, nota-se que as pessoas convivem na sociedade reconhecendo as regras como padrão jurídico de comportamento, referindo-se a elas em suas relações cotidianas e as utilizando de forma normativa. Justifica-se o comportamento com referência à regra e critica-se quem não a obedece. Há, portanto, uma internalização desses padrões gerais de conduta ${ }^{77}$. Nas palavras do referido autor:

os indivíduos efectivamente mostram toda a série de condutas e atitudes que designamos como o ponto de vista interno. $\mathrm{O}$ direito funciona nas vidas deles, não meramente como hábitos ou como base de predição de decisões dos tribunais ou de acções de outras autoridades, mas como padrões jurídicos de comportamento aceites. Quer dizer, não só fazem com regularidade tolerável o que o direito lhes exige, mas encaram-no como um padrão de conduta jurídico, referem-se a ele quando criticam os outros ou quando justificam exigências e quando admitem as críticas e exigências feitas por outros. (...) É seguramente um facto observável da vida social, que os indivíduos não se limitam ao ponto de vista externo, anotando e prevendo as decisões dos tribunais ou a incidência provável de sanções. Ao contrário, exprimem continuadamente em termos normativos a sua aceitação partilhada do direito como um guia de conduta. ${ }^{78}$

Nos casos de “textura aberta”, sem dúvida que os particulares só podem prever como os tribunais irão decidir e ajustar seu comportamento em conformidade. Como não existe uma regra clara e determinada sobre a situação, também não existe, por consequência, um padrão geral internalizado nos cidadãos. Daí que se pode pensar em prever o que os juízes irão decidir a respeito.

Diz Hart que o cético é, por vezes, uma pessoa que pretendia que o sistema jurídico desse respostas únicas para todas as questões, respostas essas resultantes de um processo lógico dedutivo que parte das fontes tradicionais do Direito. Ao constatar que isso de fato não acontece, acaba por resvalar para o outro extremo, dizendo que as regras não vinculam. Hart considera evidente o esforço dos tribunais de obediência às regras (ou, então, de fundamentação das decisões com

\footnotetext{
${ }^{76}$ HART, Herbert. Op. cit. p. 91.

${ }^{77}$ Hart discorre a respeito do aspecto "interno" das regras, afirmando que Quando um hábito é geral num grupo social, esta generalidade constitui simplesmente um facto relativo ao comportamento observável na maior parte do grupo. Para que haja um tal hábito, não se exige que nenhum dos membros do grupo pense, de qualquer modo, no comportamento geral ou saiba sequer que o comportamento em questão é geral; ainda menos se exige que se esforcem por ensiná-lo ou que tencionem mantê-lo. Basta que cada um, por seu lado, se comporte da forma que os outros também se comportam efectivamente. Pelo contrário, para que uma regra social exista, alguns membros, pelo menos, devem ver no comportamento em questão um padrão geral a ser observado pelo grupo como um todo. Uma regra social tem um aspecto 'interno' para além do aspecto externo que partilha com o hábito social e que consiste no comportamento regular e uniforme que qualquer observador pode registrar. Op. cit. p. 65.

${ }^{78}$ Op. cit. p. 151.
} 
base nelas, mesmo que a solução tenha sido obtida por outros fundamentos). Isso não significa, porém, a prevalência de uma argumentação institucional ou jurídica.

No que concerne ao argumento de que as decisões dos tribunais constituem a última palavra a respeito da solução para os conflitos e de que não há punição se a decisão destoar do que dispõem as fontes tradicionais do Direito, Hart realiza uma analogia que ajuda a entender a questão. Vejamos. Imaginemos um jogo. Se um grupo de pessoas vai jogá-lo, elas conseguem fazê-lo porque aplicam razoavelmente bem as regras de pontuação a casos particulares, estando normalmente de acordo. As disputas são poucas.

Suponhamos que decidamos alterar o jogo, introduzindo um árbitro. Nesse caso, o resultado do jogo será aquilo que o árbitro dirá que é (autoridade e definitividade). Entretanto, é seu dever aplicar as regras o melhor que puder. Existe um núcleo de significado das regras do qual o árbitro não pode se afastar. As afirmações dos jogadores são aplicações não-oficiais das regras de pontuação. Existe um risco de erro do árbitro, mas isso não pode se tornar muito frequente, pois nesse caso o jogo poderá se transformar em outro: o jogo da discricionaridade do árbitro. No jogo da discricionaridade do árbitro, aí sim, o resultado do jogo é o que o árbitro estabelecer que é, segundo sua discricionaridade. Aqui as decisões seriam sim, definitivas e infalíveis, e as afirmações dos jogadores seriam uma previsão daquilo que o árbitro decidiria.

Visto esse exemplo, fica fácil distinguir entre uma Constituição que estabeleça um sistema de tribunais, dispondo que o Direito será tudo aquilo que o Supremo Tribunal disser, e a Constituição de qualquer Estado moderno. Nesta última, as regras são suficientemente determinadas em sua parte central para fornecer padrões de decisão judicial correta. O desvio da regra, por parte dos juízes, é raro e, quando ocorre, é tido pela maioria como ilícito, sendo alvo de críticas.

A conclusão de Hart é a de que o formalismo e o realismo são exageros. Eles se corrigem mutuamente, residindo a verdade no meio deles. O teor em parte duvidoso das regras é elemento inerente a um sistema jurídico. E a escolha realizada pelos tribunais no âmbito da "textura aberta” acaba sendo aceita pela sociedade, que confere às decisões judiciais autoridade ex post facto, pelo êxito. Observe-se que o autor entende que não se trata de um simples processo de descoberta de uma solução que pode ser deduzida logicamente do sistema 
jurídico. Ele critica inclusive a ideia de Dworkin, segundo a qual o sistema jurídico nunca é incompleto, inconsistente ou indeterminado. Dworkin afirma que o juiz não realiza escolhas, já que o sistema jurídico também é integrado por princípios não formulados e que a resposta é dada pelos interesses superiores protegidos pelo ordenamento jurídico ${ }^{79}$. Hart se contrapôs a essa ideia, afirmando que, se não há como determinar objetivamente, em caso de casos difíceis, qual solução é a correta, então na verdade há discricionaridade.

Desse modo, nem o juiz cria todo o Direito que fundamenta sua decisão, nem decide apenas com base num processo de dedução e lógica. Há momentos de um e de outro, não se podendo negar que os tribunais realizam escolhas. Portanto, ora há necessidade da utilização de argumentos morais, ora pode-se utilizar os jurídicos apenas.

Schauer $^{80}$ observa que o Realismo Jurídico se coaduna mais com a análise das decisões das cortes supremas, onde há alta carga ideológica nos casos difíceis que são analisados. Nos casos comuns, afirma o autor, a visão tradicional de mera declaração da lei poderia explicar a maioria das decisões.

É certo que os juízes, assim como as demais pessoas, também “internalizaram” o Direito. Ao formular, pois, a decisão dita “intuitiva”, na verdade poderiam estar aplicando as normas que estão “internalizadas”. Essa questão será analisada mais detalhadamente no tópico que segue.

Não se pode negar que houve contribuições do Realismo Jurídico para a melhor compreensão da decisão judicial. Isso ocorreu ao revelar que há indeterminação significativa das regras; que nem todo o resultado interpretativo surge de um silogismo puro e que nem toda decisão judicial se embasa em argumentos jurídicos, de autoridade. O realismo também foi capaz de captar a perspectiva dos particulares em relação ao modo como o Direito poder ser descrito e explicado, além de revelar elementos para que os advogados melhor orientem seus clientes e argumentem perante os tribunais ${ }^{81}$. Ademais, essa corrente doutrinária possibilitou uma maior transparência das decisões judiciais,

\footnotetext{
${ }^{79}$ HART, Hebert. A teoria do direito norte-americana pelos olhos ingleses: o pesadelo e o nobre sonho. In Ensaios sobre Teoria do Direito e Filosofia. Coleção teoria e filosofia do direito. Ronaldo Porto Macedo, coord. São Paulo: Campus Jurídico, pp. 137-161.

${ }^{80}$ SCHAUER, Frederick. Thinking like a lawyer: a new introduction to legal reasoning. Londres: Harvard University Press, 2009.

${ }^{81}$ STRUCHINER, Noel e SHECAIRA, Fábio Perin. Verbete Realismo jurídico. Dicionário de teoria e filosofia do direito. Alexandre Travessoni, coordenador geral. São Paulo: LTr, 2011, pp. 348-351.
} 
quando, ao desconstruir o dogma interpretativo do positivismo ideológico e do formalismo, possibilitou que os juízes explicitassem os critérios extrajurídicos considerados na tomada de decisão.

\section{4 \\ Entendendo a Tomada de Decisão}

Vimos que as concepções de Estado de Direito induzem à defesa de uma ou outra prática decisória. As formais conduzem ao respeito das leis independente de seu conteúdo e as substantivas importam em decisões que dão prevalência a determinados direitos supralegais. Essas são questões normativas. Mas o que de fato acontece nos tribunais é uma questão descritiva. Diante do viés descritivo do realismo jurídico e do formalismo, optou-se por seguir a postura menos extremada de Hart. Compartilhando a compreensão desse autor de que, no processo de interpretação, o juiz ora simplesmente aplica as fontes tradicionais do direito, ora acaba por realizar escolhas, passa-se a analisar em que situações podemos imaginar haver certo grau de escolha e como ocorre o processo de decisão nos processos subjetivos, em que há partes e lide, especialmente na Justiça do Trabalho, caso referência escolhido.

A decisão envolve fatos, normas e solução do conflito. Esses elementos estabelecem uma relação e podem apresentar peculiaridades, que serão analisadas e discutidas adiante. Na tomada de decisão, entendemos que há uma circularidade, porque há necessidade, inicialmente, de se ter uma ideia dos fatos comprovados ou presumidos, para posteriormente buscar na legislação um regramento, ao passo que esse mesmo regramento é que é capaz de determinar quais são os aspectos fáticos relevantes e que deverão ser considerados para a solução do conflito.

Observe-se que a “decisão intuitiva” preconizada pelos realistas seria formulada sem a busca por um regramento. Para os realistas, essa busca seria posterior à decisão, decisão esta baseada em fatores extrajurídicos. Embora a circunstância narrada pelo Realismo possa ocorrer numa ou noutra situação, estando os padrões gerais de conduta internalizados no juiz, este poderia formular a decisão após o recurso a tais regras já aceitas. No Brasil, especialmente, o ensino nas faculdades de Direito e a seleção de juízes e dos cargos jurídicos públicos por meio de concurso público, em sua maioria, estimulam a observância e a aplicação 
das fontes formais de direito (incluindo os princípios constitucionais) em detrimento de questões extrajurídicas. Haveria, portanto, um “efeito sistêmico” de valorização da lei.

Assim, esse processo (circular) de tomada de decisão se confirma porque insere como elemento anterior à extração da solução o recurso ao ordenamento jurídico. Analisam-se os fatos relevantes, recorre-se às fontes normativas tradicionais, reavaliam-se os fatos e, então, extrai-se uma conclusão. Esse modelo não importa, porém, no reconhecimento de que a maior parte do processo decisório envolve apenas questões que se possam deduzir logicamente, sem o ingresso de razões de valor. Embora esteja calcado na lei, existem as tais possibilidades de escolha, as quais dificultam a utilização de uma argumentação jurídica estrita. Mais adiante, serão apresentadas algumas hipóteses em que é necessário haver uma escolha.

$\mathrm{Na}$ fase de definição dos fatos comprovados, busca-se extrair a verdade de acordo com normas procedimentais de produção da prova. Não adentraremos essa discussão, já que não é nosso objetivo estudá-la no presente. Por ora, basta partirmos da premissa de que há fatos comprovados ou presumidos. Visto isso, busca-se saber sobre que matéria trata a lide. Primeiro, se é de fato jurídica; se o Direito se importa com ela a ponto de regulá-la. Depois, se a lide é civil, criminal, trabalhista, consumerista, etc. Assim, podemos encontrar um dispositivo que trate da questão ou pode haver uma lacuna. Nesse último caso, a situação acaba tendo de ser ser resolvida por preceitos vagos e imprecisos, concernentes à semelhança da hipótese legal e da circunstância de fato. Pode haver, porém, um dispositivo (ou mais de um) que regule a questão. É o que será analisado a seguir.

\subsection{1}

\section{O Sentido e Alcance do Dispositivo Legal e a Determinação dos Fatos Relevantes}

Para estabelecer o sentido e o alcance do enunciado normativo, vale-se o jurista dos métodos de interpretação. Se o que se quer ressaltar é a certeza, a segurança e a previsibilidade, há que se dar preferência ao método literal ou gramatical. Entretanto, também é importante considerar o sistemático, porque esquecer que a ordem jurídica tem uma coerência interna significa, por via 
transversa, ferir a segurança e a previsibilidade que se quer proteger. Há outras normas igualmente válidas e eficazes.

Existem dispositivos cujo sentido e alcance são bastante fáceis de ser definidos. Veja-se, por exemplo, a proibição de dirigir a mais de $80 \mathrm{~km} / \mathrm{h}$ em determinada rodovia. Outros, porém, contêm termos cujo conceito é bastante indeterminado. Veja-se, por exemplo, a caracterização de empregado para fins de aplicação da Consolidação das Leis do Trabalho (CLT). Empregado é a pessoa física que presta serviços não eventuais, com subordinação, pessoalidade e onerosidade (artigos $2^{\circ}$ e $3^{\circ}$, CLT). O que seriam serviços “não eventuais”? Há muitas discussões cujo único propósito é apenas o de definir o sentido e alcance dessa expressão. O mesmo se pode dizer com relação à subordinação. Há grande discussão, tanto doutrinária quanto jurisprudencial, a respeito do significado desse termo. É certo que há situações claras de subordinação, mas outras há que se situam na zona de penumbra.

Note-se que há elevado grau de indeterminação até mesmo para se estabelecer quais são os fatos relevantes. Por exemplo: é relevante, para fins de caracterização da relação empregatícia, que haja metas de produção? Isso poderia influenciar no requisito subordinação ou até mesmo na caracterização da não eventualidade. O fato é que não são poucos os dispositivos com termos situados na "textura aberta” exposta por Hart. Ainda no Direito do Trabalho, temos o caso do cargo de confiança do art. 62, II, e do art. 224, § $2^{\circ}$, ambos da CLT, a expressão “tempo à disposição do empregador” (art. 4, CLT), a força maior (art. 501, CLT), dentre outros.

Como constatou Hart, com o passar do tempo e o aparecimento dos casos não pensados quando da edição da lei, a norma cada vez mais se torna determinada. Entretanto, nunca é possível abranger todos os casos nem saber de antemão quando aplicar a regra e quando não aplicá-la, porque o conceito ainda não está delimitado suficientemente (provavelmente nunca estará, porque a realidade é fluida; diversas são as situações novas que surgem a cada dia).

Note-se que não se trata de um problema de a norma abranger casos que não deveria ou de abranger menos situações do que poderia. A questão é anterior, situada na própria compreensão do texto legal e de quais fatos são relevantes. E 
não se está aqui querendo dizer, como os realistas, que a relevância é definida segundo considerações pessoais dos juízes. Isso traria, de fato, insegurança e instabilidade.

Desse modo, há de serem sopesadas razões e contra-razões, buscando-se o melhor argumento para enquadrar ou não o fato ao enunciado legal e para caracterizá-lo ou não como relevante. A argumentação envolve, necessariamente, questões substantivas.

\subsection{2}

\section{O Papel dos Princípios na Atividade de Interpretação}

A definição do melhor argumento acaba por envolver uma escolha do julgador. Essa escolha não pode ser, porém, arbitrária, embora envolva graus de discricionariedade, dependendo do caso. Se essa escolha estiver em consonância com os valores constitucionais, traduzidos em princípios, há que se reconhecer que a decisão se reporta ao Direito. Ora, o princípio, como estado de coisas a ser buscado, podem representar uma fonte de argumentos consequencialistas ou deontológicos prevista no próprio ordenamento jurídico. Entretanto, mesmo nesse caso, de definição do alcance e do sentido do princípio e de qual prevalecerá, há diferentes possibilidades de escolha.

Quando o enunciado contém termo cujo conceito é em grande parte indeterminado, é importante que se invoque a teleologia ou a finalidade da norma. Isso foi vislumbrado por Hart ao referir que, na incidência do enunciado normativo, observa-se se o caso presente se assemelha suficientemente ao caso descrito (ou exemplo), em aspectos relevantes, de acordo com a finalidade da regra $^{82}$. O autor indica que quanto maior o número de casos incertos resolvidos, mais se individua a finalidade da proposição jurídica. Vejamos o que ele diz:

O poder discricionário que assim lhe é deixado pela linguagem pode ser muito amplo; de tal forma que, se ela aplicar a regra, a conclusão constitui na verdade uma escolha, ainda que possa não ser arbitrária ou irracional. A pessoa opta por acrescentar a uma série de casos um caso novo, por causa das semelhanças que podem razoavelmente ser consideradas, quer como juridicamente relevantes, quer como suficientemente próximas. No caso das regras jurídicas, os critérios de relevância e de proximidade da semelhança dependem de factores muito complexos que atravessam o sistema jurídico e das finalidades ou intenção que possam ser atribuídos à regra.

\footnotetext{
${ }^{82}$ op. cit. p. 140.
} 
Nesse sentido, para compreensão da regra, são necessárias considerações de substância, valorativas. Além disso, o ordenamento jurídico tem uma coerência interna. É certo que há valores e princípios conflitantes, mas a relação que estabelecem entre si é de mútua restrição e de imbricamento, de modo que nenhum deles seja completamente excluído do sistema. Assim, os princípios podem dar coerência ao ordenamento, garantindo que a interpretação não seja segmentada.

Nessa esteira, Canaris ressaltou a importância da teleologia na formulação do conceito de sistema jurídico, identificando que a unidade interna e a adequação valorativa da ordem jurídica são conferidas pelos princípios ${ }^{83}$, não pelas regras, conceitos, institutos ou valores. Isso porque são os princípios que congregam os valores fundamentais mais profundos, valores estes que se libertam do seu isolamento aparente e se reconduzem à conexão “orgânica”, chegando ao grau de generalização sobre o qual a unidade do sistema se torna perceptível ${ }^{84}$.

Adotando-se essa perspectiva, excluir os princípios do conceito de Direito significaria negar a coerência interna do ordenamento jurídico. Além disso, como visto, os princípios podem ter função informativa, de possibilitar a definição do alcance e sentido das regras, especialmente em caso de termos com baixo grau de determinação.

\subsection{3 \\ O Conflito entre Normas Jurídicas Igualmente Aplicáveis}

Visto que os dispositivos podem não ser suficientemente determinados e que os princípios podem ter a função de contribuir para torná-los mais determinados,

\footnotetext{
${ }^{83}$ Humberto Ávila distingue as regras dos princípios da seguinte forma: “Os princípios são normas imediatamente finalísticas, primariamente prospectivas e com pretensão de complementariedade e de parcialidade, para cuja aplicação se demanda uma avaliação da correlação entre o estado de coisas a ser promovido e os efeitos decorrentes da conduta havida como necessária à sua promoção." "As regras são normas imediatamente descritivas, primariamente retrospectivas e com pretensão de decidibilidade e abrangência, para cuja aplicação se exige a avaliação da correspondência, sempre centrada na finalidade que lhes dá suporte ou nos princípios que lhes são axiologicamente sobrejacentes, entre a construção conceitual da descrição normativa e a construção conceitual dos fatos." ÁVILA, Humberto. Teoria dos Princípios: da Definição à Aplicação dos Princípios Jurídicos. $8^{\mathrm{a}}$ ed. São Paulo: Malheiros Editores: 2008, pp.78-79.

${ }^{84}$ CANARIS, Claus Wilhem. Pensamento Sistemático e Conceito de Sistema na Ciência do Direito. Tradução de Antônio Menezes Cordeiro. Lisboa: Fundação Calouste Gulbenkian, 1989, pp. 71 e ss.
} 
além de, por outro lado, garantir a coerência do ordenamento jurídico, observamos que também existem casos de conflito de normas em que pode haver necessidade de escolha. Tomando-se o termo dispositivo como o objeto da interpretação (texto) e a norma como o resultado da atividade interpretativa ${ }^{85}$, observa-se que há dispositivos a partir dos quais é possível construir mais de uma norma, que às vezes incide em mais de uma situação concreta. Também há dispositivos aptos a gerar normas com sentidos distintos, dependendo da interpretação que se lhes dá.

Veja-se, por exemplo, a técnica da interpretação conforme a Constituição (art. 28, Lei 9.868/99), que consiste em excluir uma ou mais possibilidades interpretativas, com afirmação de uma outra que deverá prevalecer por estar em consonância com a Constituição. Constrói-se mais de uma "norma” a partir do mesmo dispositivo, entendendo-se como válida apenas uma delas.

Pode-se citar também a técnica da declaração de inconstitucionalidade parcial sem redução de texto, que diz respeito à decisão que considera inválida a incidência do dispositivo sobre uma determinada situação, permanecendo válida para outras hipóteses. Há, pois, mais de uma norma consoante se considere uma ou outra situação de fato. Aplicada a uma determinada situação, porém, há violação à Constituição. Frise-se que a norma não é extraída somente em tese, ou seja, afastando as peculiaridades concretas que se apresentam ao leitor do texto legal. A interpretação também considera, muitas vezes, essas peculiaridades (os fatos relevantes).

Humberto Ávila também faz referência ao caráter pluridimensional dos enunciados normativos, por sua capacidade de germinar, por meio da atividade do intérprete, uma regra e um princípio concomitantemente. No primeiro caso, o aplicador privilegia o aspecto comportamental. No segundo, o valorativo, autonomizando-o para alcançar comportamentos inseridos noutros contextos ${ }^{86}$. Diante disso, o art. 462, CLT, que descreve a conduta de desconto salarial, proibindo-a a não ser nas situações que enumera, pode ser entendido como regra (se observado do ponto de vista de descrição de uma conduta proibida) ou como princípio (se autonomizado para se compreendê-lo como princípio da intangibilidade salarial).

\footnotetext{
${ }^{85}$ ÁVILA, Humberto. Op. cit., pp. 30/34.

${ }^{86}$ Op. cit., pp. 69/70.
} 
Partindo-se, pois, da premissa de que os dispositivos podem gerar mais de uma norma, as quais podem se revestir da natureza de princípio ou regra, passamos a analisar a antinomia ou conflito entre normas. Tradicionalmente discorre-se a respeito do parâmetro para resolução do conflito entre regras denominado hierárquico, ao lado do cronológico e de especialidade ${ }^{87}$. Isso significa que, se o choque ocorre entre uma regra constitucional e outra com status de lei ordinária, prevalece a primeira. Se em conflito uma regra anteriormente editada com outra posteriormente aprovada, prevalece esta última, sendo inválida a primeira. Se uma mais especial com uma mais genérica, aplica-se aquela em detrimento desta. Assim, o entendimento normalmente encontrado na doutrina é de que a antinomia se apresenta de forma abstrata, necessária e situada no plano da validade ${ }^{88}$ (com exceção do critério da especialidade, em que ambas as regras - a geral e a especial - continuam válidas).

No que tange à interpretação dos princípios, encontra-se bastante difundida e aceita a idéia de ponderação. Isso porque, em razão do caráter mais vago desses e do recorrente conflito nas situações concretas postas em juízo, os critérios cronológico, de especialidade e hierárquico normalmente não resolvem a antinomia. Assim, ponderam-se os princípios para dar prevalência a um em detrimento de outro ou para garantir a aplicação de ambos, na busca de um ponto ótimo de efetivação. Observe-se que a ponderação, nesse sentido, nada mais é que a adução de razões de substância a favor ou contra os princípios em cotejo. Nesse sentido, há necessidade de utilização de argumentos consequencialistas ou deontológicos e, muitas vezes, do recurso a uma teoria moral. Dworkin e Alexy informam que a antinomia no caso dos princípios se apresenta de forma concreta (aparece em situações concretas), contingente (pode ou não ocorrer) e situada no plano da eficácia (pois nenhum dos princípios deixa de ser válido) ${ }^{89}$.

Entretanto, também há casos em que ambas as regras são existentes, válidas e igualmente aplicáveis, embora conflitantes, e que os critérios tradicionais não resolvem a antinomia. Assim, procede-se ao sopesamento de razões e contra-

\footnotetext{
${ }^{87}$ BOBBIO, Norberto. Teoria do Ordenamento Jurídico. Tradução Maria Celeste C. J. Santos; rev. téc. Claudio De Cicco; apres. Tércio Sampaio Ferraz Júnior. 10ª ed. Brasília: Editora Universidade de Brasília, 1997, p. 91-97.

${ }^{88}$ ÁVILA, Humberto. Op. cit. p. 87. O autor faz referência à distinção forte entre princípios e regras realizada por Dworkin e Alexy.

${ }^{89}$ Idem, p. 87.
} 
razões que, por vezes, afasta uma regra para dar prevalência a outra ou para fazer incidir um princípio ${ }^{90}$. Aplicar simplesmente uma das regras a um determinado caso e afirmar que é a única conclusão possível pode violar a segurança e previsibilidade, porque se está desconsiderando (e afastando da argumentação) outro enunciado normativo tão aplicável quanto o primeiro.

Como se pode perceber, pondera-se uma regra com a outra de modo a encontrar a solução harmoniosa, que normalmente consiste em afastar uma delas para aplicar a outra. Ou, diante de alternativas interpretativas (mais de uma norma), há ponderação de razões e contra-razões para a escolha de qual prevalecerá. Não há utilização, nesses casos, dos critérios hierárquico, cronológico e de especialidade, mas sim de argumentos consequencialistas ou deontológicos.

Conforme defende Humberto Ávila, a ponderação não é método privativo de aplicação dos princípios nem estes possuem uma dimensão de peso. O sopesamento de razões e contra-razões que culmina com a decisão interpretativa também pode estar presente no caso das regras. Por outro lado, a dimensão axiológica não é privativa dos princípios, mas elemento integrante de qualquer norma jurídica.

Essa atitude interpretativa não desrespeita as escolhas do Poder Legislativo, pois ambas as regras em conflito são de observância obrigatória, havendo necessidade de compatibilizar previsões legais e constitucionais. Ora, também quando se recorre à analogia se está aplicando uma regra para um comportamento diverso (mas semelhante) daquele que ela descreve e isso por aplicação do ordenamento jurídico sistematicamente.

Constata-se que a atividade do juiz é mais ativa do que se normalmente se admite, ao menos na Justiça do Trabalho. Assim, a ponderação pode ser utilizada tanto quando se tem em cotejo duas ou mais regras e dois ou mais princípios. Não há, no seu manejo, ausência de legitimação democrática, pois é uma necessidade da organicidade do ordenamento jurídico e do constitucionalismo, em que pese haja divergência a respeito do grau desejável de utilização de princípios. Observe-

\footnotetext{
${ }^{90}$ Além do método sistemático, o mesmo autor também discorre a respeito do processo lógico (que se subdivide em lógico propriamente dito e sociológico) e gramatical ou filológico. Já Caio Mário da Silva Pereira fala a respeito do elemento gramatical ou literal, lógico ou racional, sistemático e histórico (PEREIRA, Caio Mário da Silva. Instituições de Direito Civil. 19a ed. Vol. I. Rio de Janeiro: Editora Forense, 1998, pp. 127/130).
} 
se que o choque entre uma regra e um princípio pode estar ligado à discussão a respeito da sobreinclusão e subinclusão, que será analisada posteriormente.

\subsection{4}

\section{Ainda no Conflito de Normas: Quando a Parte de um Processo Agrega Razões de Substância}

Pode ocorrer, ainda, de, aferidos os fatos comprovados ou presumidos, bem como a regra aplicável (que é clara e cujos conceitos são determinados), haver outro tipo de necessidade de argumentação substantiva, valorativa. Isso ocorre quando, por exemplo, uma das partes alega a inconstitucionalidade da regra que iria ser aplicada com base em determinado princípio constitucional. Ora, o juiz não pode deixar de analisar a alegação, visto que no ordenamento jurídico brasileiro o controle de constitucionalidade é exercido, também, de forma difusa. Além disso, se de fato ocorrer inconstitucionalidade, a questão é de aplicação de uma norma superior (Constitucional) em detrimento de uma inferior (lei). As razões de substância têm, pois, de ser enfrentadas, mesmo sendo o enunciado claro o bastante e mesmo que seja para dizer que, em razão da segurança, certeza e previsibilidade, prevalece a regra.

Veja-se, ilustrativamente, a questão da obrigatoriedade de prévia submissão das demandas trabalhistas ao crivo da comissão de conciliação prévia (art. 625-D, CLT). Praticamente toda reclamação trabalhista, na petição inicial, vinha alegando inconstitucionalidade do dispositivo, por ferir a inafastabilidade do controle judicial (art. 50, XXXV, CRFB/88). Seria mesmo razoável que um meio alternativo de solução de conflitos, como as comissões de conciliação prévia, tivesse de ser obrigatório porque o dispositivo é formado pela locução verbal “será submetida”? Era o que se questionava. De toda sorte, o juiz tinha de realizar análise de substância, até a questão ser delineada pelo Supremo Tribunal Federal, que concedeu medida cautelar ao art. 625-D, parágrafo único, CLT, para dar interpretação conforme a constituição, estabelecendo a faculdade de submissão (informativo 546 do STF) ${ }^{91}$.

Concluindo, a decisão da forma de solucionar um conflito posto em juízo é uma questão que não se restringe às preferências pessoais do juiz, mas que está

\footnotetext{
${ }^{91}$ Disponível em <http://www.stf.jus.br/arquivo/informativo/documento/informativo546.htm>. Acessado em 07.03.2014.
} 
relacionada ao funcionamento de um sistema, tanto no seu aspecto educativo (quando se pensa nas faculdades de Direito) quanto na sua dimensão seletiva (que diz respeito ao formato das provas de concurso e da seleção de juízes). Além disso, o processo decisório, embora envolva respeito à lei, não parte da regra para, depois, analisar o caso concreto. Parte-se, antes, dos fatos comprovados ou presumidos, para depois se analisar as fontes tradicionais do Direito, reavaliar os fatos (definindo quais são relevantes) e, então (sopesando-se muitas vezes razões e contra-razões), extrair a conclusão.

Assim, permanece a questão: no momento de envidar essa forma de decidir circular (fatos - lei - fatos), prevalecem apenas os argumentos jurídicos ou de autoridade ou são necessárias análises morais, de substância? Em outras palavras, dos casos submetidos ao judiciário, seriam realmente maioria os casos claros? Essa é uma questão que, como disseram os realistas, só a pesquisa empírica poderá revelar. Entretanto, diante das ponderações apresentadas, nota-se que são muitas as situações em que as razões de substância têm que ser analisadas. Não é possível uma simples subsunção sem o ingresso de dados valorativos: para resolver um problema de lacuna; para a própria compreensão do enunciado legal quando há conceitos com grau pequeno de determinação; para definição dos fatos relevantes; para, no conflito entre regras, escolher qual deve ser aplicada, garantindo a coerência do sistema jurídico; para resolver conflitos entre princípios em caso de inexistir regra clara; para dar uma resposta à parte que traz um argumento de substância.

Desse modo, o contexto em que são proferidas as decisões pelos magistrados trabalhistas fluminenses é marcado por muitas situações em que há necessidade de utilização de argumentos morais. Para seguir à análise da questão inicialmente proposta, que diz respeito à visão dos juízes a respeito da prevalência do justo ou do legal em casos em que não há necessidade de utilização de razões de substância, mas em que é possível tal utilização, é preciso fixar alguns conceitos, que serão estudados no próximo tópico.

\section{5}

\section{Subinclusão e Sobreinclusão}

Essa questão está atrelada às ideias de subinclusão e sobreinclusão, que decorrem da característica da generalidade das leis. Por genéricas, tem-se não 
apenas que as leis são aplicáveis a todos os integrantes de um tipo, mas também que nem sempre obstam o mal que se quer evitar ou garantem o bem que se quer alcançar $^{92}$. Para esclarecer, veja-se que é comum que a criação de uma regra prescritiva decorra da observação de um caso particular, que é tomado como exemplo de uma situação que se quer evitar ou de uma meta que se quer alcançar. Assim, escolhem-se os dados relevantes do exemplo para formular a regra, sendo necessário que esses dados tenham um nexo causal probabilístico relevante com a finalidade que se persegue.

Pode-se citar como exemplo a regra que impõe, no Direito do Trabalho, a jornada máxima de oito horas. Historicamente, ela decorreu da situação em que, dada a abundância de mão de obra e ausência de postos de trabalho suficientes para abarcá-la, os trabalhadores aceitavam submeter-se a jornadas extenuantes, para não perder o emprego. O empregador estava em posição de impor as regras e o empregado não tinha muita opção, senão aceitá-las, para sua própria sobrevivência. Considerando-se a extrema situação de desigualdade de forças que caracteriza esse tipo de relação, tomou-se esse caso de exploração da mão de obra como algo que se quer evitar, estabelecendo-se uma jornada de trabalho máxima que, no caso brasileiro, em regra geral, é de oito horas (art. $7^{\circ}$, XIII, CRFB/88), na ideia de que oito horas são destinadas ao repouso e as outras oito às atividades pessoais.

Entretanto, isso não significa que a limitação da jornada é suficiente para satisfazer a justificação subjacente à regra: vedação de exploração extenuante do trabalho. Muitas vezes se vê esse tipo de situação em um lapso temporal de oito horas (e até menos) e, por outro lado, atividades bastante tranquilas em jornada de dez horas. Como dito, é somente provável que uma jornada de mais de oito horas seja exploratória, mas isso não é necessariamente verdadeiro para todos os casos. Nesse ponto é que se dá a situação de sobreinclusão e subinclusão, quando, da aplicação da regra, não se obsta o mal que se pretende evitar ou não se garante o bem que se quer alcançar.

\footnotetext{
${ }^{92}$ SCHAUER, Frederick. Playing by the rules: a philosopical examination of rule-based decision-making in law and in life. Oxford: Clarendon Press, 2002, pp. 31-34. A esse respeito, ver também STRUCHINER, Noel. O direito como um campo de escolhas: por uma leitura das regras prescritivas como relações. In Nas fronteiras do formalismo: a função social da dogmática jurídica hoje. RODRIGUES, José Rodrigo; DA SILVA E COSTA, Carlos Eduardo Batalha e BARBOSA, Samuel Rodrigues, organizadores. Rio de Janeiro: Editora Saraiva, 2009, p. 109.
} 
Podemos exemplificar essa questão com o caso dos empregados domésticos. Recentemente, com a aprovação da Emenda Constitucional 72/2013, eles também passaram a estar protegidos com a jornada máxima de oito horas. Isso decorreu do caso exemplar que se quer evitar de exploração de sua força de trabalho, por jornadas extenuantes, realizadas por algumas famílias. Mas pense-se, por exemplo, na seguinte situação: uma empregada doméstica contratada apenas para fazer companhia, no período noturno, à Sra. Maria, uma pessoa idosa, que já sofreu um enfarto e, por isso, não pode ficar sozinha. A Sra. Maria faz sua própria comida e tem autonomia para caminhar, realizar sua higiene pessoal e para dormir. Entretanto, o risco de passar mal exige que possua uma acompanhante. Essa acompanhante passa a maior parte do tempo dormindo no trabalho. Entretanto, permanece cerca de dez horas na residência da Sra. Maria.

Pela aplicação da regra de que deve ser observada a jornada de oito horas, acaba sendo ilícita a exigência de trabalho na nona e décima horas. A sanção prevista é de pagamento dessas horas como extraordinárias, com reflexos nas demais parcelas contratuais, como décimo terceiro salário e férias. Como se vê, no caso da Sra. Maria, a limitação legal da jornada - oito horas - não evita o mal de exploração da mão de obra por jornadas extenuantes. O trabalho da acompanhante não é extenuante no caso narrado.

Visto o exemplo, tem-se que a sobreinclusão ocorre quando a regra alcança casos particulares que não geram a consequência que representa a justificação da regra. $^{93}$ Não há exploração de mão de obra pela Sra. Maria e, mesmo assim, a regra estabelece que ela não pode exigir mais do que oito horas de trabalho de sua acompanhante. Já a subinclusão diz respeito à situação em que a regra não engloba situações que deveria para atingir a justificação que lhe é subjacente ${ }^{94}$. Há operadores de telemarketing, por exemplo, que trabalham apenas seis horas, mas têm que atingir metas irrealizáveis nesse lapso temporal, o que faz com que o trabalho seja bastante extenuante.

Observe-se que, mesmo com essas dificuldades, a generalização é necessária para a comunicação e para a pretensão de influenciar comportamentos.

\footnotetext{
${ }^{93}$ SCHAUER, Frederick. Playing by the rules: a philosopical examination of rule-based decision-making in law and in life. Oxford: Clarendon Press, 2002, pp. 31-33.

${ }^{94}$ Idem, pp. 31-33.
} 
Seria inexequível a tarefa de tentar regrar todos os casos possíveis, com todas as exceções e contingências existentes ${ }^{95}$. Como, então, lidar com essa característica inerente a qualquer regra? Que decisão tomar diante de uma experiência recalcitrante, que ocorre justamente quando aparece um caso que foge à estatística, situando-se fora do nexo causal probabilístico?

A postura formalista opta pela aplicação da regra. ${ }^{96}$ Segundo ela, não se pode levar em consideração fatores externos aos previstos no enunciado normativo. Quando da incidência da lei se extrai um resultado claro, o responsável pela decisão se vincula a esse resultado e a nenhum outro. Observe-se que, nesse ponto, existem dois conceitos distintos de formalismo. O defendido por Schauer e Struchiner é distinto daquele descrito anteriormente e criticado por Hart. Isso porque não considera o Direito como um sistema completo e preciso. Ele admite que há possibilidades de escolha, como ressaltou Hart, afirmando apenas que, nos pontos em que o Direito é determinado, deve-se optar por sua aplicação, mesmo que o resultado seja subótimo.

A postura particularista ou conversacional ${ }^{97}$, ao reconhecer a existência da sobreinclusão e da subinclusão, defende que as decisões devem se pautar pela busca do melhor resultado possível para cada caso que possa aparecer, de acordo com a justificação da regra ou com outras razões pertinentes. Devem ser consideradas todas as circunstâncias do caso para se realizar o cálculo decisório, sendo as regras apenas sugestões.

Esses modelos são extremos. Há modelos intermediários, como o particularismo sensível às regras e o positivismo presumido ${ }^{98}$. Deixando de lado as razões espúrias ou arbitrárias, os dois modelos anteriores expressam os extremos do que pode ser considerado legítimo segundo uma ou outra concepção de Estado de Direito, e o objetivo é analisar para qual desses extremos pendem as decisões judiciais. Observe-se que a opção pelo formalismo jurídico não nega que a aplicação da literalidade da lei gera, em determinadas ocasiões, resultados

\footnotetext{
${ }^{95}$ STRUCHINER, Noel. O direito como um campo de escolhas: por uma leitura das regras prescritivas como relações. In Nas fronteiras do formalismo: a função social da dogmática jurídica hoje. RODRIGUES, José Rodrigo; DA SILVA E COSTA, Carlos Eduardo Batalha e BARBOSA, Samuel Rodrigues, organizadores. Rio de Janeiro: Editora Saraiva, 2009, p. 110.

${ }^{96}$ Idem, p. 116.

${ }^{97}$ Ibidem, p. 115.

${ }^{98}$ Ibidem, pp. 120-125.
} 
subótimos, mas parte da consideração de que o modelo particularista pode gerar mais erros que acertos.

Do ponto de vista normativo, uma forma de se compreender o debate formalismo versus particularismo envolve a alocação de $\operatorname{poder}^{99}$. Se, em determinado contexto, uma sociedade confia amplamente nos juízes das cortes superiores, então o modelo particularista se apresentaria como o mais adequado, porque aloca mais poder no Judiciário, confiando que os erros decisórios serão poucos e que, na maior parte, os resultados serão melhores. Se essa confiança, entretanto, não existe, o modelo formalista se apresentaria como o mais pertinente, por entrincheirar as regras, alocando mais poder nos órgãos de produção legislativa.

Um outro argumento diz respeito àquele de que não se trata de uma decisão contextual sobre qual modelo é o melhor, mas sim de uma decisão moral ou política: o formalismo jurídico aloca poder naqueles que estão legitimados a decidir, porque eleitos: os integrantes do Poder Legislativo. ${ }^{100}$ Assim, os responsáveis pela decisão deveriam reconhecer a autoridade das regras mesmo quando sua aplicação não realiza a justificação que gerou a sua criação.

O debate normativo envolve, como já mencionado, bons argumentos para a defesa de um ou outro modelo. Como se pode perceber, existem duas perspectivas distintas para análise da questão da sobreinclusão e subinclusão: uma partindo do cidadão para o Judiciário, que tem como base o conceito de Estado de Direito e busca aferir se as decisões - formalistas ou particularistas - são consideradas legítimas do ponto de vista do jurisdicionado. Essa perspectiva foi estudada no primeiro capítulo, havendo ainda uma análise empírica a ser descrita a seguir. A outra perspectiva ou ótica, investigada neste e no próximo capítulo, é aquela que parte dos juízes para a sociedade, da prática decisória dos magistrados, e, nesse ponto, importante aferir se ela tende para o formalismo ou para o particularismo. Como a relevância do conceito de Estado de Direito decorre de sua função legitimante dos governos, a legitimidade é importante sob a visão do cidadão comum, não da autoridade que decide.

\footnotetext{
${ }^{99}$ Ibidem.

${ }^{100}$ Ibidem.
} 


\section{O Legal e o Justo}

\section{1}

\section{O Estado de Direito sob a Perspectiva do Jurisdicionado: uma Análise Empírica}

$\mathrm{Na}$ introdução ao presente estudo, foi informada a existência de uma pesquisa em que os cidadãos consideraram mais apropriada a justiça do resultado quando em conflito com a aplicação estrita da norma jurídica. Nessa seção, ressaltamos a existência de outros experimentos ${ }^{\mathbf{1 0 1}}$ que procuraram compreender as reações individuais à violação da regra por uma determinada autoridade, buscando acessar qual concepção de Estado de Direito é invocada ${ }^{102}$.

O objetivo dos experimentos era responder à seguinte questão: se determinadas leis produzem resultados injustos que não são consistentes com valores morais universais (por exemplo, com a justiça), são essas leis legítimas? pergunta essa normalmente levantada pelos defensores de uma concepção substantiva do Estado de Direito.

Para os fins dos experimentos, são considerados participantes aqueles que respondem às perguntas objeto da pesquisa; agentes as autoridades descritas nas estórias narradas nas vinhetas que optam por violar ou não determinada regra para garantir um determinado resultado desejado; e, por fim, considera-se cenário o pano de fundo da estória, o local em que ela se passa.

No primeiro experimento analisado, foi solicitada a opinião dos participantes a respeito da atitude de um professor que, segundo a estória que lhes foi entregue, violava o procedimento estabelecido - de que as provas não podiam ser identificadas - para atingir um resultado desejado. Utilizou-se um caso comum e cotidiano, que não adentrava discussões políticas: de um professor que alterava a nota final de dois alunos. Assim, foi indagado aos participantes, duzentos e quarenta e sete estudantes dos Estados Unidos, com média de 18,9

\footnotetext{
${ }^{101}$ SCHWEITZER, N. J.; SYLVESTER, Douglas J. e SAKS, Michael J. Rule violations and the rule of law: a factorial survey of public attitudes. Disponível em $<$ http://papers.ssrn.com/sol3/papers.cfm?abstract id=951005 $>$. Acessado em 28.02.2013. SCHWEITZER, N. J.; SAKS, Michael J. e LOVIS-MCMAHON, David. Is the rule of law a law of rules? Judgments of rule of law violations. Disponível em $<$ http://papers.ssrn.com/sol3/papers.cfm?abstract id=1439055 > . Acessado em 28.02.2013.

${ }^{102}$ Is the rule of law a law of rules? Judgments of rule of law violations. Disponível em $<$ http://papers.ssrn.com/sol3/papers.cfm?abstract_id=1439055>. Acessado em 28.02.2013.
} 
anos, se julgavam apropriada a atitude do professor.

Estabeleceram-se três variações. A primeira era referente à força da norma. Assim, para alguns participantes foi dito que a regra de que as provas não podem ser identificadas era apenas uma recomendação; para outros que se tratava de uma imposição. A segunda variação foi concernente à intenção do agente, se boa ou ruim. Desse modo, em alguns casos o professor não gostava do aluno e queria, arbitrariamente, diminuir sua nota, além de aumentar a nota de outro estudante, de quem gostava; em outros, o professor tinha dado a dois alunos o guia de estudos errado, razão pela qual queria identificar as provas dos estudantes para ajustar suas notas, a fim de corrigir o erro. A terceira variação foi aquela que disse respeito à decisão adotada, se de respeitar a norma e não identificar a prova ou de violá-la e descobrir de quem eram os exames.

Concluiu-se que não houve diferença significativa nas respostas quanto ao fato de se tratar de uma recomendação ou de uma imposição. Além disso, os participantes, ao julgar a atitude do professor, deram mais atenção ao resultado justo que à violação da regra. Esse resultado corroborou o de um experimento anterior referido pelos autores, o qual teve como participantes cidadãos de todo o país. O mais surpreendente, segundo a pesquisa anterior, foi o quão pouco peso foi dado para a violação da regra. A variação atribuída à questão da regra foi de menos de $1 \%$ do total de variação nas respostas, enquanto que o resultado justo ou injusto foi responsável por 35\% do total da variação. Essa pesquisa também foi realizada tendo como participantes advogados dos Estados Unidos e, embora a variação referente à observância ou não da regra tenha subido para $6 \%$ do total, ainda sim a questão da justiça do resultado foi responsável pela maior parte da variação (36\%).

No experimento ora analisado, a observância das regras foi considerada desejável quando elas produziam um resultado justo. Mas quando surgia uma consequência injusta a partir da aplicação da regra, os participantes prestaram pouca atenção à norma. Quando a intenção era ruim, a decisão mais apropriada, segundo os participantes, era de obediência à norma. Quando boa, ou seja, para produzir um bom resultado, a decisão mais apropriada era, segundo eles, de desobedecer à norma. Não foi pesquisada a situação de a intenção ser boa e produzir um resultado ruim ou de a intenção ser ruim e produzir um resultado 
justo.

Desse modo, concluiu-se que, para produzir um resultado justo, a desobediência à lei foi aceita e considerada recomendável. As conclusões sugerem que o resultado bom é determinante no julgamento moral, alinhando-se com uma visão substantiva do Estado de Direito.

No segundo experimento, considerando-se que não houve efeitos significativos na circunstância de se tratar de uma recomendação ou de uma regra impositiva, essa variante foi omitida, assim como o foi a variante da intenção ruim, já que neste último caso a resposta foi universal no sentido de que a regra não poderia ser violada. Examinaram-se, portanto, situações em que as regras e os resultados estavam em conflito direto - quando a observância de uma regra estabelecida produzia uma injustiça, enquanto que a violação à norma culminava num resultado justo.

O estudo procurou discernir três cenários: de uma corte criminal, de uma escola e de um jogo de basebol. Assim, em parte das vinhetas a posição da autoridade era ocupada por um juiz, noutra parte por um professor e, nas demais, por um árbitro do jogo. Os elementos por trás dos cenários são os mesmos: uma autoridade viola uma norma para obter um resultado justo. Os participantes eram duzentos e seis estudantes dos Estados Unidos de, em média, 19,57 anos.

No primeiro cenário, de uma corte criminal, o juiz excluía ilicitamente uma informação para garantir que a decisão do júri fosse justa. No caso descrito, a polícia enviara elementos para análise de DNA para o laboratório errado e essa prova, que deveria ser excluída pelo juiz, inocentaria o réu. Entendeu-se que era apropriado que o juiz desconsiderasse ou superasse a regra que mandava excluir a prova, para garantir um veredito justo.

No segundo cenário, dois estudantes recebiam da secretária um guia de estudos pra prova errado e, em razão disso, o professor violava a regra de que as provas não podiam ser identificadas e ajustava as notas, aumentando-as. Os participantes consideraram apropriada a atitude do professor que violava a regra da escola para assegurar que os estudantes recebessem uma nota justa. Mas também consideraram apropriada a decisão de não violar a regra de proibição de identificação das provas, do que se deduz que, de um ou de outro modo, o 
professor, segundo os participantes, estava agindo justificadamente.

No terceiro, que falava de um árbitro que violava uma regra para garantir que o jogo fosse justo, o resultado foi distinto: houve clara opção pela regra do jogo, mesmo que isso levasse determinado time a sofrer alguma injustiça.

Desse modo, com exceção do jogo de basebol, os estudos permitiram concluir que, quando a intenção é ruim do ponto de vista moral do participante, em geral entende-se que o mais acertado é obedecer à lei. A desobediência só vem como recomendável ou aceitável quando a observância da norma gera um resultado injusto. A distinção entre regra (impositiva) ou recomendação se mostrou irrelevante na experiência com os estudantes.

Pendendo para uma concepção substantiva de Estado de Direito, a pesquisa indica que a maioria dos cidadãos considera legítima a decisão judicial que, para garantir a justiça do resultado, deixa de aplicar uma regra. Vejamos se, na Justiça do Trabalho da Primeira Região, os julgados também compartilham esse tipo de resposta às situações de sobreinclusão e subinclusão.

\section{2 \\ O Estado de Direito e a Prática Decisória: análise empírica do caso referência Primeira Instância do Tribunal Regional do Trabalho da Primeira Região}

Se sob a ótica do cidadão comum (no caso, estudantes e advogados) há legitimidade em uma decisão que supera a regra para garantir um resultado justo, fizemos uma análise de decisões judiciais que parecia informar que o Judiciário Trabalhista pende para o formalismo, em casos de sobreinclusão e subinclusão. Para chegar a esse indício, realizou-se um estudo de acórdãos proferidos no âmbito do Tribunal Regional do Trabalho da Primeira Região, por meio de sua biblioteca digital $^{103}$.

Eis alguns exemplos. $\mathrm{O}$ primeiro diz respeito à multa incidente quando 0 empregador dispensa o empregado sem justa causa e não paga (ou não ajuíza ação

\footnotetext{
${ }^{103}$ A esse respeito, ver PEIXOTO, Helen Marques. Sobreinclusão e Subinclusão no Judiciário. In Justiça, Direito e Ética Aplicada. VI Simpósio Internacional sobre a Justiça. Agemir Bavaresco, Nythamar de Oliveira e Paulo Roberto Konzen (organizadores). Porto Alegre: Editora Fi, 2013, pp. $140-162$. Disponível

$<$ http://webcache.googleusercontent.com/search?q=cache:nxREIs9eF9AJ:gttj.files.wordpress.com/ 2013/08/helen-marques-peixoto-artigo_versc3a3o_final.doc $+\& c d=1 \&$ hl=pt-BR\&ct=clnk\&gl=br $>$. Acessado em 25.01.2014.
} 
de consignação em pagamento) no prazo fixado pelo art. 477, § $6^{\circ}$, CLT. Em um dos julgados, ficou registrado que

“Não parece razoável impor a multa do artigo 477 da CLT à empresa já que, apesar de não ter consignado os valores, expediu vários telegramas ao autor, tentando entrar em contato com este inclusive para o pagamento das verbas rescisórias. Não me parece justo que se exija da empresa tal postura diante de empregado comprovadamente relapso que, frise-se, não só abandonou o emprego após curto contrato, como sequer compareceu à audiência de prosseguimento e, finalmente, tampouco apresentou contrarrazões ao apelo do réu.,"104

A maioria dos julgados, porém, aplicava a multa independente das circunstâncias do caso concreto, bastando que estivessem presentes os elementos descritos no dispositivo legal que prevê a incidência da penalidade (art. 477, § $8^{\circ}$, CLT ${ }^{105}$. Dos seis analisados, cinco decidiram nesse sentido. Ilustrativamente:

“MULTA DO $\S 8^{\circ}$ DO ARTIGO 477 DA CLT. DÚVIDA QUANTO À LEGITIMIDADE. A dúvida concernente à legitimidade para o recebimento das verbas rescisórias não se constitui em fato impeditivo para que a reclamada adotasse outra medida a fim de adimplir a obrigação. Neste sentido, cabível no caso concreto ter a recorrente se utilizado da Ação de Consignação em Pagamento (artigo 890 do CPC), com fundamento no inciso IV do artigo 335 do CC/02 ("se houver dúvida sobre quem deva legitimamente receber o objeto do pagamento"). Assim não procedendo, correta a aplicação da multa prevista no § $8^{\circ}$ do artigo 477 da CLT, porque ultrapassado o prazo legal.,"106

Um outro caso diz respeito à obrigação legal de o empregador anotar o contrato de trabalho na Carteira de Trabalho e Previdência Social (CTPS). Considerou-se irrelevante que o empregado não tenha entregue o documento para as devidas anotações na época própria. Parece, portanto, que mesmo que a culpa pelo descumprimento da regra seja atribuível ao empregado, a omissão do empregador ainda assim é tida por ilícita. In verbis:

\footnotetext{
${ }^{104}$ BRASIL. Tribunal Regional do Trabalho da Primeira Região. Recurso Ordinário número 0000870-78.2010.5.01.0022, da $1^{\text {a }}$ Turma. Rio de Janeiro, RJ, 05.03.2013. Disponível em <http://bd1.trt1.jus.br/xmlui/bitstream/handle/1001/467572/00008707820105010022\%2319-032013.pdf?sequence $=1 \&$ \&search $=$ justo $>$. Acessado em 03.08.2013.

${ }^{105}$ Exemplos de acórdãos lidos em que houve aplicação da multa independente das circunstâncias do caso concreto: 0000935-22.2011.5.01.0060 - DOERJ 03-07-2013, Relator / Redator designado: Angelo Galvao Zamorano; 0148900-46.2002.5.01.0342 - DOERJ 23-01-2013, Relator / Redator designado: Roberto Norris; 0000934-14.2011.5.01.0003 - DOERJ 03-072013, Relator / Redator designado: Mirian Lippi Pacheco; 0001058-43.2011.5.01.0020 DOERJ 17-05-2013, Relator / Redator designado: Mirian Lippi Pacheco; 000108183.2011.5.01.0021 - DOERJ 21-02-2013, Relator / Redator designado: Marcelo Antero de Carvalho.

${ }^{106}$ BRASIL. Tribunal Regional do Trabalho da Primeira Região. Recurso Ordinário número 0000934-14.2011.5.01.0003, da $5^{a}$ Turma. Rio de Janeiro, RJ, 17.06.2013. Disponível em <http://bd1.trt1.jus.br/xmlui/bitstream/handle/1001/491090/00009341420115010003\%2303-072013.pdf?sequence=1\&\#search=multa 477 consignação $>$. Acessado em 03.08.2013.
} 
"Insurge-se a reclamada contra a determinação de proceder aos registros do contrato de trabalho, argumentando que não lhe foi apresentada a CTPS para respectivas anotações.

(...)

o registro do contrato de trabalho é imposição do art. 29 da CTPS, que estabelece o prazo de quarenta e oito horas para as devidas anotações, sendo certo ser do empregador a obrigação de fazê-las.

Trata-se de obrigação de fazer da qual o empregador não poderá se eximir, sob pena de responder pelas contribuições não recolhidas, considerando-se que cabe a ele a responsabilidade pelo regular recolhimento.”107

Outra situação em que ficou clara a opção pela segurança da aplicação da regra em detrimento da justiça do resultado foi o seguinte, que versa sobre aplicação da prescrição:

"PRESCRIÇÃO é instituto de proteção, garantindo prevalência à segurança, em detrimento da justiça. Porque se o justo não é perseguido ao tempo certo, a ordem jurídica, em favor da estabilização social, fica com a segurança.,"108

Dando prevalência a um resultado justo, encontramos o seguinte julgado:

“a ata de fls.38 registra a presença de sua preposta 14 minutos após o início da audiência, não havendo, ao contrário do que dito no recurso, qualquer prazo de tolerância para o atraso da parte.

Todavia, os documentos de fls.51 revelam, principalmente o segundo a despeito de pouco legível - a necessidade do comparecimento da preposta (...) (v. ata de fls.35) ao hospital onde sua mãe estava internada, tendo o fato ocorrido nos dias 16, 17 e 18.

Conquanto os documentos em tela não guardem relação com as rigorosas exigências contidas na Súmula 122, entendo que merecem crédito, na medida em que emanadas de Órgão Público, e expressam motivo razoável e justo a justificar o atraso de 14 minutos da preposta à audiência designada."109

Note-se que a pesquisa foi realizada por amostragem, de forma exemplificativa, razão pela qual não se poderia extrair uma conclusão certa e determinada a respeito do problema ora enfrentado, mas apenas indícios de uma prática decisória menos particularista que formalista. Desse modo, um

\footnotetext{
${ }^{107}$ BRASIL. Tribunal Regional do Trabalho da Primeira Região. Recurso Ordinário número 008402005-012-01-00-0, da $9^{\text {a }}$ Turma. Rio de Janeiro, RJ, 04.04.2006. Disponível em <http://bd1.trt1.jus.br/xmlui/bitstream/handle/1001/31843/00840006920055010012\%2328-042006.pdf? sequence $=1 \&$ \&search=prova e ilícita $>$. Acessado em 03.08.2013.

${ }^{108}$ BRASIL. Tribunal Regional do Trabalho da Primeira Região. Recurso Ordinário número 0112300-83.2009.5.01.0082, da $9^{a}$ Turma. Rio de Janeiro, RJ, 09.04.2013. Disponível em <http://bd1.trt1.jus.br/xmlui/bitstream/handle/1001/476557/01123008320095010082\%2319-042013.pdf?sequence $=1 \&$ \& 2 search $=$ justo $>$. Acessado em 03.08.2013.

${ }^{109}$ BRASIL. Tribunal Regional do Trabalho da Primeira Região. Recurso Ordinário número 0295700-60.2009.5.01.0451, da $1^{\text {a }}$ Turma. Rio de Janeiro, RJ, 12.12.2012. Disponível em <http://bd1.trt1.jus.br/xmlui/bitstream/handle/1001/457334/02957006020095010451\%2328-012013.pdf?sequence=1\&\#search=justo $>$. Acessado em 03.08.2013.
} 
questionário que fosse submetido aos juízes poderia se aproximar mais do que de fato ocorre, seguindo os exemplos já citados de experimentos realizados nos Estados Unidos. E é a esse trabalho que nos dedicamos a seguir, explorando também o paradoxo abstrato/concreto.

\subsection{1}

\section{Experimentos em Ética: o Paradoxo Abstrato/Concreto}

Foi visto que o experimento com cidadãos demonstrou que, de maneira geral, há uma inclinação para a concepção substantiva de Estado de Direito, que inclui a justiça e valores morais no conceito e potencialmente legitima decisões particularistas. Observou-se, ainda, que, no contexto da Justiça do Trabalho, em que muitas são as situações de necessidade de utilização de argumentos morais, uma análise por amostragem dos acórdãos do Tribunal Regional do Trabalho da Primeira Região indica que, nos casos de sobreinclusão e subinclusão, prevalece a postura formalista. Note-se que não se trata do formalismo que considera o sistema jurídico completo e preciso, mas o formalismo defendido por Schauer e Struchiner, que reconhece que nem sempre o Direito é determinado mas, quando o é, deve ser aplicado, mesmo que gere resultados subótimos.

Para corroborar essa hipótese, de que os magistrados são mais formalistas que particularistas, foram elaborados questionários para submissão aos juízes trabalhistas fluminenses. Entretanto, a pergunta realizada de forma abstrata, referente ao que prevalece em caso de choque - se a justiça ou a regra jurídica não é capaz de captar integralmente a prática decisória em caso de sobreinclusão e subinclusão. Isso porque, muitas vezes, a resposta à pergunta em tese é uma e, diante do caso concreto, as pessoas decidem de forma contrária. Por exemplo, experimentos ${ }^{110}$ demonstraram que as pessoas tendem a considerar que um agente não é responsável quando a pergunta é realizada de forma abstrata, mas o responsabilizam em um caso concreto que versa sobre a mesma conduta em idêntica situação. A única diferença diz respeito ao fato de que os casos não são descritos de forma idêntica.

\footnotetext{
${ }^{110}$ MANDELBAUM, Eric e RIPLEY, David. Explaining the abstract/concrete paradoxes in moral psychology: the NBAR hypothesis. Disponível em $<$ http://people.fas.harvard.edu/ mandelbaum/NBAR\%20published\%20Authors\%20copy.pdf >. Acessado em 28.02.2013.
} 
Teorias buscam explicar por que a resposta aos questionários é muito diferente quando a pergunta é realizada de forma concreta e quando feita em abstrato. Essa diferença é denominada “paradoxo abstrato/concreto",111, em razão da inconsistência entre as respostas das pessoas. O que é concreto varia de caso para caso: às vezes temos por concreta uma situação que é descrita com mais detalhes, que antes não haviam sido descritos; às vezes o concreto diz respeito a um caso particular ao invés de um caso geral; às vezes descreve-se uma conduta que acontece no nosso mundo e outra que ocorre num mundo alternativo, sendo que ainda há outros usos dos termos abstrato e concreto nos estudos da psicologia social. $^{112}$

Em um experimento realizado por De Brigard, Mandelbaum e Ripley, publicado em 2009, foram entregues dois tipos de vinhetas aos participantes. Uma dizia que Dennis tinha recentemente descoberto, do seu médico, que tinha um problema neurológico, o que tinha feito com que ele agisse de determinada forma. Qualquer pessoa que apresentasse esse tipo de problema neurológico agiria do mesmo modo que ele, Dennis, agiu. Indagava-se, então: numa escala de 1 a 7, 1 sendo não responsável e 7 sendo muito responsável, o quanto Dennis é moralmente responsável pelos comportamentos que foram causados pelo seu problema neurológico?

Essa era a questão abstrata, porque a ação que o agente cometeu não vinha especificada. Em contraste, a outra vinheta dizia que Dennis tinha recentemente descoberto, do seu médico, que tinha um problema neurológico, o que tinha feito com que, no passado, estuprasse mulheres. Qualquer pessoa que apresentasse esse tipo de problema neurológico agiria do mesmo modo que ele, Dennis, agiu. Indagava-se, então: numa escala de 1 a 7, 1 sendo não responsável e 7 sendo muito responsável, o quanto Dennis é moralmente responsável pelos estupros que cometeu? Os resultados confirmaram o paradoxo abstrato/concreto, pois na questão abstrata, os participantes consideraram Dennis significativamente menos responsável que na questão concreta.

Tenta-se explicar esse paradoxo com base em duas linhas argumentativas: uma calcada nos afetos e outra fundada na cognição. As teorias afetivas, como o próprio nome indica, têm como base as emoções dos participantes. Os teóricos

\footnotetext{
${ }^{111}$ Idem, p. 01.

112 Idem, p. 01.
} 
divergem com relação aos detalhes do envolvimento emocional, mas em linhas gerais, pode-se dizer que eles defendem que o que faz com que seja atribuída uma responsabilidade maior nas questões concretas é o maior envolvimento emocional provocado por essas últimas.

Parece razoável assumir que a menção a um estupro produz uma comoção maior nos participantes se comparada à ausência de referência à conduta reprovável. Além disso, há evidência de que um alto envolvimento emocional pode aumentar a imputação de responsabilidade, até mesmo quando o julgamento é concernente a casos não relacionados ao que aumentou o envolvimento emocional antes. Lerner, Golberg e Tetlock ${ }^{113}$ realizaram um experimento em que os participantes, duzentos e noventa e um estudantes de psicologia, foram levados a acreditar que estavam participando de três estudos sem conexão um com o outro. O primeiro solicitava que os participantes completassem um questionário com informações demográficas, o segundo era referente a um vídeo que deveria ser assistido e o terceiro dizia respeito a um questionário para ser lido e respondido. Os resultados demonstraram que os participantes expostos a uma situação de raiva antes de responder ao questionário referente ao julgamento moral atribuíram mais responsabilidade do que aqueles expostos a uma situação emocionalmente neutra antes.

As teorias cognitivas são aquelas que elegem como causa principal do paradoxo não a emoção, mas um estado de consciência (como uma crença) ou um processo cognitivo (como a memória). Pode-se citar como exemplo a hipótese das capacidades separadas, que defende que nós tendemos a pensar de forma diferente em situações abstratas e em situações concretas. Assim, a concretude nos faria acessar um determinado mecanismo mental específico, sem que o envolvimento emocional seja decisivo para configurar o paradoxo ${ }^{114}$.

Haveria, segundo essa teoria, uma memória semântica e outra episódica. A primeira processaria as questões abstratas, já que seria um tipo de memória em

\footnotetext{
${ }^{113}$ LERNER, Jennifer S., GOLDBERG, Julie H. e TETLOCK, Philip E. Sober second thought: the effects of accountability, anger and authoritarianism on attributions of responsibility. In Personality and social Psychology Bulletin. 1998; 24:563-574. Disponível em $<$ http://numerons.files.wordpress.com/2012/04/08-attributions-of-responsibility.pdf $>$. Acessado em 05.02.2014.

${ }^{114}$ Sinnot-Armstrong, W. Abstract + Concrete $=$ Paradox. In Experimental Philosophy (J. Knobe e S. Nichols, coord.). Nova Iorque: Oxford University Press, 2008.
} 
que os dados são armazenados na forma de sentenças propositivas. Ilustrativamente: se há determinismo, então as pessoas não são responsáveis por seus atos. A segunda armazena dados como episódios fenomenológicos. Assim, se alguém decide matar outra pessoa e alega que não poderia ter agido diferente em razão da enfermidade que possui, há atuação da memória episódica, embora haja certa representação na memória semântica referente a questões abstratas. Logo, essas duas memórias interagem de uma forma que acaba por produzir o paradoxo abstrato/concreto.

A segunda teoria cognitiva a ser ressaltada é a NBAR (norm broken, agent responsible, cuja tradução livre é: norma violada, agente responsabilizado). Ela não se embasa em uma arquitetura cognitiva diferente para cada tipo de questão, mas sim num conjunto de crenças contraditórias que geram o paradoxo. Essas crenças se apresentam mais salientes nos casos concretos.

Defende-se que as pessoas possuem uma crença inconsciente de que sempre que uma norma é violada, um agente deve ser responsabilizado (NBAR). Acontecimentos ruins são aqueles em que uma regra é desrespeitada (a regra de que coisas ruins não devem acontecer). Se ocorre um desses eventos ruins, as pessoas concluem que alguém é responsável pelo fato. De acordo com essa teoria, até mesmo ações concretas que não causam um mal, mas se desviam do ordinário, resultariam em atribuição de responsabilidade, embora em grau menor.

Dessa forma, considerando-se que é mais evidente a violação de uma norma num caso concreto que num abstrato, espera-se que uma dissonância com a crença já dita seja maior na situação concreta e essa dissonância (contradição entre as expectativas e o que de fato ocorreu) pode ser resolvida por meio de uma responsabilização mais forte do agente.

Segundo seus defensores, essa teoria também é capaz de explicar a antropomorfização de objetos inanimados, que acontece quando tais objetos não estão funcionando da forma que se esperava, circunstância que não ocorre quando funcionam como deveriam. Por exemplo: se o seu computador começa a apresentar problemas durante a digitação de um trabalho importante, a probabilidade de que você o xingue, como se fosse uma pessoa que estivesse escutando, é grande. Já se funciona normalmente, dificilmente você o tratará 
como se fosse uma.

Afirma-se que, mesmo sem um conceito de norma (norma violada, agente responsabilizado), a teoria dá uma base para entender o paradoxo abstrato/concreto, na medida em que se pode aferir quais expectativas que, quando frustradas, levam as pessoas a responsabilizar outras. As normas que seriam desrespeitadas, portanto, seriam aquelas que frustrariam as expectativas das pessoas, expectativas essas no sentido mais amplo possível.

Como se pode ver, cada uma dessas teorias está embasada em uma única causa, mesmo que preponderante, para explicar o paradoxo. Entretanto, muitas vezes os afetos são objeto de ponderação racional e a decisão que acaba prevalecendo pode não ser decorrente preponderantemente do envolvimento emocional. Por outro lado, a teoria das capacidades separadas não explica o porquê de haver uma resposta distinta quando a questão é formulada de forma abstrata ou concreta. Apenas aponta o modo como entende acontecer o processamento mental dessas questões. E a ideia de NBAR não explica os resultados obtidos com o questionário que foi submetido, por meio desse estudo, aos juízes de primeira instância do Tribunal Regional do Trabalho da Primeira Região, como se verá mais adiante.

Parece, ao contrário, que não há uma causa única que seja capaz de explicar todo paradoxo. Joshua Knobe e John M. Doris ressaltaram que não é possível aplicar um único critério para todos os julgamentos morais. ${ }^{115}$ Supõe-se que se possa dizer o mesmo no que se refere ao paradoxo abstrato/concreto. Esses autores afirmaram que a ideia de prática usual extraída do estudo de Strawson é utilizada por pesquisadores para corroborar sua tese e rechaçar outras teorias. Entretanto, isso acaba por gerar uma aniquilação mútua, já que realiza-se um experimento que corrobora uma determinada hipótese, a qual é muitas vezes conflitante com a confirmada por outro.

O problema, continuam, está no fato de que essas pesquisas partem do pressuposto de que um único critério pode explicar todos os casos de julgamento moral (assuption of invariance ou teorias não variantes). Estudos experimentais

\footnotetext{
${ }^{115}$ KNOBE, Joshua \& DORIS, John M. Strawsonian variations: folk morality and the search for a unified theory. In The handbook of moral psichology. Oxford: Oxford University Press, 2007. Disponível em <http://www.unc.edu/ knobe/Knobe-Doris.pdf >. Acessado em: 04.03.2013.
} 
indicam que as pessoas não utilizam um único critério de julgamento. Há variação segundo se trate de um estranho ou um amigo, segundo se apresente o caso de uma forma ou de outra, etc.

Veja-se, por exemplo, a questão do nexo causal. Sabe-se que o julgamento de causalidade tem um papel importante sempre que as pessoas estão buscando responsabilizar moralmente alguém. Assim, afere-se se determinado agente foi quem causou o dano. Mas há evidências de que, para aferir a própria causalidade, não se utiliza um único critério. Ao contrário. Há indícios de que o critério varia dependendo do status moral da conduta.

No estudo experimental realizado por Alicke e outros (1992), foi entregue aos participantes uma estória sobre um agente que estava dirigindo para casa acima do limite permitido na via. Para alguns participantes, dizia-se que o agente o fazia porque precisava chegar em casa rápido para esconder um presente que havia comprado para seus pais. Para os demais, ele precisava chegar em casa para esconder cocaína. Em ambos os casos, o agente acaba se envolvendo num acidente. Note-se que o acidente é o mesmo, variando apenas a intenção de esconder um presente ou a cocaína. A pergunta dizia respeito ao grau em que o agente havia causado o acidente em razão de estar dirigindo muito rápido.

A divergência nas respostas foi significativa: os participantes tenderam a dizer que o agente causou o acidente em maior grau na situação em que ele extrapolava o limite de velocidade para esconder cocaína. Resultados similares podem ser encontrados em outros estudos (Alicke 2000; Alicke et al. 1994; Solan and Darley 2001), parecendo que considerações morais (informações boas ou ruins a respeito do agente) têm um impacto importante no julgamento causal relacionado à atribuição ou não de responsabilidade moral.

Assim como a causalidade parece não estar relacionada a um único critério, supõe-se que não se pode atribuir o paradoxo abstrato/concreto a uma única causa. Diversos são os fatores que podem atuar ditando distintas respostas aos casos narrados. Pode ser que num determinado caso a atuação do fator emocional seja mais forte e, no outro, a crença de que, se uma norma foi violada, alguém deve ser responsabilizado (NBAR).

De toda sorte, saber quais aspectos possuem um papel relevante nos 
julgamentos é importante não só para compreender os julgamentos morais, mas também os judiciais. Nota-se que isso ocorre com o envolvimento emocional e com determinados aspectos cognitivos. Assim, permite-se que se possa melhor exercer a atividade judicante, advocatícia e a própria cidadania.

\subsection{2}

\section{Justo e o Legal na Ótica dos Juízes Trabalhistas Fluminenses}

\subsubsection{1 Visão Geral e Método}

A ideia de estudar a tensão entre legalidade e justiça nas decisões judiciais da primeira instância do Tribunal Regional do Trabalho da Primeira Região tem por propósito focar em casos de sobreinclusão e de subinclusão da regra ${ }^{116}$. Tratase, pois, daquela decisão judicial que resolve um caso que comporta dois tipos de solução: uma decorrente de uma simples subsunção da situação concreta à regra, chamada solução “legal”, outra decorrente da justiça do resultado, superando-se a regra em prol de uma solução justa.

Desse modo, o objetivo é de identificar, por meio de questionários aplicados aos juízes da primeira instância do Tribunal Regional da Primeira Região, se prevalece a aplicação da regra ou o resultado justo, em caso de choque entre um e outro. Foca-se na prática decisória, não no conceito de Direito. Assim, o estudo poderá informar se o julgamento tende para o formalismo ou para o particularismo. Pretende-se, também, observar se há distinção entre a postura dos juízes frente uma questão posta em abstrato e uma questão concreta, como provou-se existir no experimento realizado com cidadãos leigos já citado ${ }^{117}$.

\footnotetext{
116،“A generalidade, por sua vez, é responsável pelo fenômeno da subinclusão ou sobreinclusão das regras ou pela sua potencial sobreinclusão ou subinclusão. É o fato de as regras prescritivas incorporarem mais casos do que deveriam, ou deixarem de incorporar casos que deveriam incorporar para concretizar as suas justificações subjacentes, que torna o direito, ou melhor, a prática jurídica, um terreno de opções ou escolhas.” STRUCHINER, Noel. O direito como um campo de escolhas: por uma leitura das regras prescritivas como relações. In Nas fronteiras do formalismo: a função social da dogmática jurídica hoje. RODRIGUES, José Rodrigo; DA SILVA E COSTA, Carlos Eduardo Batalha e BARBOSA, Samuel Rodrigues, organizadores. Rio de Janeiro: Editora Saraiva, 2009, p. 104.

${ }^{117}$ Notou-se que, de forma abstrata, os cidadãos conferiam uma importância ao respeito às regras maior que quando confrontados com um caso concreto, já que nestes teve maior relevância a justiça do resultado. SCHWEITZER, N. J.; SYLVESTER, Douglas J. e SAKS, Michael J. Rule violations and the rule of law: a factorial survey of public attitudes. Disponível em $<$ http://papers.ssrn.com/sol3/papers.cfm?abstract_id=951005 > . Acessado em 28.02.2013.

SCHWEITZER, N. J.; SAKS, Michael J. e LOVIS-MCMAHON, David. Is the rule of law a law of rules? Judgments of rule of law violations. Disponível em $<$ http://papers.ssrn.com/sol3/papers.cfm?abstract_id=1439055>. Acessado em 28.02.2013.
} 
Note-se que, no âmbito da pesquisa empírica realizada com cidadãos não integrantes do Poder Judiciário, focou-se na questão conceitual: prevalência de uma visão formal do Estado de Direito, que valoriza a regra proveniente das fontes tradicionais, ou de uma visão substantiva, que acolhe a justiça do resultado como parte integrante do Estado de Direito. Houve a descrição de uma situação concreta e da decisão da autoridade, que foi avaliada pelos participantes como sendo ou não apropriada.

No estudo ora realizado, o foco é distinto, porque descreve a situação e não diz de antemão qual foi a decisão judicial. Procura-se saber qual seria a decisão do magistrado se confrontado com aquela questão (abstrata em algumas vinhetas e concreta em outras). A pergunta é, pois, direta: qual é a opção do magistrado.

Desse modo, não se está querendo estudar o conceito de Direito ou de Estado de Direito do juiz, mas sim sua prática decisória. Note-se que, enquanto que o formalismo e o particularismo podem ser bem analisados sob a ótica do agente responsável pela decisão, já que podem retratar o que se passa no Judiciário, o conceito de Estado de Direito tem sua importância sob a ótica dos jurisdicionados, ou seja, das pessoas que são afetadas pelas decisões particularistas ou formalistas. Isso porque a relevância do conceito de Estado de Direito decorre de sua função legitimadora do Estado. E a legitimidade de uma decisão, seja ela particularista ou formalista, deve ser observada, para uma melhor compreensão do problema, sob a perspectiva do cidadão comum, não de quem decide. Uma outra pesquisa seria tentar extrair o conceito de Estado de Direito adotado pelos magistrados e cotejá-lo com a prática decisória, de modo a extrair se existe ou não concordância entre uns e outros. No entanto, não é a esse estudo que nos dedicamos no presente.

A pesquisa é qualitativa, com o estudo do caso referência mencionado, na perspectiva de confirmar ou rechaçar as hipóteses levantadas. O recorte espacial e institucional para o referido caso-referência foi o da primeira instância do Tribunal Regional do Trabalho da Primeira Região (Rio de Janeiro).

Visando estudar a prevalência das razões jurídicas ou morais no âmbito da primeira instância do Tribunal Regional do Trabalho da Primeira Região em casos

MANDELBAUM, Eric e RIPLEY, David. Explaining the abstract/concrete paradoxes in moral psychology: the NBAR hypothesis. Disponível em $<$ http://people.fas.harvard.edu/ mandelbaum/NBAR\%20published\%20Authors\%20copy.pdf>. Acessado em 28.02.2013. 
de sobre e subinclusão, a pesquisa empírica adotou como técnica de levantamento de dados a aplicação de questionários semi-estruturados ${ }^{118}$ a juízes, sendo indagadas em algumas vinhetas uma questão abstrata e, em outras, uma referente a um caso concreto. Ambas as questões tinham por objetivo avaliar se prevalece a justiça do resultado ou a aplicação da regra legal, considerando-se o recorte temporal julho/2013 a janeiro/2014. Finalizou-se com informações demográficas dos juízes participantes.

A questão abstrata diz respeito à indagação realizada diretamente ao juiz, se ele opta pela aplicação da regra legal ou da justiça do resultado em caso de conflito entre um e outro. No que se refere à concreta, optou-se por eleger dois casos de modo a se aferir se os resultados se confirmam; se são semelhantes em ambos. O primeiro deles narra uma situação em que há uma prova ilícita. Obedecendo-se a regra de proibição de utilização de tal prova, o resultado acaba por ser injusto. Superando-se a regra e adotando-se a prova ilícita, chega-se a um veredito justo. A ideia da prova ilícita foi inspirada no experimento citado na introdução ${ }^{119}$, adequando-o à matéria trabalhista, que é aquela sobre a qual decidem os juízes participantes.

A situação apresentada é de uma empregadora que viola o sigilo de correspondência de sua doméstica e descobre que a empregada estava lhe furtando dinheiro. A única prova do furto - a carta - é, portanto, ilícita. Ora, a regra que estabelece o sigilo de correspondência foi criada para proteger a privacidade. Desse modo, pode-se deduzir que a justificação que lhe é subjacente é de permitir que as pessoas se comuniquem sem que terceiros estejam aptos a saber do que se trata. Contudo, a regra não tem como finalidade permitir que as pessoas utilizem essa privacidade para se comunicar sobre crimes. A regra no caso inviolabilidade da correspondência - abarca mais do que deveria, porque está protegendo a situação em que há utilização de carta para falar com terceiro sobre um ilícito penal. Quando a norma jurídica engloba mais do que deveria ocorre, como visto, sobreinclusão.

\footnotetext{
${ }^{118}$ MINAYO, Maria Cecília de Souza (Org.). Pesquisa social: teoria, método e criatividade. 20 ed. Rio de Janeiro: Vozes, 1994.

${ }^{119}$ SKITKA, Linda e HOUSTON, David. When due process is of no consequence: Moral mandates and presumed defendant guilt or innocence. 14 (3) Soc. Just. Res. 305 (2001) Apud SCHWEITZER, N. J.; SAKS, Michael J. e LOVIS-MCMAHON, David. Is the rule of law a law of rules? Judgments of rule of law violations. Disponível em $<$ http://papers.ssrn.com/sol3/papers.cfm?abstract_id=1439055>. Acessado em 28.02.2013.
} 
O segundo caso concreto versou sobre o tema da revelia e foi extraído, com algumas alterações, de um julgado acima mencionado, que foi identificado na pesquisa realizada na biblioteca digital do Tribunal Regional da Primeira Região. Procurou-se seguir o mesmo padrão nos dois questionários “concretos”, com utilização do mesmo número de palavras e da mesma forma de questionar. Assim como na primeira situação concreta, narra-se um caso em que há uma regra processual sedimentada pela lei ou pela jurisprudência, de cuja aplicação se extrai um resultado injusto. Na situação, a empregadora havia pago as verbas rescisórias e tais verbas eram postuladas novamente na Justiça. No entanto, no dia da audiência em que seria apresentada a defesa e os documentos comprobatórios do pagamento, a sócia principal da empresa atrasou quinze minutos, porque estava acompanhando seu pai, internado em um hospital. Para elidir a revelia, o enunciado da Súmula 122 do Tribunal Superior do Trabalho exige que haja apresentação de atestado médico do próprio representante da pessoa jurídica e que esse atestado informe a impossibilidade de locomoção. Como se percebe, o atestado do pai da sócia não está enquadrado no entendimento sumulado, que para os fins desse trabalho é apresentado como uma regra.

Percebendo-se a justificação subjacente à norma como sendo de evitar aplicação da penalidade (revelia) quando o atraso ou a ausência na audiência não ocorreu em virtude de culpa da parte revel, nota-se que a regra jurídica nesse caso abarca menos casos do que deveria, já que o atraso da mencionada sócia não ocorreu por sua culpa. Além disso, foi de apenas quinze minutos. Trata-se, desse modo, de uma situação de subinclusão, na qual a regra deixa de abarcar uma situação que deveria para realizar sua finalidade subjacente. Desse modo, se o primeiro caso concreto diz respeito a sobreinclusão, esse outro é concernente à subinclusão.

Nos três casos, a pergunta foi realizada diretamente ao juiz, aferindo-se o que ele faria diante daquela situação. Não há pergunta indireta, se a decisão narrada é ou não apropriada, como no caso dos cidadãos que não integram o Judiciário. A ideia é cotejar os resultados do experimento anterior já mencionado com os do realizado por este estudo, com adequações exigidas na medida da diferença entre os participantes.

A hipótese era de que a superação da regra legal seria exceção e, mesmo em casos claros que comportam uma avaliação moral distinta da formal, a prevalência 
seria de aplicação da regra. Também se supôs que com a questão posta em abstrato, os juízes seriam mais formalistas que com a questão posta em concreto. Isso significaria que, em tese, a prevalência da regra legal sobre a justiça do resultado é maior em abstrato.

Esperava-se que os resultados obtidos com experimentos realizados com cidadãos comuns fossem distintos daqueles obtidos com os juízes, já que, mesmo diante de um caso concreto, supõe-se a prevalência de uma postura judicial formalista, enquanto que, em caso de sobreinclusão ou subinclusão, os cidadãos priorizaram a justiça do resultado em detrimento da aplicação da regra ${ }^{120}$.

\subsubsection{2}

\section{Dados e Resultados}

Dos cerca de 240 juízes trabalhistas existentes na primeira instância do caso referência, 69 responderam o questionário (cerca de 25\% do total), sendo 57 das respostas efetivadas em papel e 12 por mensagem eletrônica.

Inicialmente, os questionários não seriam aplicados de forma virtual (email). Mas, para permitir a participação de juízes que estavam de férias ou que estavam atuando, por exemplo, no interior, foram enviadas mensagens eletrônicas, com o termo de consentimento no corpo das mesmas. As informações demográficas e a questão (que poderia ser uma das três, aleatoriamente) foram anexados como documentos à parte.

Dos participantes, 42 eram do sexo feminino (60,87\%) e 27 do masculino (39,13\%), com idade média de 44,06 anos. Quanto ao tempo de atividade jurisdicional, 11,59\% dos juízes tinham menos de 5 anos, 23,19\% de 5 a 10 anos, 23,19\% de 10 a 15 anos e 42,03\% contavam com mais de 15 anos, o que permite concluir que a maioria dos participantes está no exercício de suas atividades há mais de 10 anos.

Quanto à orientação política, 17,39\% informaram ser de "esquerda”, 30,43\% de “centro-esquerda”, 20,29\% do “centro”, 7,25\% de “centro-direita” e

\footnotetext{
${ }^{120}$ SCHWEITZER, N. J.; SYLVESTER, Douglas J. e SAKS, Michael J. Rule violations and the rule of law: a factorial survey of public attitudes. Disponível em $<$ http://papers.ssrn.com/sol3/papers.cfm?abstract_id=951005 > . Acessado em 28.02.2013.

SCHWEITZER, N. J.; SAKS, Michael J. e LOVIS-MCMAHON, David. Is the rule of law a law of rules? Judgments of rule of law violations. Disponível em $<$ http://papers.ssrn.com/sol3/papers.cfm?abstract_id=1439055>. Acessado em 28.02.2013.
} 
1,45\% de “direita. Alguns não responderam. Denota-se, pois, que a orientação política tende para a esquerda.

No que se refere ao grau de instrução, poucos realizaram cursos de aprofundamento a nível de mestrado e doutorado. A maioria continuou apenas com a graduação após aprovados no concurso público para juiz. Só 28,99\% realizaram curso de pós-graduação, 4,35\% informaram possuir mestrado incompleto, 8,70\% mestrado completo, 4,35\% doutorado incompleto e 2,90\% doutorado completo, num total de 68 respostas a essa indagação.

As razões para esse fato não parecem estar atreladas ao desinteresse dos magistrados, já que na pesquisa da AMB realizada em 2006, grande parte deles entendeu que os mestrados acadêmico e profissional contribuem para o aperfeiçoamento do exercício da função de juiz (apenas 8,8\% e 4,5\% entenderam que o mestrado, respectivamente o acadêmico e o profissional, em nada contribuem) ${ }^{121}$

A maioria dos juízes não leciona (78,26\%), havendo 6 que responderam ministrar aulas em faculdades, 6 em cursos jurídicos preparatórios, 5 em escola de magistratura e 3 em outras instituições. Alguns, portanto, lecionam em mais de uma dessas opções.

No que concerne ao grau de instrução dos pais, só 1 informou possuir um dos genitores (no caso, a mãe) sem instrução. Os pais da maioria possui superior completo $(66,67 \%)$ e as mães, na maioria, iniciaram o curso de graduação, sendo que 47,83\% o concluíram e 7,25\% não concluíram. Em termos de conhecimento, pois, a maioria dos juízes vêm de famílias que tiveram um grau de instrução elevado para a média nacional. ${ }^{122}$

Quanto às três questões principais, a pergunta abstrata foi respondida por 31,88\% participantes. Ela foi formulada nos seguintes termos:

Em determinado caso pendente de decisão, a regra legal aplicável geraria um resultado injusto, segundo seu ponto de vista. o(a) Senhor(a) optaria:

\footnotetext{
${ }^{121}$ SADEK, Maria Tereza. Pesquisa AMB 2006. A palavra está com você. Resultados. Disponível em <http://www.amb.com.br/portal/docs/pesquisa2006.pdf >. Acessado em 05.02.2014.
${ }^{122} \mathrm{~A}$ esse respeito, ver informações do IBGE disponíveis em <ftp://ftp.ibge.gov.br/Indicadores_Sociais/Sintese_de_Indicadores_Sociais_2013/pdf/educacao _pdf.pdf $>$. Acessado em 25.01.2014.




$$
\text { ( ) pelo resultado justo ～～～） pela aplicação da regra legal }
$$

Abaixo deixou-se um espaço para justificativa, indicando-se que era opcional. Veja-se a demonstração gráfica das respostas:

Demonstração Gráfica Quanto à Incidência

das Respostas dos Juízes na Questão Abstrata

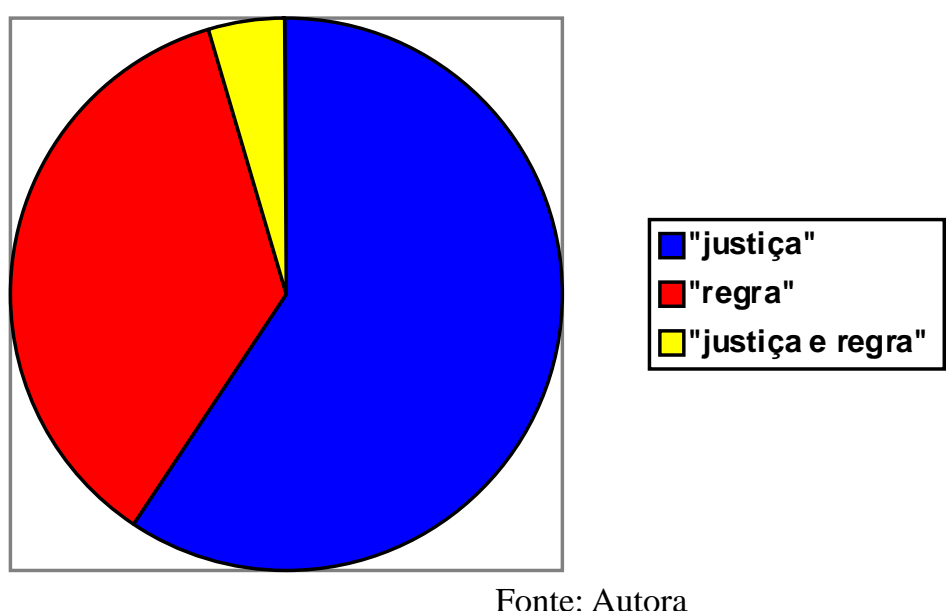

Os juízes participantes ficaram divididos nessa pergunta, não confirmando a hipótese inicialmente levantada. A ideia de que eles optariam, em sua maioria, pela aplicação da regra, foi substituída pelo fato de que, na verdade, 59,09\% optou pela justiça do resultado e 36,36\% pela regra, havendo 1 que marcou ambas as opções.

Houve caso de opção pela regra legal observando-se no espaço de “justificativa” a exceção referente a situações absurdas. Desse modo, houve certo equilíbrio entre o resultado justo e a regra legal, sendo que mais participantes optaram pelo primeiro.

No primeiro caso concreto, da prova ilícita, a questão foi formulada da seguinte forma:

Numa relação de trabalho doméstico, Maria estava furtando dinheiro de sua empregadora, Fátima. Chegou a furtar mais de R\$ 5.000,00. Dispensada, Maria ajuizou reclamação trabalhista requerendo as verbas rescisórias decorrentes da dispensa sem justa causa, pois considerava que Fátima não poderia comprovar o furto.

A reclamada, Fátima, alegou justa causa para a demissão, afirmando que a 
reclamante estava furtando dinheiro de sua residência e juntou como prova de suas alegações uma carta escrita por Maria e que seria enviada a uma amiga. Na carta, Maria afirmava que "estou conseguindo roubar um bom dinheiro da patroa e em breve vou poder pagar o empréstimo que te devo. Fique tranquila porque ela nem desconfia! Estou pegando aos poucos e sem deixar rastro".

A reclamante alegou a ilicitude da prova, que foi reconhecida e declarada incidentalmente pelo juízo, pois a ex-empregadora violou o sigilo de correspondência. Não foi esclarecido como a empregadora teve acesso à carta. Observe-se que a correspondência é a única prova do furto.

Diante disso, o(a) Senhor(a).

( ) optaria pela aplicação da regra da proibição da prova ilícita, julgando procedente o pedido de verbas rescisórias.

( ) optaria pela justiça do resultado, julgando improcedente o pedido de verbas rescisórias, visto que a justa causa de fato ocorreu.

( ) outro:

Também era facultada a justificativa por escrito. Veja-se o gráfico demonstrativo das respostas:

\author{
Demonstração Gráfica Quanto à Incidência \\ das Respostas dos Juízes na Questão Concreta - \\ Prova Ilícita
}

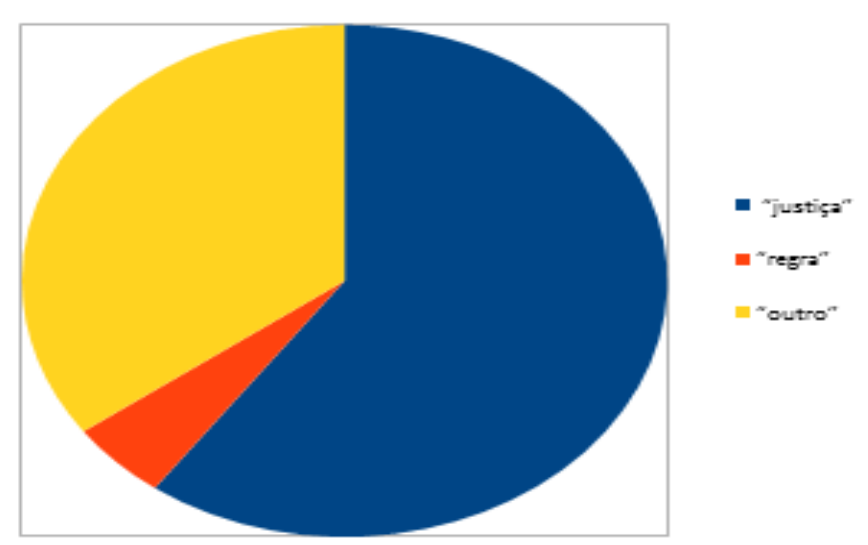

Fonte: Autora

Nesse questionário, embora a primeira hipótese de prevalência da regra não tenha se confirmado, o paradoxo abstrato/concreto foi. Houve resultados globais distintos daqueles da vinheta anterior.

Enquanto na pergunta abstrata os juízes ficaram consideravelmente divididos entre o resultado justo e a regra, aqui a opção foi quase que no total das respostas pela utilização de argumentos morais. Só um participante (5\%) escolheu 
a aplicação da regra, de um total de 20 respondidas. Optaram pelo “outro" 35\% dos magistrados e pelo resultado justo $60 \%$.

Desse modo, a hipótese de que os juízes são mais formalistas em abstrato que em concreto foi confirmada. Alguns que marcaram a terceira opção (“outro”) escolheram reabrir a instrução, colhendo novas provas de modo a garantir a justiça do resultado. Houve um caso em que foi referida a tentativa de conciliação.

Notou-se que todos os que realizaram a escolha da resposta “outro" aduziram razões de substância (consequencialistas ou deontológicas) na justificação, o que significa que, no embate, a opção claramente não foi formalista.

A terceira questão (segunda concreta), referente à aplicação da revelia, corroborou os resultados do primeiro caso concreto. Das 27 respostas $(39,13 \%$ do total), somente uma optou pela regra (no caso, a "regra” dizia respeito a entendimento jurisprudencial consolidado na forma de Súmula que, como vimos, possibilita a utilização de argumentos de autoridade). Vejamos o que foi questionado:

Numa relação de emprego, a empregadora Vendas de Roupas Ltda dispensou Amanda, sua empregada, sem justa causa. Pagou todas as verbas rescisórias.

Após, Amanda ajuizou reclamação trabalhista, alegando que fazia jus a horas extras e que foi dispensada sem nada receber a título de verbas rescisórias. $\mathrm{Na}$ audiência inaugural, a representante da empresa chegou quinze minutos atrasada, quando a reclamante e seu patrono já tinham se retirado.

Peticionou o patrono da empresa, sustentando que o atraso foi de apenas quinze minutos e que ocorreu em virtude de a sócia principal da empresa estar acompanhando seu pai, que se encontrava internado no hospital. Afirmou ainda que as verbas rescisórias foram pagas. Juntou documentos que comprovavam todas as alegações. Entretanto, a Súmula 122 do TST exige, para elidir a revelia, a apresentação de atestado médico do próprio representante da pessoa jurídica, não de seu pai, e que o atestado informe a impossibilidade de locomoção no dia da audiência, o que não ocorreu no caso em tela.

Diante disso, o(a) Senhor(a).

( ) aplicaria a revelia, condenando a empresa inclusive ao pagamento das verbas rescisórias que já haviam sido pagas, porque o atestado não preenche os requisitos exigidos pela Súmula 122, TST, e estava preclusa a produção da prova documental quando de sua apresentação.

( ) não aplicaria a revelia.

( ) outro:

Nesse caso também havia a faculdade de justificar. Veja-se o gráfico 
demonstrativo:
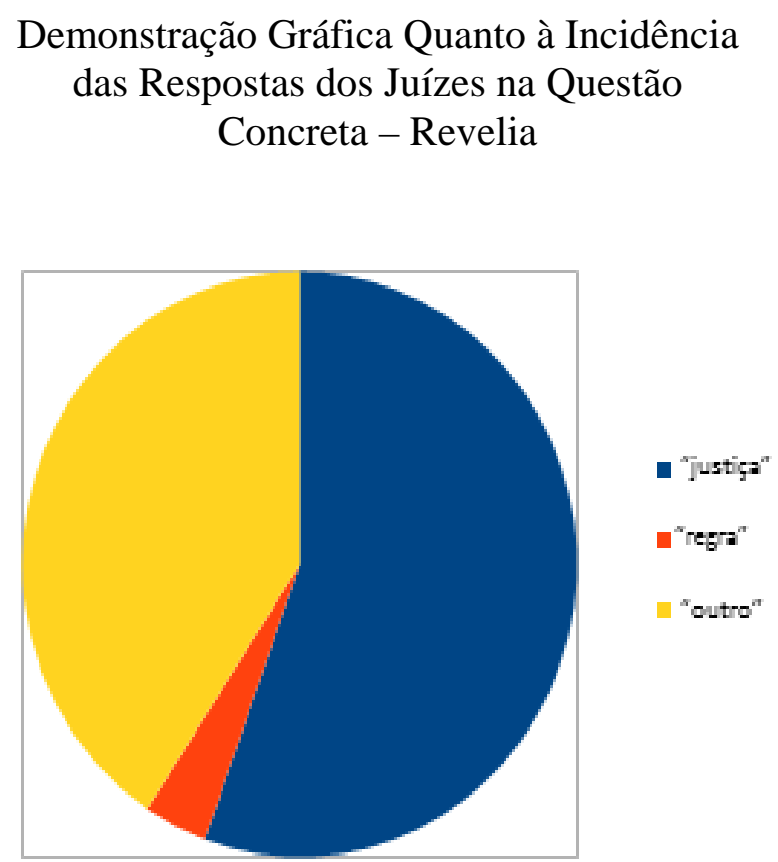

Fonte: Autora

Assim como no experimento anterior, a escolha de "outro" (40,74\%) veio acompanhada de razões de substância, tendo muitas das respostas feito menção ao princípio da vedação ao enriquecimento sem causa e ressaltado a possibilidade de dedução das parcelas pagas a idêntico título. Observou-se que 55,56\% dos juízes escolheram a justiça do resultado.

\subsubsection{3}

\section{Observações Finais}

Neste capítulo, foi analisada a prática decisória dos magistrados trabalhistas de primeira instância especificamente em caso de sobreinclusão e subinclusão, por meio de questionário submetido pela pesquisadora diretamente aos juízes fluminenses, em papel ou mensagem eletrônica. Foi explorado o paradoxo abstrato/concreto: a alguns participantes foi indagada uma questão abstrata, a outros uma concreta. A amostra levou em consideração o tempo de exercício da função, o gênero, a idade, orientação política, grau de instrução do magistrado e de seus pais, além da circunstância de lecionarem ou não.

Observou-se que as decisões são menos formalistas do que se imaginava, visto que houve prevalência da opção pela justiça do resultado $(57,97 \%$ dos 
participantes), com remição aos argumentos morais em 85,51\% das respostas, já que a escolha por nenhuma das duas opções (formalista ou particularista) ou por ambas foi acompanhada invariavelmente de razões de substância, consequencialistas ou deontológicas.

A opção pelos argumentos jurídicos ou de autoridade (que remetem a uma regra ou entendimento jurisprudencial consolidado) foi pequena (14,49\%). Mas os juízes se mostraram mais formalistas em abstrato que em concreto, como se percebe no gráfico a seguir.

Quadro Comparativo das Questões Concretas e Abstrata

Segundo os Critérios de Razões Morais ou Jurídicas

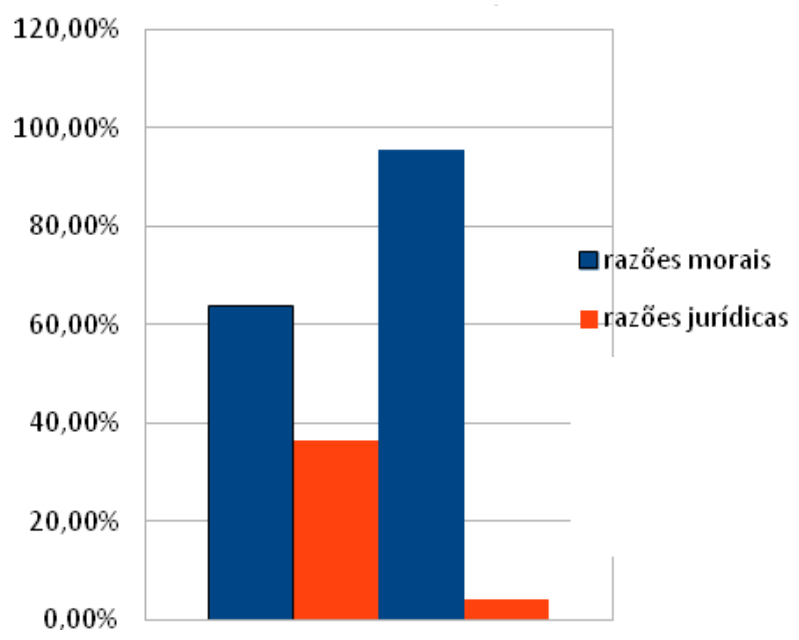

Abstrato Concreto

Fonte: Autora

O quadro demonstra o paradoxo abstrato/concreto, já que diante da mesma situação de sobreinclusão ou subinclusão apresentada de uma maneira ou de outra, a opção pela regra, com utilização de argumentos jurídicos ou de autoridade é substantivamente menor na questão concreta. Como vimos, não há consenso na doutrina das razões para tanto, havendo quem defenda que essa diferença decorre de fatores afetivos e quem diga que provém de fatores congnitivos. De toda sorte, entendemos que não é só um fator específico o responsável pela divergência nas respostas, seguindo a linha das teorias variantes. 
Esses resultados, de prevalência de argumentos morais, estão em consonância com a referida pesquisa publicada em 2002, realizada por Armando Castelar Pinheiro com 741 juízes, em que se indagava aos magistrados com qual de duas proposições eles concordavam mais: (A) que os contratos devem ser sempre respeitados, independentemente de suas repercussões sociais; ou (B) que a busca da justiça social justifica decisões que violem os contratos. A grande maioria dos entrevistados $(73,1 \%)$ respondeu que concordava mais com a segunda alternativa (B). Ora, isso significa que mesmo quando se considera os contratos e não a lei como parâmetro, os juízes optam, majoritariamente, pela justiça, embora nesse caso seja a especificamente a justiça social.

Observou-se naquele estudo que a proporção de adesão à alternativa (B) variava de acordo com a matéria, sendo maior em causas envolvendo meio ambiente, direitos do consumidor, regulação dos serviços públicos e questões trabalhistas e previdenciárias. No que se refere aos litígios comerciais, crédito e aluguel de imóveis, prevaleceu a alternativa (A). A pesquisa ressaltou que existe uma tentativa do magistrado de proteger a parte mais fraca na disputa que lhe é apresentada, indicando que esse fator é o responsável pela diferença nas respostas de acordo com a matéria. Como o nosso estudo é realizado na Justiça do Trabalho, as conclusões foram em parte confirmadas, só que dessa vez com o diferencial de utilização de questão concreta, não apenas abstrata como no estudo anterior, considerando-se, ainda, a referência imediata a uma regra, não aos contratos.

Além da constatação da prevalência da justiça do resultado nos questionários deste estudo, de maneira geral observou-se que a maioria dos participantes utilizou o espaço opcional “justificativa”, havendo referências à busca da verdade real como princípio a nortear a decisão, à instrumentalidade do processo e muitas vezes ao fato de os princípios, em geral, também integrarem o Direito. Desse modo, como foram muitas as justificativas remetendo aos princípios, embora não tenha sido nosso objetivo inicial o de apurar o conceito de Estado de Direito adotado pelos juízes, as anotações dos participantes indicam que suas concepções mais se aproximam da formulação substantiva, sendo condizentes com os experimentos realizados com cidadãos não integrantes do Judiciário.

Embora esse não tenha sido o objeto de estudo específico da pesquisa 
realizada por Vianna, Carvalho, Melo e Burgos ${ }^{123}$, conclusão parecida pode ser extraída dos resultados obtidos pelos autores, já que 83\% dos magistrados (num total de 3927 juízes participantes do estudo) concordou com a assertiva de que $O$ Poder Judiciário não é neutro; em suas decisões o magistrado deve interpretar a lei no sentido de aproximá-la dos processos sociais substantivos e, assim, influir na mudança social. Isso em detrimento da outra alternativa: A não neutralidade do Judiciário ameaça as liberdades e a mudança social não deve ser objeto de apreciação por parte desse poder.

Conclui-se, portanto, que há indícios fortes de que o conceito de Estado de Direito dos juízes segue a formulação substantiva e, no que se refere à prática decisória, esta tende para o particularismo, não para o formalismo. As razões de substância ou argumentos práticos puros prevalecem tanto em abstrato como em concreto.

Por fim, o paradoxo abstrato/concreto, ao ser constatado, não ratificou a hipótese NBAR. Segundo essa teoria, como visto, existe uma crença de que, quando as expectativas humanas são frustradas (norm broken), um agente deve ser responsabilizado (agent responsible). E, como é mais evidente a violação de uma norma (ou quebra de expectativa) num caso concreto que num abstrato, espera-se que a dissonância (contradição entre o que se crê e o que de fato ocorreu) seja maior na situação concreta. Ela se resolve por meio de uma responsabilização mais forte do agente. Ou seja: a violação de uma regra é mais evidente num caso concreto que num abstrato e gera uma resposta mais firme no sentido de reparar tal violação.

No questionário aplicado aos juízes, deveria ser evidente que a violação à regra em uma situação concreta geraria maior dissonância e, por isso, seria evitada. Só que a opção pela regra legal (e pela realização das expectativas) foi maior em abstrato que em concreto. Desse modo, não se pode dizer que houve maior dissonância em concreto. O agente não foi “responsabilizado” mais em concreto: na verdade, não se aplicou a revelia na maior parte das respostas (deixando-se de “responsabilizar” o agente por ter faltado à audiência). Também não houve uma responsabilização maior no caso da doméstica, pois somente uma

\footnotetext{
${ }^{123}$ Op. cit., 1996.
} 
das respostas optou por condenar a ex-empregadora ao pagamento das verbas rescisórias. 


\section{5}

\section{Conclusão}

No conflito entre o que dispõe a regra jurídica e o que o juiz considera justo, qual a opção do magistrado quando decide um caso concreto? Essa opção é a mesma que ele faz quando indagado em abstrato, se em caso de conflito prevalece em suas decisões a norma legal ou a justiça do resultado? Sob essa questão se debruçou o presente estudo. Para respondê-la, tomou-se como referência metodológica os estudos empíricos analisados por Knobe e outros ${ }^{124}$ e como base da investigação um trabalho anterior realizado por Schweitzer e outros ${ }^{125}$, em que se formulou um experimento para saber como particulares avaliavam a atuação de uma autoridade que, para garantir um resultado justo, decidia descumprir uma regra.

Descobriu-se que os cidadãos entendem, em sua maioria, apropriada tal decisão, exceto quando realizada no âmbito de um jogo de basebol, por um árbitro. Os resultados indicaram, portanto, que a concepção da população sobre o Estado de Direito se aproxima da formulação substantiva, incluindo questões de justiça e moralidade. Assim, seria considerada legítima a decisão que se atém à justiça do resultado, não estritamente às regras.

Para realizar o estudo empírico no âmbito da magistratura, selecionou-se um caso referência, o da primeira instância da Justiça do Trabalho da Primeira Região. Além disso, foram enunciados os principais conceitos de Estado de Direito, tomando-se como referencial teórico os estudos de Tamanaha, que subdivide as concepções em formais e substantivas, cada concepção subsequente agregando outros elementos aos já aduzidos pelas anteriores. As primeiras são aquelas que incluem no conceito apenas questões procedimentais, como o fato de as regras se originarem de uma autoridade soberana (Direito pelo Estado), de serem genéricas, prospectivas, claras, públicas e relativamente estáveis (legalidade

\footnotetext{
${ }^{124}$ KNOBE, Joshua \& DORIS, John M. Strawsonian variations: folk morality and the search for a unified theory. In The handbook of moral psichology. Oxford: Oxford University Press, 2007. Disponível em <http://www.unc.edu/ knobe/Knobe-Doris.pdf >. Acessado em: 04.03.2013.

${ }^{125}$ SCHWEITZER, N. J.; SYLVESTER, Douglas J. e SAKS, Michael J. Rule violations and the rule of law: a factorial survey of public attitudes. Disponível em

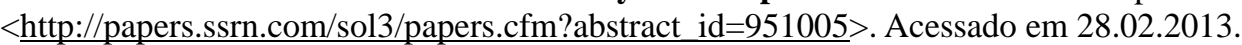

SCHWEITZER, N. J.; SAKS, Michael J. e LOVIS-MCMAHON, David. Is the rule of law a law of rules? Judgments of rule of law violations. Disponível em $<$ http://papers.ssrn.com/sol3/papers.cfm?abstract_id=1439055>. Acessado em 28.02.2013.
} 
formal) e de, além de tudo isso, serem aprovadas por meio de um processo democrático (correntes democráticas). As concepções substantivas incluem, além desses fatores, os direitos individuais e, dependendo da vertente, até mesmo os direitos sociais.

A partir dessas referências conceituais, observou-se que a formulação substantiva, para a qual tenderam os cidadãos que participaram do experimento já mencionado, potencialmente legitima decisões judiciais particularistas, ou seja, aquelas que se pautam pela busca do melhor resultado possível para cada caso que possa aparecer, de acordo com a justificação da regra ou com outras razões pertinentes. Tanto que, em geral, foi considerada apropriada a decisão da autoridade de descumprir uma regra para garantir um resultado justo.

Nas decisões particularistas, prevalecem, em regra, os argumentos morais, não os de autoridade. Isso porque, para se superar uma lei clara, há necessidade de se utilizar razões consequencialistas ou deontológicas, sendo as primeiras aquelas que dizem respeito às consequências de determinada conduta para aferir se ela deve ou não ser realizada. As segundas são aquelas concernentes ao valor inerente de determinada conduta, se é certa ou errada, se é justa ou injusta, independente das consequências.

Com base, pois, na constatação de que a concepção de Estado de Direito substantivo supõe-se preponderante na sociedade e de que essa visão considera legítimas decisões particularistas que recorrem, em regra, a argumentos morais, passou-se à análise do contexto em que se inserem as decisões judiciais no caso referência. Hart, ao criticar as posturas extremas do realismo jurídico e do formalismo, demonstrou que a atividade judicante não se baseia exclusivamente em critérios extrajurídicos nem se pauta apenas por um processo lógico de subsunção decorrente da invocação de um argumento de autoridade. Ora há situações em que acaba havendo escolha por parte do juiz, ora há uma simples aplicação de regras jurídicas claras. Na Justiça do Trabalho, são muitas as situações em que se percebe não ser possível uma simples subsunção sem o ingresso de dados valorativos, como por exemplo, para resolver um problema de lacuna; para a própria compreensão do enunciado legal quando há conceitos com grau pequeno de determinação; para definição dos fatos relevantes; para, no conflito entre regras, escolher qual deve ser aplicada, garantindo a coerência do sistema jurídico; para resolver conflitos entre princípios em caso de inexistir regra 
clara; para dar uma resposta à parte que traz um argumento de substância.

Assim, o contexto em que atuam os magistrados trabalhistas fluminenses é marcado por diversos casos em que são necessárias análises morais, de substância. Em que pese tal cenário de diversas situações de escolha fundamentada em razões morais por parte do juiz, no conjunto de regras claras existentes no Direito do Trabalho também é possível identificar casos de sobreinclusão e de subinclusão, ou seja, aqueles que comportam dois tipos de solução: uma decorrente de uma simples subsunção da situação concreta à regra (com utilização de argumentos de autoridade), outra decorrente da justiça do resultado, superando-se a regra em prol de uma solução que preserve a finalidade para a qual foi criada a norma (argumentos morais).

Observe-se que não se trata de a regra possuir termos vagos, mas sim de haver um enunciado claro, que incide sobre determinada situação, mas que, se aplicado, não realiza a finalidade para o qual foi criado. Nesse caso, a regra diz mais do que deveria ou menos, porque diante daquele caso concreto, ela não obsta o mal nem garante o bem pretendido. Nessas situações prevaleceria, sob a ótica dos cidadãos participantes da pesquisa parâmetro da hipótese do presente estudo, a justiça do resultado. Então, para analisar a perspectiva dos juízes frente a um caso de sobreinclusão ou subinclusão, foi utilizado um questionário, submetido pela pesquisadora diretamente aos juízes fluminenses, em papel ou mensagem eletrônica.

Explorou-se o paradoxo abstrato/concreto: a alguns participantes foi indagada uma questão abstrata, a outros uma concreta. A amostra levou em consideração o tempo de exercício da função, o gênero, a idade, a orientação política, o grau de instrução do magistrado e de seus pais, além da circunstância de lecionarem ou não.

Partindo-se dos modelos formalista e particularista - sendo importante ressaltar que nesse caso o conceito de formalismo é aquele dado e defendido por Schauer, não o criticado por Hart - concluiu-se que os juízes, em geral, tendem menos ao formalismo que ao particularismo, dando prevalência ao “justo" em detrimento do "legal", mesmo quando indagados em tese. Houve prevalência da opção pela justiça do resultado (57,97\% dos participantes), com remição aos argumentos morais em $85,51 \%$ das respostas, já que a escolha por nenhuma das 
duas opções (formalista ou particularista) ou por ambas foi acompanhada invariavelmente de razões de substância, consequencialistas ou deontológicas. A opção pelos argumentos jurídicos ou de autoridade (que remetem a uma regra ou entendimento jurisprudencial consolidado) foi pequena $(14,49 \%)$.

Concretamente os juízes se mostraram mais particularistas, confirmando a disparidade nas respostas quando a pergunta é realizada em abstrato e em concreto, no chamado paradoxo abstrato/concreto. Como vimos, não há consenso na doutrina das razões para tanto, havendo quem defenda que essa diferença decorre de fatores afetivos e quem diga que provém de fatores congnitivos. Entretanto, supõe-se que não é só um fator específico o responsável pela divergência nas respostas, seguindo-se, no presente estudo, a linha das teorias variantes.

Observou-se nas respostas, ainda, referência à busca da verdade real como princípio a nortear a decisão, à instrumentalidade do processo e muitas vezes ao fato de os princípios, em geral, também integrarem o Direito. Assim sendo, diante das muitas as justificativas remetendo aos princípios, as anotações dos participantes indicam que suas concepções mais se aproximam da formulação substantiva, sendo condizentes com os experimentos realizados com cidadãos não integrantes do Judiciário.

Diante disso, no caso referência da primeira instância do Tribunal Regional do Trabalho da Primeira Região, há indícios fortes de que o conceito de Estado de Direito dos juízes segue a formulação substantiva e, no que se refere à prática decisória, esta tende para o particularismo, não para o formalismo. As razões de substância ou argumentos morais prevalecem tanto em abstrato como em concreto. Os resultados obtidos foram congruentes com aqueles dos experimentos realizados com pessoas não integrantes do Judiciário, indicando que a atuação dos magistrados tem sido condizente com o que a sociedade deles espera. 
6

\section{Referências Bibliográficas}

APPIAH, K. A. Identidad, autenticidad, supervivencia. Sociedades multiculturales y reproducción social. In El multiculturalismoy 'la política del reconocimiento'. $2^{\mathrm{a}}$ ed. México: Fondo de Cultura Econômica, 2009, pp. 213-232.

O código de honra: como ocorrem as revoluções morais. Tradução Denise Bottmann. São Paulo: Companhia das Letras, 2012.

ARGUELHES, D. W.; LEAL, F. Pragmatismo como (Meta) Teoria Normativa da Decisão Judicial: Caracterização. Estratégias e implicações. Filosofia e Teoria Constitucional Contemporânea. SARMENTO, Daniel (coord.). Rio de Janeiro: Lumen Juris. 2009.

ARPALY, N. e SCHROEDER, T. Praise, blame and the whole self. In Philosophical studies 93: 161-188, 1999.

ÁVILA, H. Teoria dos Princípios: da Definição à Aplicação dos Princípios Jurídicos. $8^{\mathrm{a}}$ ed. São Paulo: Malheiros Editores: 2008.

BALANDIER, G. O contorno: poder e modernidade. Tradução Suzana Martins. Rio de Janeiro: Bertrand Brasil, 1997.

BARROSO, L. R. A Reconstrução Democrática do Direito Público no Brasil. In A Reconstrução Democrática do Direito Público no Brasil/ Luís Roberto Barroso (org.). - Rio de Janeiro: Renovar, 2007, pp. 34-39.

. Constituição, democracia e supremacia Judicial: Direito e política no Brasil contemporâneo. In Revista da Faculdade de Direito - UERJ, v. 2, n. 21, jan./jun. 2012, p. 04. Disponível em <http://www.oab.org.br/editora/revista/revista_11/artigos/constituicaodemocrac iaesupremaciajudicial.pdf $>$. Acessado em 05.02.2014.

BOBBIO, N. Teoria do Ordenamento Jurídico. Tradução Maria Celeste C. J. Santos; rev. téc. Claudio De Cicco; apres. Tércio Sampaio Ferraz Júnior. 10a ed. Brasília: Editora Universidade de Brasília, 1997.

CANARIS, C. W. Pensamento Sistemático e Conceito de Sistema na Ciência do Direito. Tradução de Antônio Menezes Cordeiro. Lisboa: Fundação Calouste Gulbenkian, 1989.

CAVALLAZZI, R. L; D’OLIVEIRA, S. A. L. C. Práticas Sociais Instituintes e a sua Tradução Jurídica Urbanística. In Direito em Revista: 20 anos de pesquisa. FONSECA, Maria Guadalupe Piragibe da; CAVALLAZZI, Rosângela Lunardelli (Org.). Rio de Janeiro: Letra Capital, OAB/RJ e UNIGRANRIO, 2004. 
COONS, J. E. e BRENNAN, P. By nature equal: the anatomy of a western insight. New Jersey: Pinceton University Press, 1999.

DE WAAL, F.. A era da empatia: lições da natureza para uma sociedade mais gentil. Tradução Rejane Rubino. São Paulo: Companhia das Letras, 2010.

DWORKIN, R. Constitucionalismo e democracia. Texto traduzido para fins acadêmicos por Emílio Peluso Neder Meyer. [S.l.:s.n.,2013?]. Publicado originalmente no European Journal of Philosophy, nº 3:1, p. 2-11, em 1995.

Levando os direitos a sério. Tradução Nelson Boeira. São Paulo: Martins Fontes, 2002

FRASER, N. Reenquadrando a justiça em um mundo globalizado. Tradução Ana Carolina Freitas Lima Ogando e Mariana Prandini Fraga Assis. Revista Lua Nova. São Paulo, n. 77, 2009, pp. 11-39.

FREUD, S. O mal-estar na civilização. Tradução Paulo César de Souza. São Paulo: Penguin Classics Companhia das Letras, 2011.

FULLER, L. L. The morality of law. $2^{\text {a }}$ edição revista. New Haven: Yale University Press, 1969.

GRAY, K.; KNOBE, J.; SHESKIN, M.; BLOOM, P.; BARRETT, L. F. More than a body: mind perception and the nature of objectification, 2011. Disponível em:

<http://www.mpm.umd.edu/Gray,\%20Knobe,\%20Sheskin,\%20Bloom\%2 0\&\%20Barrett.\%20(in\%20press).\%200bjectification.pdf $>$. Acessado em: 13.11.2012.

HABERMAS, J. Between facts and norms. Contributions to a discourse theory of law and democracy. Translated by William Rehg. Massachusetts: The MIT Press, 1996, Capítulos 7 e 8.

HART, H. L. A. A teoria do direito norte-americana pelos olhos ingleses: o pesadelo e o nobre sonho. In Ensaios sobre Teoria do Direito e Filosofia. Coleção teoria e filosofia do direito. Ronaldo Porto Macedo, coord. São Paulo: Campus Jurídico, 1983, pp. 137-161.

O conceito de Direito. $3^{a}$ ed. Tradução de A. Ribeiro Mendes. Lisboa: Fundação Calouste Gulbenkian, 2001.

HAYEK, F. A. Law, legislation and liberty. A new statement of the liberal principles of justice and political economy. Londres: Routledge, 1998. Volume 3. pp. 98-104.

KNOBE, J. e DORIS, J. M. Strawsonian variations: folk morality and the search for a unified theory. In The handbook of moral psichology. Oxford: Oxford University Press, 2007. Disponível em 


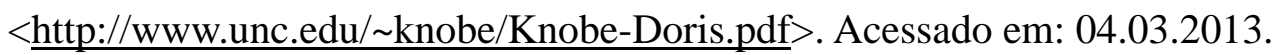

KNOBE, N. Free will and the bounds of the self. In The Oxford handbook of free will. 2a ed. Robert Kane, coord. Oxford: Oxford University Press, 2011.

MANDELBAUM, E. e RIPLEY, D. Explaining the abstract/concrete paradoxes in moral psychology: the NBAR hypothesis. Disponível em $<$ http://people.fas.harvard.edu/ mandelbaum/NBAR\%20published\%20Author s\%20copy.pdf $>$. Acessado em 28.02.2013.

LERNER, J. S., GOLDBERG, J. H. e TETLOCK, P. E. Sober second thought: the effects of accountability, anger and authoritarianism on attributions of responsibility. In Personality and social Psychology Bulletin. 1998; 24:563574. Disponível em <http://numerons.files.wordpress.com/2012/04/08attributions-of-responsibility.pdf $>$. Acessado em 05.02.2014.

MACINTYRE, A. After virtue. Notre Dame: Notre Dame University Press, 1984.

MAXIMILIANO, C. Hermenêutica e Aplicação do Direito. 9a ed. $3^{\mathrm{a}}$ tiragem. Rio de Janeiro: Forense, 1984

MENDES, C. H. Direitos fundamentais, separação de poderes e deliberação. São Paulo: Saraiva, 2011.

PEREIRA, C. M. da S. Instituições de Direito Civil. 19a ed. Vol. I. Rio de Janeiro: Editora Forense, 1998.

PINHEIRO, A. C. Judiciário, reforma e economia: a visão dos magistrados. p. $40 . \quad$ Disponível em $<\underline{\text { http://www.febraban.org.br/Arquivo/Destaques/armando_castelar_pinheiro2. }}$ pdf $>$. Acessado em 07.02.2014.

PLASTINO, C. A. A psicanálise e a questão do paradigma. In O primado da afetividade, Rio de Janeiro: Relume Dumará, 2001.

PRINZ, J. Contra a empatia. Disponível em < a-empatia/> . Acessado em: 04.01.2013.

RAWLS, J. Justiça como Eqüidade: uma concepção política, não metafísica. In Lua Nova, Revista de Cultura e Política, n. 25, 1992.

RAZ, J. The rule of law and its virtue. In The authority of law. Oxford: Clarendon Press, 1979.

RIGOBON, R. e RODRIK, D. Rule of law, democracy, openness, and income. Estimating the interrelationships. In Economics of Transition, 2005, pp. 533564. Disponível em <http://www.nber.org/papers/w10750.pdf> $>$. Acessado em 12.01.2014. 
ROSE, J. The rule of law in the western world: an overview. Disponível em $<$ http://papers.ssrn.com/sol3/papers.cfm?abstract_id=1426343 > acessado em 06.05.2013.

RUIZ, C. M. M. B. A justiça perante uma crítica ética da violência. In Justiça e memória: para uma crítica ética da violência. RUIZ, Castor M. M. Bartolomé (organizador). Unisinos, p. 108.

SADEK, M. T. A crise do judiciário vista pelos juízes: resultados da pesquisa quantitativa. In Uma introdução ao estudo da justiça. M. T. Sadek (org.). Editora Sumaré, $1995 . \quad$ Disponível em $<$ http://pt.scribd.com/doc/57833300/SADEK-Uma-Introducao-Ao-Estudo-DaJustica $>$. Acessado em 03.02.2014.

Magistrados Brasileiros: caracterização e opiniões. Disponível em <http://www.amb.com.br/portal/docs/pesquisa/PesquisaAMB2005.pdf > acessado em 22.10.2013.

Pesquisa AMB 2006. A palavra está com você. Resultados. Disponível em <http://www.amb.com.br/portal/docs/pesquisa2006.pdf $>$. Acessado em 05.02.2014.

SANTOS, B. de S. Um discurso sobre as ciências. $7^{\text {a }}$ ed. São Paulo: Cortez Editora, 2011.

SCHAUER, F. Playing by the rules: a philosophical examination of rule-based decision-making in law and in life. Clarendon law series. Oxford: Oxford University Press, 2002.

Thinking like a lawyer: a new introduction to legal reasoning. Londres: Harvard University Press, 2009.

SCHWEITZER, N. J.; SYLVESTER, D. J. e SAKS, M. Rule violations and the rule of law: a factorial survey of public attitudes. Disponível em $<$ http://papers.ssrn.com/sol3/papers.cfm?abstract_id=951005 $>$. Acessado em 28.02.2013.

SCHWEITZER, N. J.; SAKS, M. J. e LOVIS-MCMAHON, D. Is the rule of law a law of rules? Judgments of rule of law violations. Disponível em $<$ http://papers.ssrn.com/sol3/papers.cfm?abstract_id=1439055 $>$. Acessado em 28.02.2013.

SINNOT-ARMSTRONG, W. Abstract + Concrete $=$ Paradox. In Experimental Philosophy (J. Knobe e S. Nichols, coord.). Nova Iorque: Oxford University Press, 2008.

SKITKA, L. J. e MULLEN, E. Understanding judgments of fairness in a realworld political context: a test of the value protection model of justice reasoning. University of Illinois at Chicago, 2002. Disponível em

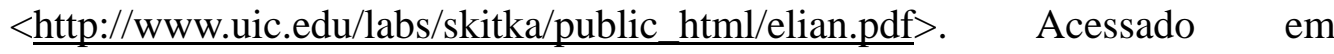


03.02.2014.

SKITKA, L. e HOUSTON, D. When due process is of no consequence: Moral mandates and presumed defendant guilt or innocence. 14 (3) Soc. Just. Res. 305 (2001). Disponível em <http://link.springer.com/article/10.1023\%2FA\%3A1014372008257>. Acessado em 03.02.2014.

SLOVIC, P. If I look at the mass I will never act: psychic numbing and genocide. Judgement and decision making, vol. 2, $\mathrm{n}^{\circ}$ 2, Abril 2007, pp. 79-95.

STRUCHINER, N. Algumas 'proposições fulcrais' acerca do direito: o debate jusnaturalismo vs. juspositivismo. In Perspectivas atuais da filosofia do direito. Antonio Cavalcanti Maia, Carolina de Campos Melo, Gisele Cittadino, Thamy Pogrebinschi organizadores. Rio de Janeiro: Lumen Iuris, 2005.

Just say no to empathy: making the case for autistic decisionmaking. Disponível em <http://www.udg.edu/LinkClick.aspx?fileticket=I2m6LuIGSo\%3D\&tabid=9724\&language=ca-ES $>$. Acessado em: 28.12.2012.

O direito como um campo de escolhas: por uma leitura das regras prescritivas como relações. In Nas fronteiras do formalismo: a função social da dogmática jurídica hoje. RODRIGUES, José Rodrigo; DA SILVA E COSTA, Carlos Eduardo Batalha e BARBOSA, Samuel Rodrigues, organizadores. Rio de Janeiro: Editora Saraiva, 2009.

STRUCHINER, N. e SHECAIRA, F. P. A distinção entre direito e moral e a distinção moral do direito. In RDE Revista de Direito do Estado. Ano 7, n ${ }^{\circ}$ 22. Rio de Janeiro: Renovar, jan/mar 2012, pp.131-145.

STRUCHINER, N. e SHECAIRA, F. P. Verbete Realismo jurídico. Dicionário de teoria e filosofia do direito. Alexandre Travessoni, coordenador geral. São Paulo: LTr, 2011, pp. 348-351.

SYTSMA, J. e MACHERY, E. The two sources of moral standing, 2012. Disponível em: <http://philsci-archive.pitt.edu/9130/>. Acessado em: 13.11.2012.

TAMANAHA, B. Z. On the rule of law: history, politics theory. Nova Iorque: Cambridge University Press, 2004.

VIANNA, L. W. et al. Corpo e alma da magistratura brasileira. Rio de Janeiro: Editora Revan, 1997.

WARAT, L.A. e RUSSO, A. E. Interpretación de Ia Ley. Buenos Aires: Abeledo-Perrot, 1987.

WINNICOTT, D. W. A família e o desenvolvimento individual. Tradução Marcelo Brandão Cipolla. 4a ed. São Paulo: Martins Fontes, 2011. 
O ambiente e os processos de maturação: estudos sobre a teoria do desenvolvimento emocional. Trad. Irineo Constantino Schuch Ortiz. Porto Alegre: Artmed, 1983. 


\section{Apêndice}

\section{Termo de consentimento}

Declaro consentir em participar da pesquisa realizada no âmbito do Tribunal Regional da Primeira Região pela Juíza do Trabalho Helen Marques Peixoto, sob orientação dos Professores Doutores Noel Struchiner e Rosângela Lunardelli Cavallazzi, aos quais poderei consultar a qualquer momento que julgar necessário, por meio do telefone (21) 8722-1135 ou e-mail helen.m.peixoto@gmail.com.

Afirmo que aceitei participar por minha própria vontade, sem receber qualquer incentivo financeiro ou ter qualquer ônus e com a finalidade exclusiva de colaborar para o sucesso da pesquisa. Fui informado(a) dos objetivos estritamente acadêmicos do estudo, que, em linhas gerais, é investigar a tomada de decisão jurídica.

Minha colaboração se fará de forma anônima, por meio de questionário. O acesso e a análise dos dados coletados se farão apenas pelo(a) pesquisador(a) e/ou seu(s) orientador(es) / coordenador(es).

Fui ainda informado(a) de que posso me retirar desse estudo a qualquer momento, sem sofrer quaisquer sanções ou constrangimentos.

Pedimos encarecidamente para que não comente sobre os procedimentos deste estudo com outros potenciais participantes até o encerramento da coleta de dados (dezembro/2013), pois isto poderia afetar os resultados da pesquisa.

Rio de Janeiro, de de 2013.

Nome do(a) participante:

Assinatura do(a) participante: 


\section{Questionário}

Informações demográficas, sociais e econômicas:

O(a) Senhor(a) é:

( ) juiz de primeira instância ～～～desembargador

Quanto tempo V. Exa. está na atividade judicante?

( ) menos de 5 anos ( ) de 5 a 10 anos

( ) de 10 a 15 anos ( ) mais de 15 anos

Idade: anos

sexo: ( ) masculino ( ) feminino

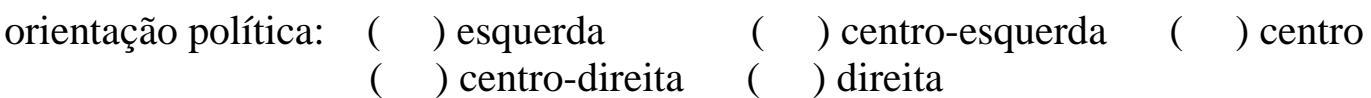

grau de instrução: ( ) superior completo

( ) mestrado incompleto

( ) pós-graduado

( ) doutorado incompleto

( ) mestrado completo

( ) pós-doutorado incompleto ( ) pós-doutorado completo

Atividades acadêmicas: ( ) não leciona ( ) leciona em faculdade

Escola de Magistratura

( ) leciona em cursos preparatórios ( ) leciona em

( ) leciona em outras instituições

grau de instrução do pai: ( ) sem instrução ( ) $1^{\circ}$ grau incompleto

( ) $1^{\circ}$ grau completo

( ) $2^{\circ}$ grau incompleto ( ) $2^{\circ}$ grau completo

( ) superior incompleto ( ) superior completo

grau de instrução da mãe: ( ) sem instrução ( ) $1^{\circ}$ grau incompleto

( ) $1^{\circ}$ grau completo ( ) $2^{\circ}$ grau incompleto

( ) $2^{\circ}$ grau completo ( ) superior incompleto

( ) superior completo

Ficamos gratos pela sua colaboração! 


\section{Questionário}

Em determinado caso pendente de decisão, a regra legal aplicável geraria um resultado injusto, segundo seu ponto de vista. o(a) Senhor(a) optaria:

( ) pelo resultado justo ( ) pela aplicação da regra legal

Justificativa (opcional): 


\section{Questionário}

Numa relação de trabalho doméstico, Maria estava furtando dinheiro de sua empregadora, Fátima. Chegou a furtar mais de R\$ 5.000,00. Dispensada, Maria ajuizou reclamação trabalhista requerendo as verbas rescisórias decorrentes da dispensa sem justa causa, pois considerava que Fátima não poderia comprovar o furto.

A reclamada, Fátima, alegou justa causa para a demissão, afirmando que a reclamante estava furtando dinheiro de sua residência e juntou como prova de suas alegações uma carta escrita por Maria e que seria enviada a uma amiga. Na carta, Maria afirmava que "estou conseguindo roubar um bom dinheiro da patroa e em breve vou poder pagar o empréstimo que te devo. Fique tranquila porque ela nem desconfia! Estou pegando aos poucos e sem deixar rastro".

A reclamante alegou a ilicitude da prova, que foi reconhecida e declarada incidentalmente pelo juízo, pois a ex-empregadora violou o sigilo de correspondência. Não foi esclarecido como a empregadora teve acesso à carta. Observe-se que a correspondência é a única prova do furto.

Diante disso, o(a) Senhor(a).

( optaria pela aplicação da regra da proibição da prova ilícita, julgando procedente o pedido de verbas rescisórias.

( ) optaria pela justiça do resultado, julgando improcedente o pedido de verbas rescisórias, visto que a justa causa de fato ocorreu.

outro:

Justificativa (opcional): 


\section{Questionário}

Numa relação de emprego, a empregadora Vendas de Roupas Ltda dispensou Amanda, sua empregada, sem justa causa. Pagou todas as verbas rescisórias.

Após, Amanda ajuizou reclamação trabalhista, alegando que fazia jus a horas extras e que foi dispensada sem nada receber a título de verbas rescisórias. $\mathrm{Na}$ audiência inaugural, a representante da empresa chegou quinze minutos atrasada, quando a reclamante e seu patrono já tinham se retirado.

Peticionou o patrono da empresa, sustentando que o atraso foi de apenas quinze minutos e que ocorreu em virtude de a sócia principal da empresa estar acompanhando seu pai, que se encontrava internado no hospital. Afirmou ainda que as verbas rescisórias foram pagas. Juntou documentos que comprovavam todas as alegações. Entretanto, a Súmula 122 do TST exige, para elidir a revelia, a apresentação de atestado médico do próprio representante da pessoa jurídica, não de seu pai, e que o atestado informe a impossibilidade de locomoção no dia da audiência, o que não ocorreu no caso em tela.

Diante disso, o(a) Senhor(a).

( ) aplicaria a revelia, condenando a empresa inclusive ao pagamento das verbas rescisórias que já haviam sido pagas, porque o atestado não preenche os requisitos exigidos pela Súmula 122, TST, e estava preclusa a produção da prova documental quando de sua apresentação.

( ) não aplicaria a revelia.

outro:

Justificativa (opcional): 